Portland State University

PDXScholar

Environmental Science and Management

Professional Master's Project Reports

Spring 2012

\title{
A Performance Assessment of Two Multi- component Water Quality Facilities in the Columbia Slough and Fairview Creek Watersheds
}

Chris Robinson

Portland State University

Follow this and additional works at: https://pdxscholar.library.pdx.edu/mem_gradprojects

Part of the Water Resource Management Commons

Let us know how access to this document benefits you.

\section{Recommended Citation}

Robinson, Chris, "A Performance Assessment of Two Multi-component Water Quality Facilities in the Columbia Slough and Fairview Creek Watersheds" (2012). Environmental Science and Management Professional Master's Project Reports. 23.

https://pdxscholar.library.pdx.edu/mem_gradprojects/23

https://doi.org/10.15760/mem.17

This Project is brought to you for free and open access. It has been accepted for inclusion in Environmental Science and Management Professional Master's Project Reports by an authorized administrator of PDXScholar. Please contact us if we can make this document more accessible: pdxscholar@pdx.edu. 


\section{Abstract}

Title: A Performance Assessment of Two Multi-component Stormwater Management Facilities in the Columbia Slough and Fairview Creek Watersheds

We examined the treatment trains at the Columbia Slough (CSWQF) and Fairview Creek Water Quality Facilities (FCWQF) in Gresham, OR and assessed their effectiveness at removing pollutants including nutrients, TSS, metals, pesticides, PAHs, and VOCs. Time-paced, fixed volume composite samples were collected during storm events at the inlets and outlet of the CSWQF and at the inlets and outlet of each treatment train component of the FCWQF. In addition, long-term data collected at the FCWQF was analyzed. Composite data collected during November 2-3, 2011 and March 5-6, 2012 showed that the treatment trains can measurably reduce the event mean concentration (EMC) of most pollutants present in stormwater. Removal efficiencies ranged from a low of 11 to 34 percent for nutrients to a high of 58 to 70 percent for TSS. Long-term data from the FCWQF confirms the findings of the individual sampling events and demonstrates that the FCWQF treatment train significantly reduces the EMCs of $\mathrm{NH}_{3}-\mathrm{N}$, $\mathrm{TKN}, \mathrm{BOD}_{5}$, most of the heavy metals tested for, bacteria, TSS, and turbidity. When compared to data available from the International Stormwater BMP Database, effluent concentrations at the FCWQF were comparable to or lower than those in the BMP Database for nutrients including TKN, OP, and TP; metals including $\mathrm{DCu}, \mathrm{TCu}, \mathrm{TNi}, \mathrm{DPb}$, and TPb; and TSS. Effluent concentrations at the FCWQF were higher than those in the BMP Database for DZn, TZn, turbidity, and bacteria. When comparing the two facilities, the FCWQF generally reduced pollutant concentrations to a greater degree than did the CSWQF. Pollutant removal efficiency was potentially limited by rainfall intensity and seasonal factors, with removal efficiencies being higher for the spring event than the fall event. It is recommended that longterm monitoring be continued at both facilities until the pollutant removal efficiency of the entire CSWQF and the FCWQF treatment train components can be statistically quantified. Changes in sample collection methods and flow measurement are recommended that could improve the accuracy of pollutant concentration estimates considerably. Finally, it is recommended that further research be conducted to determine if significant relationships can be established between particle size and the following pollutants: heavy metals, total phosphorus, and PAHs. Defining these relationships may make it possible to estimate pollutant concentrations using the stormwater particle size distribution analysis. 
This page left blank intentionally. 
A Performance Assessment of Two Multi-component Water Quality Facilities in the Columbia Slough and Fairview Creek Watersheds

\author{
Prepared for: \\ City of Gresham \\ Department of Environmental Services \\ 1333 NW Eastman Parkway \\ Gresham, OR 97030 \\ Prepared by: \\ Chris Robinson \\ Advised by Dr. Joseph Maser \\ Portland State University \\ Department of Environmental Science \& Management \\ Portland, OR 97201
}

June 2012

\title{
Portland State

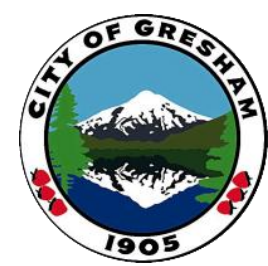




\section{Acknowledgements}

I would like to thank Dr. Joseph Maser for acting as advisor on this project and Dr. Gene Foster for his contributions towards the completion of this project. I would especially like to thank Torrey Lindbo of the City of Gresham's Department of Environmental Services for helping to coordinate project activities and providing valuable technical advice and guidance. Additionally, I would like to thank the Department of Environmental Services for providing access to their facilities and for the funding that was so necessary to analyze water samples at the scale of this project. 


\section{Contents}

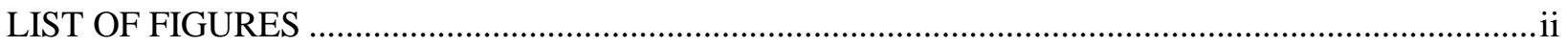

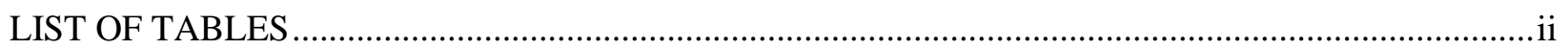

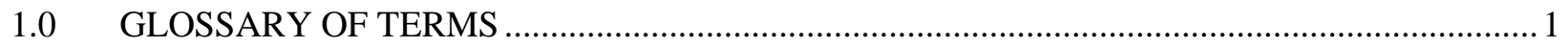

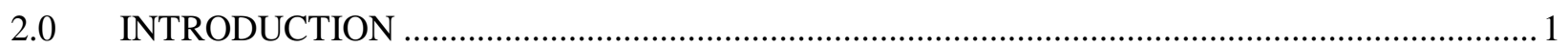

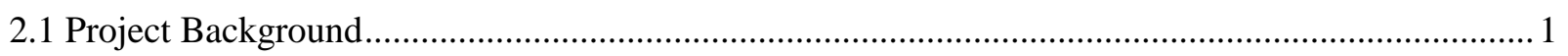

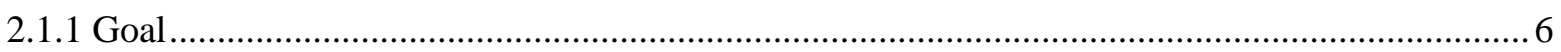

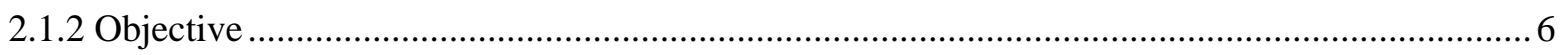

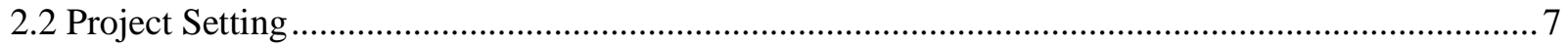

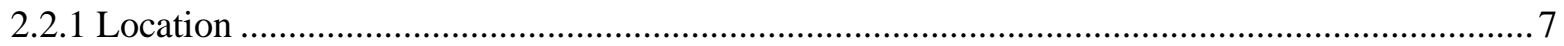

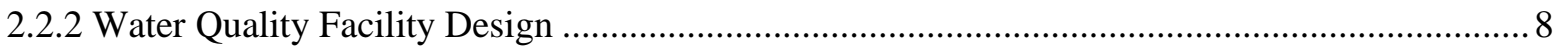

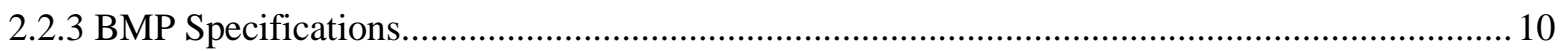

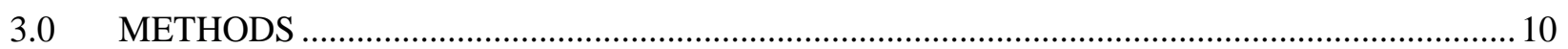

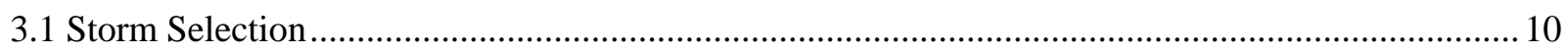

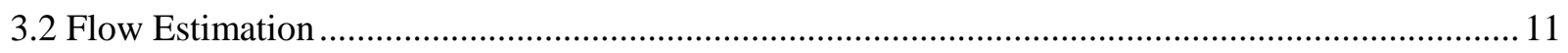

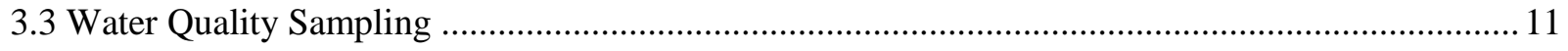

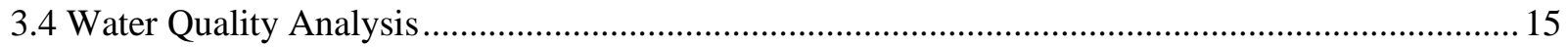

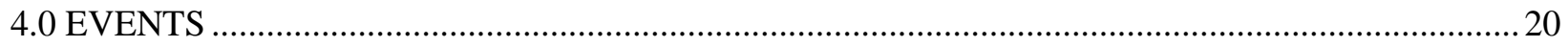

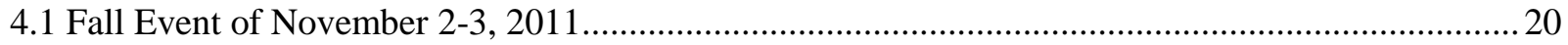

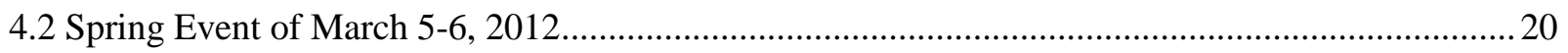

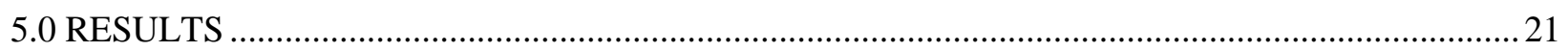

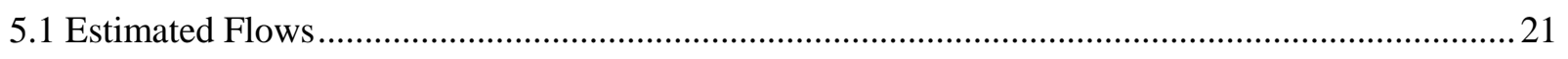

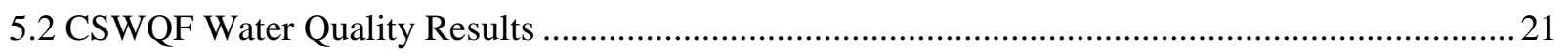

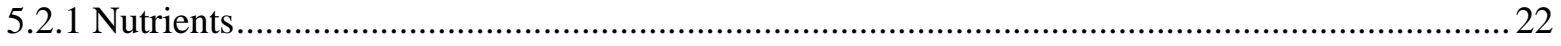

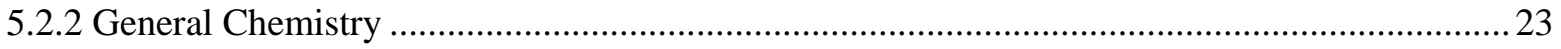

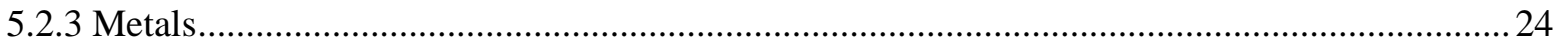

5.2.4 Chlorinated Herbicides, Organochlorine Pesticides, Phthalates, PAHs, and VOCs .................26

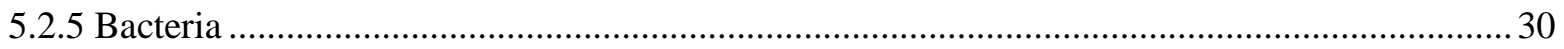

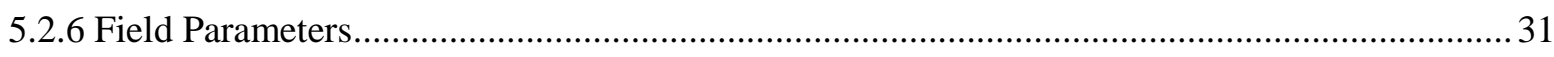

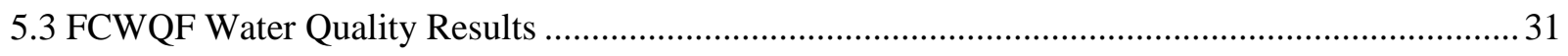

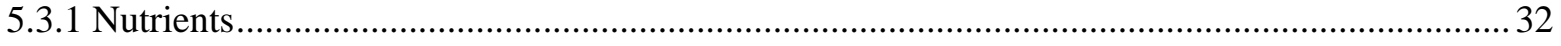

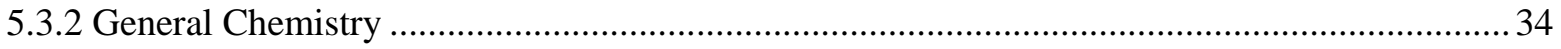




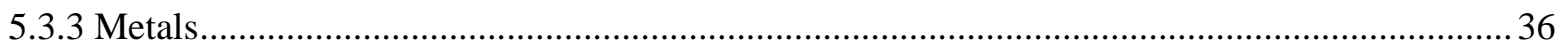

5.3.4 Chlorinated Herbicides, Organochlorine Pesticides, Phthalates, PAHs, and VOCs ..................42

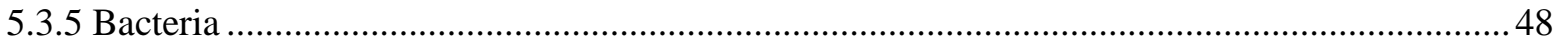

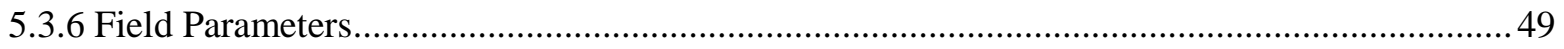

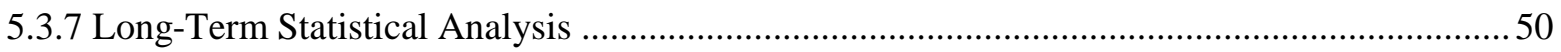

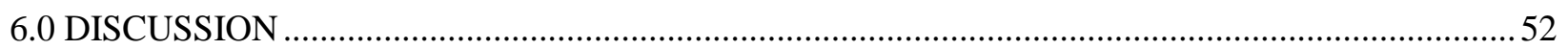

6.1 Comparison of Long-term and Event-based Results at the FCWQF ............................................52

6.2 Comparison of Treatment Train Removal Efficiencies .............................................................61

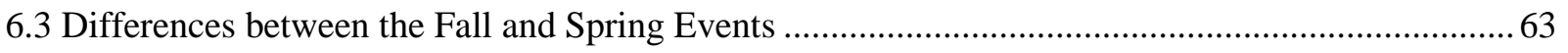

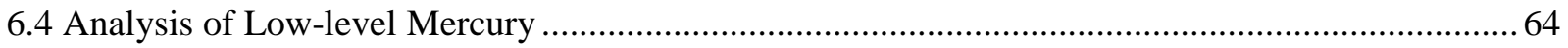

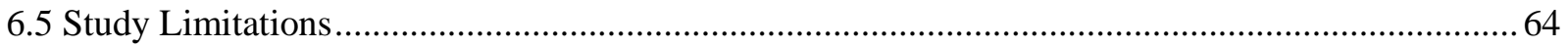

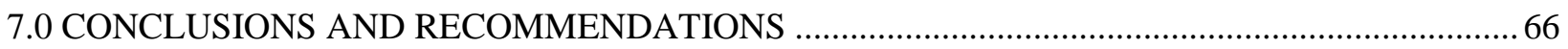

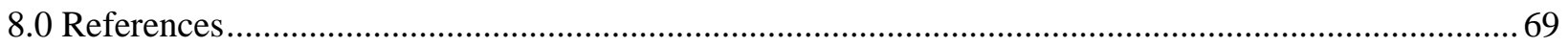

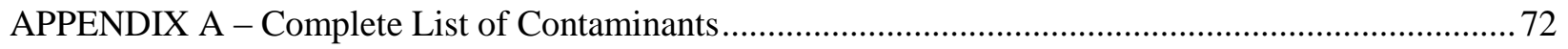

APPENDIX B - Raw Influent and Effluent Event Mean Concentrations for the FCWQF CSW

Component and the Entire Treatment Train ...................................................................................... 74

\section{LIST OF FIGURES}

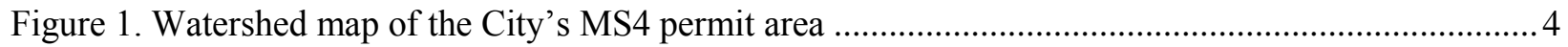

Figure 2. Vicinity map of water quality facilities and their associated pipesheds ...................................... 7

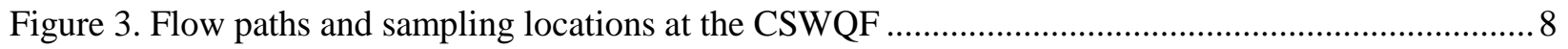

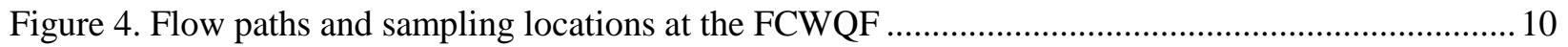

Figure 5. Distribution of TSS and Turbidity (11/2/2011 event ; 3/5/2012 event) .....................................54

Figure 6. Distribution of Total Metals EMCs (11/2/2011 event ; 3/5/2012 event) ..................................56

Figure 7. Distribution of Dissolved Metals EMCs (11/2/2011 event ; 3/5/2012 event) ..........................57

Figure 8. Distribution of Nutrient EMCs (11/2/2011 event ; 3/5/2012 event) ........................................60

Figure 9. Distribution of Bacteria EMCs (11/2/2011 event ; 3/5/2012 event)........................................61

\section{LIST OF TABLES}

Table 1. Summary of water quality constituents, analytical methods, and handling guidelines................ 13

Table 2. Example of FCWQF Composite Sampling Schedule .............................................................. 15

Table 3. Sampling events and number of samples contained in the long-term dataset............................. 18

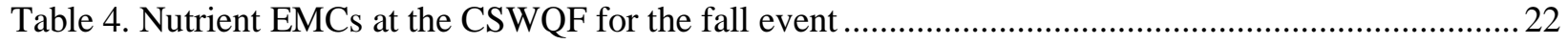

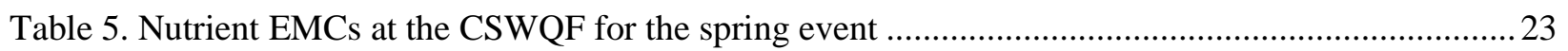

Table 6. General chemistry EMCs at the CSWQF for the fall event .....................................................23

Table 7. General chemistry EMCs at the CSWQF for the spring event .................................................24

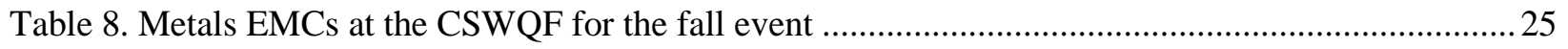


Table 9. Metals EMCs at the CSWQF for the spring event.............................................................26

Table 10. Pesticide, phthalate, PAH, and VOC EMCs at the CSWQF for the fall event ........................28

Table 11. Pesticide, phthalate, PAH, and VOC EMCs at the CSWQF for the spring event......................29

Table 12. Bacteria EMCs at the CSWQF for the fall event ..................................................................... 30

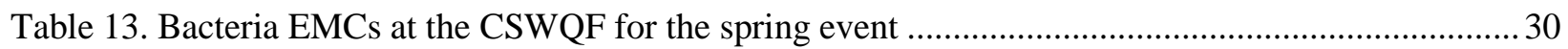

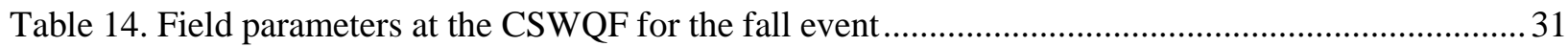

Table 15. Nutrient EMCs at the SFB and WDP components of the FCWQF for the fall event................33

Table 16. Nutrient EMCs at the CSW component and the entire FCWQF treatment train for the fall event

Table 17. Nutrient EMCs at the SFB and WDP components of the FCWQF for the spring event ........... 33

Table 18. Nutrient EMCs at the CSW component and the entire FCWQF treatment train for the spring event

Table 19. General chemistry EMCs at the SFB and WDP components of the FCWQF for the fall event. 35 Table 20. General chemistry EMCs at the CSW component and the entire FCWQF treatment train for the fall event

Table 21. General chemistry EMCs at the SFB and WDP components of the FCWQF for the spring event

Table 22. General chemistry EMCs at the CSW component and the entire FCWQF treatment train for the

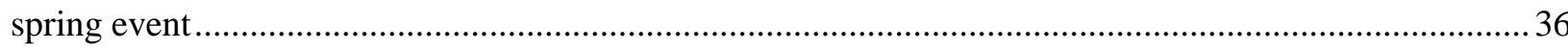

Table 23. Metal EMCs at the SFB and WDP components of the FCWQF for the fall event ...................38 Table 24. Metal EMCs at the CSW component and the entire FCWQF treatment train for the fall event.39 Table 25. Metal EMCs at the SFB and WDP components of the FCWQF for the spring event ...............40 Table 26. Metal EMCs at the CSW component and the entire FCWQF treatment train for the spring event

Table 27. Pesticide, phthalate, PAH, and VOC EMCs at the SFB and WDP components of the FCWQF for the fall event

Table 28. Pesticide, phthalate, PAH, and VOC EMCs at the CSW component and the entire FCWQF treatment train for the fall event

Table 29. Pesticide, phthalate, PAH, and VOC EMCs at the SFB and WDP components of the FCWQF for the spring event .....

Table 30. Pesticide, phthalate, PAH, and VOC EMCs at the CSW component and the entire FCWQF treatment train for the spring event

Table 31. Bacteria concentrations at the SFB and WDP components of the FCWQF for the fall event....48 Table 32. Bacteria concentrations at the CSW component and the entire FCWQF treatment train for the fall event

Table 33. Bacteria concentrations at the SFB and WDP components of the FCWQF for the spring event 49 Table 34. Bacteria concentrations at the CSW component and the entire FCWQF treatment train for the spring event

Table 35. Field parameters at the SFB and WDP components of the FCWQF for the fall event.

Table 36. Field parameters at the CSW component and the entire FCWQF treatment train for the fall

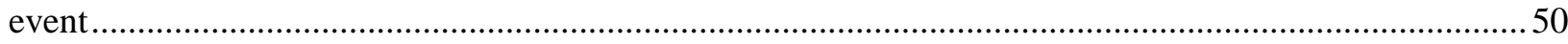

Table 37. Wilcoxon Signed Rank test results for parameters at the FCWQF.......................................51

Table 38. Influent and effluent EMCs for the FCWQF and the BMP Database.......................................53 
Table 39. Raw nutrient EMCs at the CSW component and the entire FCWQF treatment train for the fall event.

Table 40. Nutrient EMCs at the CSW component and the entire FCWQF treatment train for the spring event

Table 41. Raw general chemistry EMCs at the CSW component and the entire FCWQF treatment train for the fall event.

Table 42. Raw general chemistry EMCs at the CSW component and the entire FCWQF treatment train for the spring event

Table 43. Raw metals EMCs at the CSW component and the entire FCWQF treatment train for the fall event.

Table 44. Raw metals EMCs at the CSW component and the entire FCWQF treatment train for the spring event.

Table 45. Raw organics EMCs at the CSW component and the entire FCWQF treatment train for the fall event. .77

Table 46. Raw organics EMCs at the CSW component and the entire FCWQF treatment train for the spring event .78 Table 47. Raw bacteria concentrations at the CSW component and the entire FCWQF treatment train for the fall event.

Table 48. Raw bacteria concentrations at the CSW component and the entire FCWQF treatment train for the spring event 


\subsection{GLOSSARY OF TERMS}

BMP: Best management practice

BMP Database: International Stormwater BMP Database

$\mathrm{BOD}_{5}$ : Five-day biochemical oxygen demand

BYP: Bypass/secondary inlet

CIP: Capital improvement program

City: City of Gresham

CSW: Constructed stormwater wetland

CSWQF: Columbia Slough Water Quality

Facility

CWA: Clean Water Act

DEQ: Department of Environmental Quality

EMC: Event mean concentration

FCWQF: Fairview Creek Water Quality Facility

MRL: Method reporting limit

MS4: Municipal separate storm sewer

$\mathrm{NH}_{3}-\mathrm{N}$ : Ammonia-nitrogen
$\mathrm{NO}_{3}-\mathrm{N}$ : Nitrate-nitrogen

NPDES: National Pollutant Discharge Elimination System

OP: Orthophosphate phosphorus

PAH: Polynuclear aromatic hydrocarbon

SFB: Sedimentation forebay

TH: Total hardness as $\mathrm{CaCO}_{3}$

TKN: Total Kjeldahl Nitrogen

TMDL: Total maximum daily load

TOC: Total organic carbon

TP: Total phosphorus

TSS: Total suspended solids

VOC: Volatile organic compound

WDP: Wet detention pond

WPCL: Water Pollution Control Laboratory

WQT: Water quality terrace

\subsection{INTRODUCTION}

\subsection{Project Background}

As the population of northwestern Oregon becomes steadily more urbanized, stream ecosystems function under increasingly stressful conditions. Converting land from rural to urban uses creates significant tracts of impervious surface (McMahon \& Cuffney, 2000). These surfaces reduce infiltration and generate stormwater that is rapidly delivered directly to streams. For this reason, urban drainage is characterized by higher peak flows and higher runoff volumes than are found in the natural landscape (Barringer et al., 1994; Paul \& Meyer, 2001). In addition to altering hydrology, stormwater runoff impairs 
water quality by transporting pollutants from impervious surfaces directly to streams. These pollutants include excess sediment, nutrients from fertilizer applications, and heavy metals (Paul \& Meyer, 2001). Stormwater pollution limits primary productivity, reduces the available habitat for benthic organisms (Wood \& Armitage, 1997), and reduces the survivability of salmon (Korstrom \& Birtwell, 2006). Streams in urban areas almost always show a reduced abundance of sensitive species and increased numbers of disturbance-tolerant species (Wang \& Lyons, 2003). Even streams that currently meet Total Maximum Daily Load (TMDL) requirements may contain high enough concentrations of heavy metals to severely impact aquatic communities. For instance, research by Waser et al. (2009) shows that trace amounts of copper cause a reduction in critical swimming speed and severely affect the ability of salmon to sense chemical cues and escape predators. Thus, water quality degradation due to stormwater inputs can have serious impacts on fish and aquatic life. Damage to the aquatic food web, as well as increases in the loads of bacteria and lipophilic toxins can lead to the impairment of additional beneficial uses.

Many cities are actively constructing stormwater management facilities in order to reduce stormwater pollution to urban water bodies and meet the requirements of regulatory permits. The City of Gresham is among those required under the federal Clean Water Act (CWA) to minimize pollutant discharges into surface waters. Under the CWA and Oregon Revised Statute 468B.050, the City has been issued a National Pollutant Discharge Elimination System (NPDES) Municipal Separate Storm Sewer System (MS4) Discharge Permit by the Oregon Department of Environmental Quality (DEQ). As a condition of this permit, the City developed a Storm Water Management Plan (SWMP) to minimize pollutant discharges to natural waterbodies via stormwater to the maximum extent practicable. As of 2010, the City owns and operates 18 neighborhood and 3 regional water quality facilities, 22 swales, 6 raingarden complexes, and 133 proprietary devices that help meet this goal (Keri Handaly, personal communication, August 3, 2011). These water quality facilities utilize Best Management Practices (BMPs) such as wet detention ponds, constructed stormwater wetlands, sedimentation basins, and bioswales. 
These BMPs treat stormwater that is generated by development in the five watersheds that fall within the City of Gresham's MS4 permit area. The MS4 permit area includes the incorporated areas of the City except the portions of the City's stormwater system that drain to Underground Injection Control (UIC) systems (Watershed Management Division, 2011). UICs drain to groundwater and require a Water Pollution Control Facility permit, and they are excluded from further consideration by this report. Figure 1 shows the watersheds within the City's permit area and the areas of future annexation. Approximately 11.4 square miles (47 percent) of the City's MS4 permit area lies directly within the Columbia Slough watershed and the Fairview Creek watershed, which is recognized as being the headwaters of the Columbia Slough. The Columbia Slough is on the 303(d) list for chlorophyll $a$, dissolved oxygen, pH, phosphorus, bacteria, DDE/DDT, dieldrin, PCBs, lead, dioxin, and temperature, and DEQ developed TMDLs in 1998 for these impairments. Fairview Creek is on the 303(d) list for temperature and bacteria, and DEQ developed TMDLs for these pollutants in 1998 as a part of the Columbia Slough TMDL. 8.6 square miles (36 percent) of the City's permit MS4 area falls within the Johnson Creek watershed and is tributary to the Lower Willamette River. Johnson Creek is on the 303(d) list for temperature, bacteria, DDT, and dieldrin, and DEQ developed TMDLs in 2006 as a part of the Willamette Basin TMDL. Johnson Creek was added to the 303(d) list for PCBs and PAHs in 2002, but TMDLs have not been developed yet for these pollutants. 4.1 square miles (17 percent) of the City's MS4 permit area falls within the Kelly Creek and Beaver Creek watersheds. The Kelly Creek watershed is tributary to Beaver Creek and ultimately to the Sandy River. Both waterbodies are on the 303(d) list for bacteria, and DEQ developed TMDLs in 2005 as a part of the Sandy River Basin TMDL. 
The previous paragraph demonstrates the complexity of stormwater management, for the City is required to control a variety of pollutants at several different levels of management. Many pollutants such as temperature and bacteria have TMDLs and resultant water quality management plans. Other pollutants such as copper and pentachlorophenol that may one day prove to be impairing water quality within the City's watersheds. The City's water quality facilities are one approach at using BMPs to reduce concentrations of pollutants that impair the beneficial uses of its waterbodies - whether or not they are currently required to manage for them.

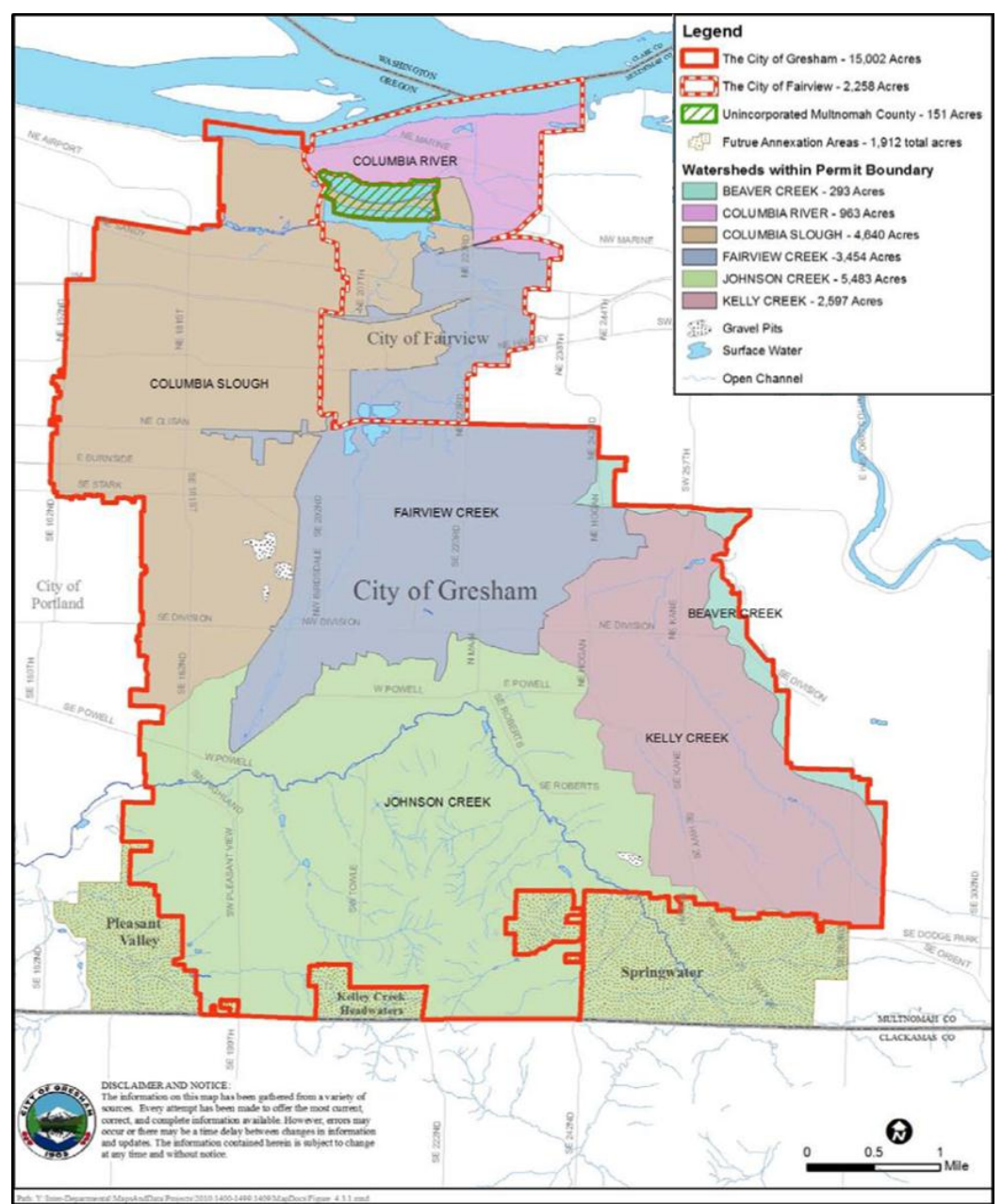

Figure 1. Watershed map of the City's MS4 permit area

The Kelly Creek Pond and Swale is a facility that the City originally designed to provide downstream flood mitigation, and it is targeted to be redesigned under the City's Capital Improvement Program (CIP). Beginning in 2012, the existing Kelly Creek facility will be redesigned to continue providing flood control, while also reducing stormwater pollutant concentrations in Kelly Creek from the upstream watershed. The City is considering the use of a multi-component water quality facility similar to those in use in the Fairview Creek and Columbia Slough watersheds. These facilities use "treatment trains" consisting of multiple components including sedimentation forebays, wet detention ponds, and/or constructed wetland features to treat stormwater using several methods prior to its discharging to natural 
waterbodies. City staff has been studying the effectiveness of the Fairview Creek Water Quality Facility (FCWQF) at reducing pollutant concentrations for the last 4 years. It is known that the facility reduces concentrations of bacteria, total suspended solids, and solid-phase metals, but there is no data available to indicate which facility components are generating the greatest reductions. The Columbia Slough Water Quality Facility (CSWQF) was designed to remove heavy metals, oil and grease, suspended solids, nutrients, and other pollutants of concern, but prior to this study, no data had been collected to assess its effectiveness. This study will provide information to aid in our understanding of which BMPs provide the highest level of treatment.

While national and international data is available on the pollutant removal efficiencies of various stormwater facility components, including those used at the CSWQF and FCWQF, there is little specific data pertaining to the performance of facility components with the soils, hydrology, and pollutant issues unique to this area. Many of the studies within the International BMP database deal with pollutant concentrations that are very different than those found in the City of Gresham's watersheds. For instance, studies examining the effectiveness of wet detention ponds at removing total copper and lead reveal that the median effluent concentrations for these facilities nation-wide are much higher than Gresham's influent concentrations. Differences in influent concentrations may be partly attributable to the City of Gresham's extensive use of non-structural, pretreatment stormwater BMPs. For example, monthly street sweeping and biannual catch basin cleaning reduce stormwater pollutant concentrations before they ever come in contact with a water quality facility. Pollutant removal efficiencies vary greatly by location, and it is critical to understand how a treatment train using the components found at Gresham's facilities helps meet existing TMDLs and reduces concentrations of other pollutants that might cause future 303(d) listings. Once the effectiveness of the BMPs is quantified, City staff will be able to make the best decisions about which BMPs should be used at Kelly Creek and in other watersheds to meet current TMDLs and provide treatment for additional pollutants that may be listed in the future. 


\subsubsection{Goal}

The goal of this research project is to provide those responsible for making stormwater management policy decisions with the information necessary to redesign the existing Kelly Creek detention facility and provide the maximum water quality treatment practicable for the investment made at future facilities.

\subsubsection{Objective}

The objectives of this monitoring project are to produce an assessment of the performance of the water quality facilities and their components and to use this as a demonstration for the effectiveness of similar BMP's at removing pollutant inputs from municipal stormwater discharges. The performance assessment uses effluent event mean concentration (EMC) and removal efficiency ratios to represent the effectiveness of the facilities.

The concentrations of the influent and effluent for each sampling event are compared in this report using EMCs for the entire CSWQF treatment train, the entire FCWQF treatment train, and each of the FCWQF's treatment train components. The EMC method of representing pollutant concentrations is frequently used for the quantification of event-based pollutant removal (Carleton et al., 2001; Wadzuk, et al., 2010); it is considered to be the most useful means for quantifying the level of pollution resulting from a runoff event and therefore the most useful means for quantifying the level of pollution reduction resulting from stormwater treatment (GeoSyntec Consultants \& UWRRC of ASCE, 2002). The use of an EMC instead of an event median concentration also simplifies data collection and analysis tremendously by utilizing a single composite sample rather than a large number of grab samples. Pollutant removal efficiencies are calculated and are based partly on previously collected data and partly on the data obtained from this project's two sampling events.

Due to the inherent variability of water quality in stormwater samples, statistical comparisons are not always applicable. Statistical comparisons between the influent and effluent EMCs for parameters which 
have been monitored in 8 or more sampling events are presented in this report along with initial conclusions and recommendations. Statistical comparisons will not be made for parameters that have been monitored in fewer than 8 storm events. The results of the project's two sampling events for these nonstatistically significant parameters are discussed in a narrative format instead. In the future, better comparisons may be made when additional data makes it possible to achieve a higher level of statistical confidence.

\subsection{Project Setting}

\subsubsection{Location}

Error! Reference source not found. shows a vicinity map for the two water quality facilities and the "pipesheds" that drain to them. The CSWQF is located in the North Gresham Neighborhood district. It is bounded by vacant properties to the west, Sandy Boulevard to the south, a commercial property to the east, and a dike adjacent to the Columbia Slough to the north. The FCWQF is located in the Northwest Neighborhood district on property adjacent to NW Birdsdale Ave. It is bounded by NW Birdsdale Ave to the east, NW Division St to the south, the Fairview Creek trail to the west, and residential properties to the north.

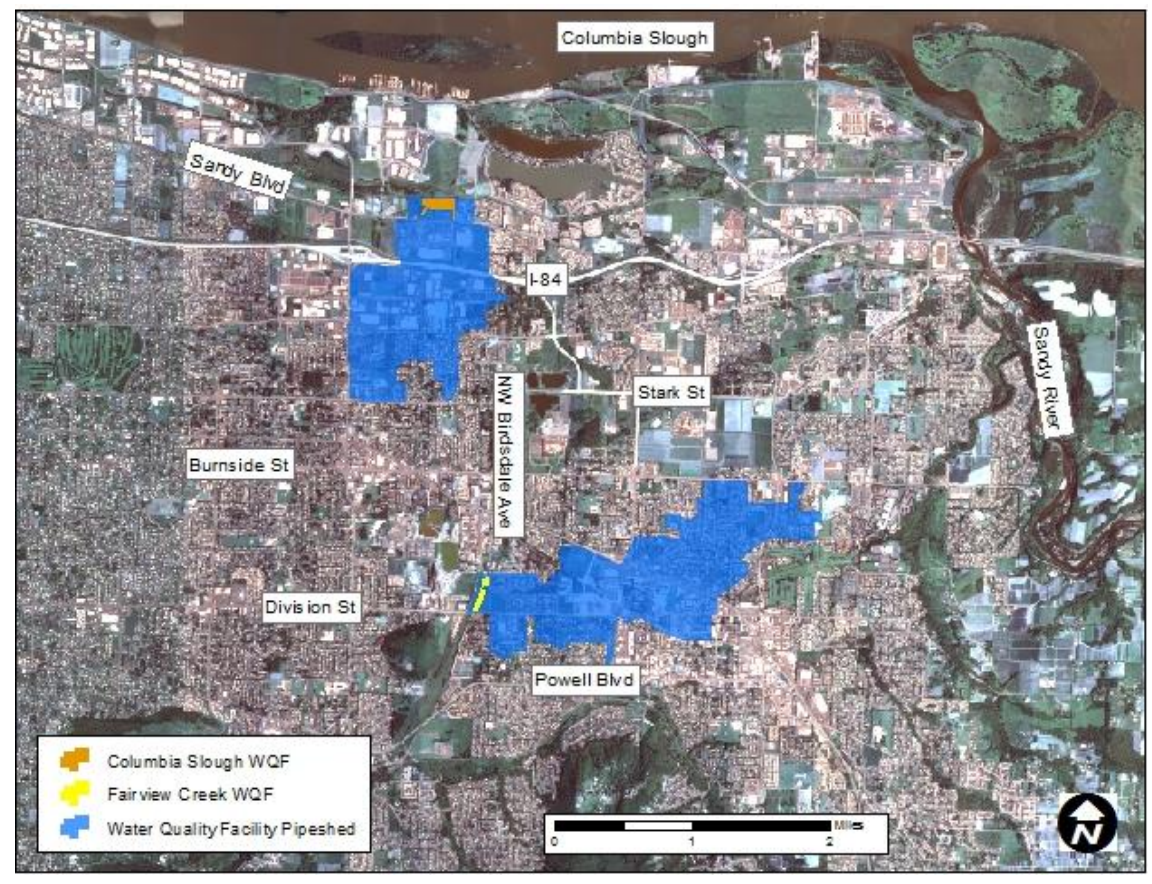

Figure 2. Vicinity map of water quality facilities and their associated pipesheds 


\subsubsection{Water Quality Facility Design}

The CSWQF was constructed between 2007 and 2008 to provide stormwater treatment for approximately 709 acres of commercial and industrial development that previously discharged directly to the Columbia Slough. The location of the facility and the pipeshed that drains to it are shown in Error! Reference source not found. The facility is comprised of three distinct stormwater treatment components that together form the treatment train as shown in Figure 3. The first component is made up of a sedimentation manhole at each of the two inlets. The second component consists of two linear sedimentation forebays (SFB). Municipal stormwater flows from the city's storm sewer through two separate inlets into the sedimentation manholes and SFBs where solid elements and suspended materials are removed by sedimentation. Stormwater then flows into the third component of the treatment train $-\mathrm{a}$ series of five long, narrow water quality terraces (WQT). These terraces fulfill a function similar to that of

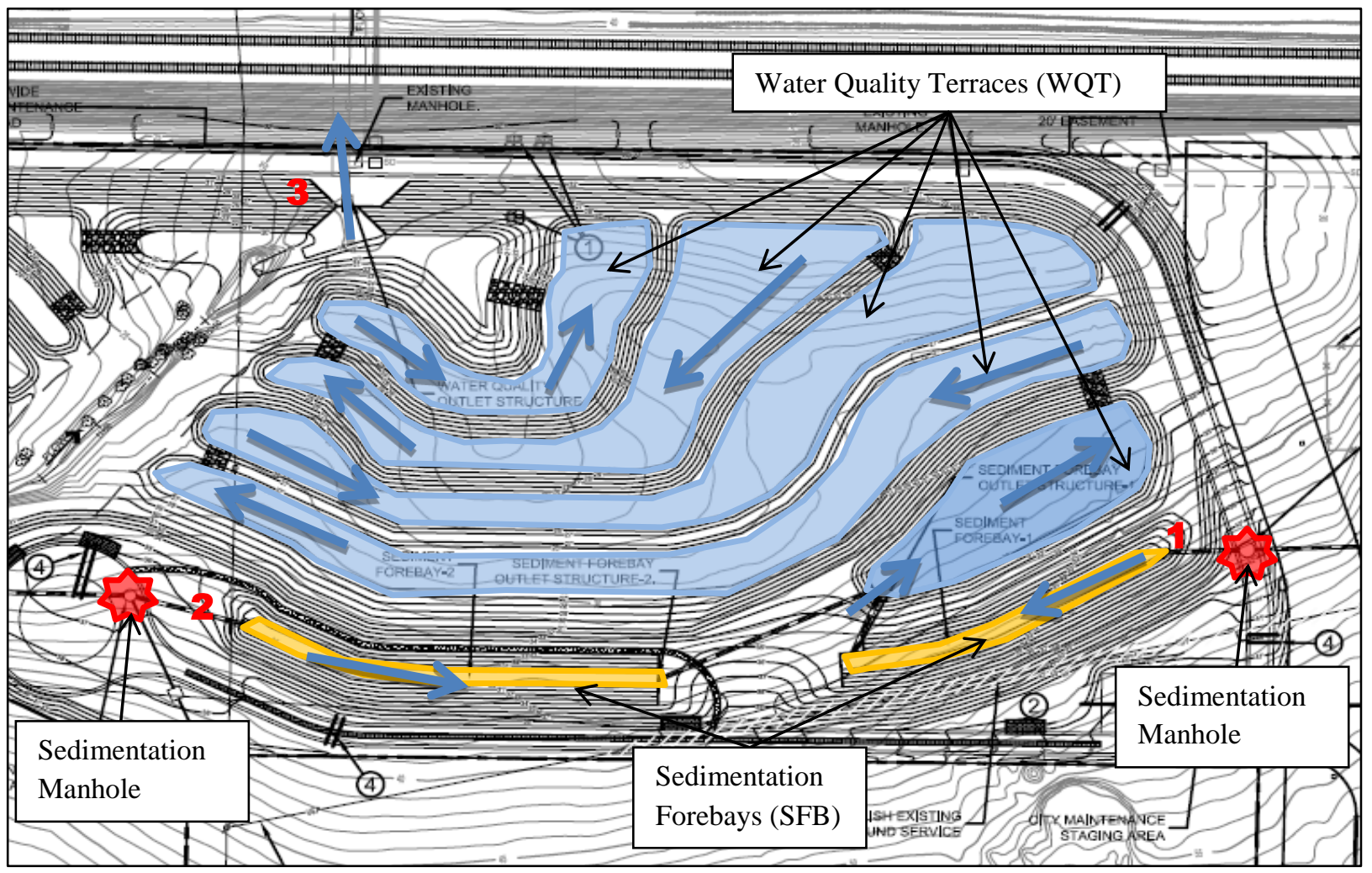

Figure 3. Flow paths and sampling locations at the CSWQF 
bioswales. Flows work their way through the WQTs where additional suspended materials are allowed to settle out and the stormwater is exposed to bioremediation by soil and wetland plant communities. At the end of the final WQT, the treated stormwater is discharged to the Columbia Slough.

The FCWQF was constructed between 2005 and 2006 as a multi-component water quality facility intended to provide flood control and stormwater treatment for low storm flows and urban runoff passing through the site before they reach Fairview Creek and the Columbia Slough. The FCWQF covers an area of 7 acres and provides stormwater management for approximately 959 acres of residential, commercial, and industrial development. Error! Reference source not found. shows the location and pipeshed for the FCWQF.

The facility is comprised of three distinct stormwater treatment components that together form the treatment train as shown in Figure 4. The first component is made up of a small, rectangular sedimentation forebay (SFB). Stormwater flows from the city's storm sewer into the SFB where solid elements and suspended materials are removed by sedimentation. Stormwater then flows into the second component of the treatment train - a long, narrow wet detention pond (WDP). The WDP has an existing pool of water that is retained between storm events to maintain soil and water quality conditions that are beneficial to particulate settling and pollutant attenuation under saturated conditions. Finally, stormwater flows at a controlled rate into the third component of the treatment train - the constructed stormwater wetland (CSW) - allowing for temporary detention up to the design storm. Low flows work their way through the CSW where additional suspended materials are allowed to settle out and the water is exposed to bioremediation by soil and wetland plant communities. At the lower end of the CSW, the treated stormwater is discharged to Fairview Creek. During large storm events that might otherwise overwhelm the capacity of the WDP, excess stormwater is allowed to bypass the first two components of the treatment train through a secondary inlet pipe (BYP), and it enters the constructed wetland directly, quickly combines with treated water, and is discharged. This design reduces the possibility of upstream flooding but does not provide optimal water quality treatment during large storm events. 


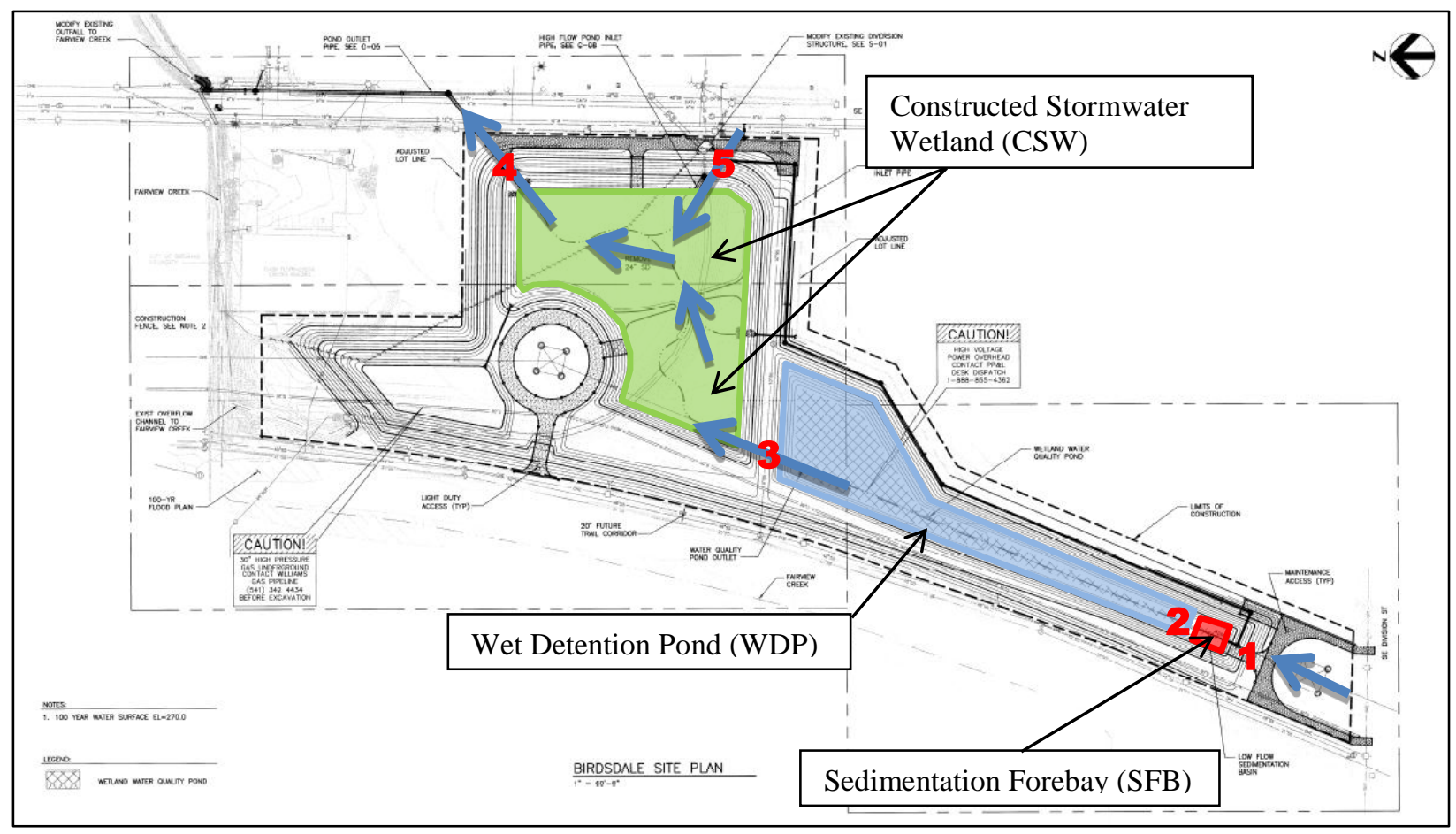

Figure 4. Flow paths and sampling locations at the FCWQF

\subsubsection{BMP Specifications}

The CSWQF and FCWQF were designed to detain flow from a $1.2 \mathrm{in} / \mathrm{hr}$ storm for a 36 hour period releasing $50 \%$ of the stormwater during the first 12 hours and the remaining $50 \%$ during the next 24 hours. In reality, approximately 24 hours pass between peak inflow and peak outflow.

\subsection{METHODS}

\subsection{Storm Selection}

Water quality monitoring was conducted for two individual storm events during the period from October 2011 to March 2012. This study used storm selection criteria adapted from studies by Hood et al. (2007) and Carleton et al. (2000). An attempt was made to use storms meeting the following criteria: 1) a minimum of 0.5 inch of total precipitation, 2) an antecedent dry period of 48 hours, 3) a 24-hour period of negligible rainfall following the event, and 4) 24 hours of no significant runoff entering the facility 
preceding and following the event. 0.5 inch of total precipitation ensured that adequate flows were present to fill the facility and provide significant flow at the outlet. Since the facilities retain stormwater for a 24hour period, having a 48-hour period of relative dryness before and 24 hours after the storm event will ensure that the mixing of stormwater from different storm events is kept to a minimum throughout the length of the treatment trains. The storm criteria were targets and were somewhat flexible out of necessity due to our inability to predict the exact nature of storm events. They were adapted in the field, and the results of this research are discussed in light of any deviations from the storm selection criteria. Sampling was conducted throughout the rise and fall of the hydrograph and stopped when outflow from the facilities returned to approximately base flow levels. The return to base flow conditions was visually estimated in the field, and the time that this occurred was later verified using the facilities' stormwater hydrographs.

\subsection{Flow Estimation}

Inflow and outflow rates for each component of the system were recorded using pressure-based flow meters that are currently installed at sampling location 1,2, and 3 at the CSWQF and sampling locations 3,4 , and within the stormwater conveyance system at the point where the primary and secondary inlet pipes diverge at the FCWQF. The flow meters provided continuous data that was recorded every 15 minutes. Rainfall was also measured onsite using a tipping bucket rain gage and recorded at 15 minute intervals.

\subsection{Water Quality Sampling}

The efficiency with which the components of the treatment trains remove nutrients, metals, E. coli, organic compounds, pesticides, and several other contaminants during wet weather storm events was measured for two storms during 2011-2012. A complete list of the measured pollutants is given in Appendix A. 
Samples were collected at three location within the CSWQF and five locations within the FCWQF (Figure 3 and 4) in order to quantify the pollutant removal efficiency of each treatment train component. Within the CSWQF, samples were collected at 1) the facility's eastern inlet immediately above the SFB, 2) the facility's western inlet immediately above the SFB, and 3) the facility's outlet to the Columbia Slough from the final WQT. Within the FCWQF, samples were collected at 1) the facility's water quality inlet immediately above the SFB, 2) the discharge point between the SFB and the WDP, 3) the discharge point between the WDP and the CSW, 4) the facility's outlet to Fairview Creek from the CSW, and 5) the facility's secondary inlet immediately above the CSW. Sampling at these locations quantified contaminant removal and aided in calculating removal efficiencies for each of the facilities as well as for the individual treatment train components. The best attempt was made to collect samples from flowing water at each discharge point to ensure that the sample's water chemistry was representative of the stormwater entering and exiting that component of the treatment train and was not biased toward water that had already received partial treatment.

The analysis of a long-term dataset is discussed in Section 3.4. For the sampling events that occurred at the FCWQF prior to $11 / 2 / 2011$ and are contained in the long-term dataset, influent samples were collected in the stormwater conveyance system "upstream" of the weir that diverts excess flow to the secondary inlet. This sampling point is upstream of sampling locations 1 and 5. Effluent samples for these events were collected at sampling location 4 .

Composite samples were collected for most of the contaminants as shown in Table 1. A time-paced, constant-volume composite sampling technique was used to generate storm EMC for each contaminant at each sampling location. Equal volume aliquots of 2/3 liter were manually collected at equal increments of time and composited in the field. This sample collection method resulted in an 8-liter composite sample. The aliquot collection frequency for composite samples differed among the treatment train components. Each composited sample was made up of 12 aliquots collected throughout the storm event. This number was intended to provide a manageable, yet sufficient number of aliquots with which to generate a 
representative sample. Increasing the number of aliquots collected would increase the representativeness of the sample but would also increase the complexity and difficulty of manually collecting aliquots from 8 separate locations.

Table 1. Summary of water quality constituents, analytical methods, and handling guidelines

\begin{tabular}{|c|c|c|c|c|}
\hline Water Quality Parameter & Analytical Method & $\begin{array}{l}\text { Sample } \\
\text { Type }\end{array}$ & $\begin{array}{l}\text { Container } \\
\text { Type }^{1}\end{array}$ & $\begin{array}{c}\text { Maximum } \\
\text { Holding } \\
\text { Time }\end{array}$ \\
\hline \multicolumn{5}{|l|}{ BACTERIA } \\
\hline E. Coli & Colilert QT & Grab & $\mathrm{P}$ & $\begin{array}{c}6-24 \\
\text { hours }\end{array}$ \\
\hline CHLORINATED HERBICIDES & EPA 515.3 & Composite & G & 7 days \\
\hline \multicolumn{5}{|l|}{ GENERAL CHEMISTRY PARAMETERS } \\
\hline BOD, 5-day & SM 5210B/H10369 & Composite & G & 48 hours \\
\hline Total Organic Carbon & SM 5310C & Grab & G & 28 days \\
\hline Total Hardness & SM 2340B & Composite & G & 6 months \\
\hline Total Suspended Solids & SM 2540D & Composite & G & -- \\
\hline \multicolumn{5}{|l|}{ MERCURY CONSTITUENTS } \\
\hline $\mathrm{Hg}$, Dissolved & EPA $1631 E$ & Grab & G & 28 days \\
\hline Hg, Total & EPA $1631 E$ & Grab & $\mathrm{FP}$ & 28 days \\
\hline Hg, Methyl, Dissolved & EPA 1630 & Grab & G & 48 hours \\
\hline Hg, Methyl, Total & EPA 1630 & Grab & G & 48 hours \\
\hline METALS by ICPMS & EPA 200.8 & Composite & G & 6 months \\
\hline \multicolumn{5}{|l|}{ NUTRIENTS } \\
\hline Ammonia-Nitrogen & EPA 350.1 & Composite & G & 28 days \\
\hline Nitrate-Nitrogen & EPA 300.0 & Composite & G & 48 hours \\
\hline Total Kjeldahl Nitrogen & PAI-DK03 & Composite & G & 28 days \\
\hline Orthophosphate & EPA 365.1 & Composite & G & 48 hours \\
\hline Total Phosphorus & EPA 365.4 & Composite & G & 28 days \\
\hline ORGANOCHLORINE PESTICIDES by CAS & EPA 3535A & Composite & G & 7 days \\
\hline PHTHALATES by GCMS-SIM & EPA $8270-S I M$ & Composite & G & 7 days \\
\hline $\begin{array}{l}\text { POLYNUCLEAR AROMATIC } \\
\text { HYDROCARBONS by GCMS-SIM }\end{array}$ & EPA 8270-SIM & Composite & G & 7 days \\
\hline \multicolumn{5}{|l|}{ FIELD PARAMETERS } \\
\hline Conductivity & $\begin{array}{c}\text { Calibrated } \\
\text { Conductivity Meter }\end{array}$ & In situ & -- & -- \\
\hline Dissolved Oxygen & Calibrated Oxygen Meter & In situ & -- & -- \\
\hline $\mathrm{pH}$ & Calibrated pH Meter & In situ & -- & -- \\
\hline Temperature & Digital Thermometer & In situ & -- & -- \\
\hline Turbidity & Calibrated Turbidimeter & In situ & -- & -- \\
\hline $\begin{array}{l}\text { VOLATILE ORGANIC COMPOUNDS by } \\
\text { GCMS }\end{array}$ & EPA 8260 & Grab & G & 7 days \\
\hline
\end{tabular}

${ }^{1}$ G: glass; P: polyethylene; FP: fluoropolymer 
For the CSWQF, the aliquot collection frequency at sampling locations 1 and 2 was based directly on the length of the forecasted storm event. This collection frequency is also true for the FCWQF at sampling locations 1,2 , and 5 and was calculated by dividing the forecasted storm length by the 12 aliquots to yield the sampling frequency. This ensured that a sufficient number of samples were collected at the inlets and the SFB outlets - sampling locations where flow is only present during the storm event itself. Due to the retention time of the WDP, CSW, and WQT components, aliquots were collected at a different frequency at sampling location 3 in the CSWQF and locations 3 and 4 in the FCWQF in order to collect an equivalent number of samples as stormwater leaves the facilities over the 24-hour drawdown period. This frequency was calculated by taking the forecasted length of the storm event plus the length of the drawdown period and dividing that number by the 12 aliquots. For example, during an 8-hour storm, aliquots are collected every 40 minutes at FCWQF sampling locations 1, 2, and 5. The length of the storm plus the length of the drawdown period is 32 hours ( 8 hours +24 hours). Therefore, frequency of aliquot collection at FCWQF sampling locations 3 and 4 should be one aliquot every 2 hours 40 minutes.

Grab samples were collected for E. coli, mercury (total and dissolved), methylmercury (total and dissolved), and volatile organic compounds (VOCs). E. coli was sampled three times at each location, during the rising limb, peak, and falling limb of the storm hydrograph. This provided a reasonable estimation of bacteria levels throughout the storm event and allowed samples to be analyzed within the 24 hour maximum holding time. Rather than using an EMC for bacteria, a geometric mean was used to describe concentrations during the event. Mercury and methylmercury constituents were sampled once at each sampling location. The number of samples collected was limited by the high cost of analysis for these constituents. Since VOCs are typically not present in stormwater samples, a single grab sample obtained during the rising limb was used to test for their presence. VOCs were collected during the rising limb because their extreme volatility decreases the likeliness of detection over time.

In situ measurements were made at each sampling location for temperature, $\mathrm{pH}$, conductivity, turbidity, and DO using a field multi-parameter instrument for the first sampling event. These 
measurements were recorded during the rising limb and peak of the storm hydrograph. They were also to be recorded during the falling limb and for the second sampling event, but the timing of other sampling activities often precluded the in situ measurements. These water quality parameters typically do not change dramatically as stormwater moves through the facility (Torrey Lindbo, personal communication, Octeober 12, 2011). Thus, three measurements provide enough data to determine a trend while avoiding the collection of redundant data.

Table 2 provides an example sampling schedule based on the above 8 hour storm event. Obviously, the length of the forecasted event was not necessarily the length of the actual storm event. The collection schedule and number of aliquots collected were therefore target goals and changed in the field during storm events to accommodate changes in the forecasted event.

Table 2. Example of FCWQF Composite Sampling Schedule



\subsection{Water Quality Analysis}

Samples were stored in coolers and transported with gel packs at $4{ }^{\circ} \mathrm{C}$ to the Portland Water Pollution Control Laboratory (WPCL), where they were either analyzed on-site or forwarded to Columbia 
Analytical Services (for analysis of organochlorine pesticides) or TestAmerica (for analysis of chlorinated herbicides, mercury constituents, and total organic carbon). Samples were labeled with the project name, sample identification number, site location, and date and time collected (for grab samples). Chain of custody forms accompanied samples throughout the process, and samples were analyzed within the maximum holding time.

At the CSWQF, it was intended that the facility influent EMC for each constituent would be calculated using a weighted sum as show in Equation 1. The percentage of flow through the West and East inlets to the total facility influent was to be calculated for each sampling event and multiplied by the EMC at that sampling point. The two weighted concentrations were to be summed to estimate a facility influent EMC.

\section{Equation 1}

Total Influent EMC $=\left(\frac{V_{w}}{V_{t}} * E M C_{w}\right)+\left(\frac{V_{e}}{V_{t}} * E M C_{e}\right)$

$$
\begin{aligned}
& \text { where } \quad V_{w}=\text { volume of stormwater entering through the West inlet } \\
& \mathrm{V}_{\mathrm{e}}=\text { volume of stormwater entering through the East inlet } \\
& \mathrm{V}_{\mathrm{t}}=\text { total volume of stormwater } \\
& \mathrm{EMC}_{\mathrm{w}}=\text { event mean concentration of the parameter taken at the West inlet } \\
& \mathrm{EMC}_{\mathrm{e}}=\text { event mean concentration of the parameter taken at the East inlet }
\end{aligned}
$$

However, during the course of the project it was discovered that the flow meters installed in the CSWQF components do not measure flow accurately enough for use in calculating the total influent EMC. As a result, impervious area will be used as a surrogate for stormwater volume to estimate the total influent EMC as shown in Equation 2.

\section{Equation 2}

$$
\begin{aligned}
& \text { Total Influent } E M C=\left(\frac{A_{w}}{A_{t}} * E M C_{w}\right)+\left(\frac{A_{e}}{A_{t}} * E M C_{e}\right) \\
& \text { where } \quad A_{\mathrm{w}}=\text { amount of impervious area draining to the West inlet } \\
& \mathrm{A}_{\mathrm{e}}=\text { amount of impervious area draining to the East inlet } \\
& \mathrm{A}_{\mathrm{t}}=\text { total amount of impervious area } \\
& \mathrm{EMC}_{\mathrm{w}}=\text { event mean concentration of the parameter taken at the West inlet } \\
& \mathrm{EMC}_{\mathrm{e}}=\text { event mean concentration of the parameter taken at the East inlet }
\end{aligned}
$$


This problem also occurred at the FCWQF, but the solution is not as simple. It was originally intended that the total influent for the entire facility and for the CSW component would be calculated using the weighted sum method described above. This is necessary because when the facility's secondary inlet flows, the combined influent EMC from the facility's primary and secondary inlets must be calculated. However, calibration problems with the facility's flow meters made it impossible to determine the volume of stormwater entering the facility through either inlet. As a result, the total influent EMC for the entire facility and for the CSW component are given as a range of values encompassing the EMCs of both inlets. A visual estimate of flow in the primary and secondary inlets was used to develop the weighted sum used in the calculation of total influent EMC. This method of estimation affects the accuracy of the total influent EMCs, but it fortunately does not impact the effluent EMCs. Although less accuracy in the total influent EMCs may affect the removal efficiency ratios described below, effluent EMCs are the primary method of measuring the effectiveness of the two facilities.

Removal efficiency ratios were calculated using the efficiency ratio method as described in the EPA's Urban Stormwater BMP Performance Monitoring guidelines (US EPA, 2002):

\section{Equation 3}

$$
\text { Efficiency Ratio }=\left(\frac{\text { total influent EMC }- \text { ef fluent EMC }}{\text { total influent EMC }}\right) * 100
$$

A long-term dataset containing EMC data for 21 parameters was analyzed to determine if the FCWQF treatment train significantly reduced pollutant concentrations. This dataset contained EMC data for the FCWQF facility influent and effluent during the storm events shown in Table 3. 
Table 3. Sampling events and number of samples contained in the long-term dataset

\begin{tabular}{|c|c|c|c|}
\hline Analyte & Sampling Events & $\begin{array}{l}\text { No. of } \\
\text { Influent } \\
\text { Samples }\end{array}$ & $\begin{array}{l}\text { No. of } \\
\text { Effluent } \\
\text { Samples }\end{array}$ \\
\hline \multicolumn{4}{|l|}{ Nutrients } \\
\hline Ammonia- $\mathrm{N}\left(\mathrm{NH}_{3}-\mathrm{N}\right)$ & $10 / 3 / 08,3 / 23 / 09,10 / 23 / 09,2 / 25 / 10,10 / 24 / 10,5 / 11 / 11,11 / 2 / 11,3 / 5 / 12$ & 8 & 8 \\
\hline Nitrate- $\mathrm{N}\left(\mathrm{NO}_{3}-\mathrm{N}\right)$ & $10 / 3 / 08,3 / 23 / 09,10 / 23 / 09,2 / 25 / 10,10 / 24 / 10,5 / 11 / 11,11 / 2 / 11,3 / 5 / 12$ & 8 & 8 \\
\hline Total Kjeldahl N (TKN) & $10 / 3 / 08,3 / 23 / 09,10 / 23 / 09,2 / 25 / 10,10 / 24 / 10,5 / 11 / 11,11 / 2 / 11,3 / 5 / 12$ & 8 & 8 \\
\hline Orthophosphate (OP) & $10 / 3 / 08,3 / 23 / 09,10 / 23 / 09,2 / 25 / 10,10 / 24 / 10,5 / 11 / 11,11 / 2 / 11,3 / 5 / 12$ & 8 & 8 \\
\hline Total Phosphorus (TP) & $10 / 3 / 08,3 / 23 / 09,10 / 23 / 09,2 / 25 / 10,10 / 24 / 10,5 / 11 / 11,11 / 2 / 11,3 / 5 / 12$ & 8 & 8 \\
\hline \multicolumn{4}{|l|}{ General Chemistry } \\
\hline $\mathrm{BOD}_{5}$ & $10 / 3 / 08,3 / 23 / 09,10 / 23 / 09,2 / 25 / 10,10 / 24 / 10,5 / 11 / 11,11 / 2 / 11,3 / 5 / 12$ & 8 & 8 \\
\hline $\begin{array}{l}\text { Total Suspended } \\
\text { Solids (TSS) }\end{array}$ & $10 / 3 / 08,3 / 23 / 09,10 / 23 / 09,2 / 25 / 10,10 / 24 / 10,5 / 11 / 11,11 / 2 / 11,3 / 5 / 12$ & 8 & 8 \\
\hline \multicolumn{4}{|l|}{ Metals, Dissolved } \\
\hline Copper (DCu) & $10 / 3 / 08,3 / 23 / 09,10 / 23 / 09,2 / 25 / 10,10 / 24 / 10,5 / 11 / 11,11 / 2 / 11,3 / 5 / 12$ & 8 & 8 \\
\hline Lead (DPb) & $10 / 3 / 08,3 / 23 / 09,10 / 23 / 09,2 / 25 / 10,10 / 24 / 10,5 / 11 / 11,11 / 2 / 11,3 / 5 / 12$ & 8 & 8 \\
\hline Nickel (DNi) & $10 / 3 / 08,3 / 23 / 09,10 / 23 / 09,2 / 25 / 10,10 / 24 / 10,5 / 11 / 11,11 / 2 / 11,3 / 5 / 12$ & 8 & 8 \\
\hline Zinc (DZn) & $10 / 3 / 08,3 / 23 / 09,10 / 23 / 09,2 / 25 / 10,10 / 24 / 10,5 / 11 / 11,11 / 2 / 11,3 / 5 / 12$ & 8 & 8 \\
\hline \multicolumn{4}{|l|}{ Metals, Total } \\
\hline Copper (TCu) & $10 / 3 / 08,3 / 23 / 09,10 / 23 / 09,2 / 25 / 10,10 / 24 / 10,5 / 11 / 11,11 / 2 / 11,3 / 5 / 12$ & 8 & 8 \\
\hline Lead (TPb) & $10 / 3 / 08,3 / 23 / 09,10 / 23 / 09,2 / 25 / 10,10 / 24 / 10,5 / 11 / 11,11 / 2 / 11,3 / 5 / 12$ & 8 & 8 \\
\hline Nickel (TNi) & $10 / 3 / 08,3 / 23 / 09,10 / 23 / 09,2 / 25 / 10,10 / 24 / 10,5 / 11 / 11,11 / 2 / 11,3 / 5 / 12$ & 8 & 8 \\
\hline Zinc (TZn) & $10 / 3 / 08,3 / 23 / 09,10 / 23 / 09,2 / 25 / 10,10 / 24 / 10,5 / 11 / 11,11 / 2 / 11,3 / 5 / 12$ & 8 & 8 \\
\hline \multicolumn{4}{|l|}{ Bacteria } \\
\hline E. coli & $\begin{array}{c}3 / 7 / 07,5 / 2 / 07,1 / 14 / 08,2 / 29 / 08,10 / 3 / 08,3 / 23 / 09,10 / 23 / 09,2 / 25 / 10 \\
10 / 23 / 10,5 / 11 / 11,11 / 2 / 11,3 / 5 / 12\end{array}$ & 21 & 23 \\
\hline \multicolumn{4}{|l|}{ Field Parameters } \\
\hline Conductivity & $\begin{array}{c}3 / 7 / 07,5 / 2 / 07,1 / 14 / 08,2 / 29 / 08,10 / 3 / 08,3 / 23 / 09,2 / 25 / 10,10 / 23 / 10 \\
5 / 11 / 11,11 / 2 / 11\end{array}$ & 38 & 39 \\
\hline Dissolved oxygen (DO) & $\begin{array}{c}3 / 7 / 07,5 / 2 / 07,1 / 14 / 08,2 / 29 / 08,10 / 3 / 08,3 / 23 / 09,2 / 25 / 10,10 / 23 / 10 \\
5 / 11 / 11,11 / 2 / 11\end{array}$ & 38 & 40 \\
\hline $\mathrm{pH}$ & $3 / 7 / 07,5 / 2 / 07,2 / 29 / 08,10 / 3 / 08,3 / 23 / 09,2 / 25 / 10,10 / 23 / 10,5 / 11 / 11,11 / 2 / 11$ & 35 & 39 \\
\hline Temperature & $\begin{array}{c}3 / 7 / 07,5 / 2 / 07,1 / 14 / 08,2 / 29 / 08,10 / 3 / 08,3 / 23 / 09,2 / 25 / 10,10 / 23 / 10 \\
5 / 11 / 11,11 / 2 / 11\end{array}$ & 38 & 40 \\
\hline Turbidity & $\begin{array}{c}5 / 2 / 07,1 / 14 / 08,2 / 29 / 08,10 / 3 / 08,3 / 23 / 09,2 / 25 / 10,10 / 23 / 10,5 / 11 / 11 \\
11 / 2 / 11\end{array}$ & 34 & 34 \\
\hline
\end{tabular}

The size of the dataset is sufficient to meet the assumptions of the Wilcoxon Signed Rank test which will be used to compare the influent and effluent EMCs. The Wilcoxon Signed Rank test is a nonparametric statistical hypothesis test used when comparing two related samples to assess whether one of 
the two samples tends to have larger values than the other. It is often used as an alternative to the paired Student's t-test when analyzing environmental data because this data is often not normally distributed. The hypothesis for the one-tailed test is as follows:

$$
\begin{aligned}
& \mathrm{H}_{\mathrm{o}} \text { : median influent EMC }<=\text { median effluent EMC } \\
& \mathrm{H}_{\mathrm{a}}: \text { median influent EMC }>\text { median effluent EMC }
\end{aligned}
$$

The critical value for the test was based upon an alpha of 0.05 . As shown in Table 3, a sample size of 8 was available for the nutrients, general chemistry, dissolved metals, and total metals parameters. The bacteria influent and effluent parameters had samples sizes of 21 and 23, respectively. Sample sizes for the field parameters ranged from 34 to 40 . Multiple grab samples were collected throughout each sampling event for the bacteria and field parameters, resulting in sample sizes that exceed the number of events.

The dataset contained multiple non-detect observations for several parameters. The values of nondetect observations were estimated using the ProUCL Version 4.1.01 software developed by the U.S. Environmental Protection Agency Office of Research and Development (2011) for analysis of environmental data containing non-detect observations. Regression on Order Statistics was used to fit a regression line to the data and then fill in values extrapolated from that line for the observations falling below the detection limit. On occasion, these extrapolated values were either negative or above the detection limit. For these cases, EPA recommendations were followed - a value of half the detection limit was substituted for negative values and the value of the detection limit was substituted for extrapolated values above the detection limit (Singh et al., 2010). The corrected dataset was then analyzed using the Wilcoxon Signed Rank test using the R statistical package. 


\subsection{EVENTS}

\subsection{Fall Event of November 2-3, 2011}

The sampling team sampled a storm event on November 2-3, 2011. The storm event began at 19:45 on $11 / 2 / 2011$ and ended at $1: 15$ on 11/3/2011. Approximately 0.6 inch of precipitation occurred during this period with 0.01 inch occurring in the previous 72 hours, 0.05 inch in the following 24 hours and, 0.13 inch in the following 48 hours. Sampling was conducted at the CSWQF East and West inlets over approximately 4 hours and at the facility outlet over approximately 24 hours. Sampling was conducted at FCWQF sampling locations 1, 2, and 5 over approximately 4.75 hours and at sampling locations 3 and 4 over approximately 24 hours. Sampling was terminated at the point when outflow from the facility returned to approximately base flow conditions as described in Section 3.1.

\subsection{Spring Event of March 5-6, 2012}

The sampling team successfully sampled a storm event on March 5-6, 2012. The storm event began at 10:00 and ended at 14:00 on 3/5/2012. Approximately 0.36 inch of precipitation occurred during this period with 0.09 inch occurring in the previous 72 hours and none in the following 72 hours. Sampling was conducted at the CSWQF East and West inlets and FCWQF sampling locations 1, 2, and 5 over approximately 3.5 hours and at the CSWQF outlet and FCWQF sampling locations 3 and 4 over approximately 24 hours. Sampling was terminated at the point when outflow from the facility returned to approximately base flow conditions as described in Section 3.1. 


\subsection{RESULTS}

\subsection{Estimated Flows}

Flow data was not reliable for either sampling event at the CSWQF or FCWQF. The flow meters at the CSWQF have a history of calibration issues, and these issues resurfaced during the fall and spring sampling events. For instance, during one storm event at the CSWQF the meter at the outlet of a sedimentation forebay registered 5 times the volume of stormwater as was recorded entering the cell even though there are no additional inputs to the cell. In addition, during the fall and spring sampling events, the weir in the flow diversion structure that directs excess flow to the secondary inlet of the FCWQF malfunctioned. As a result, flow was not used to aid in the calculation of total EMC for the facilities. For the CSWQF, modeling suggests that 80 percent of flow enters through the West Inlet and $20 \%$ enters through the East Inlet (Tom McCausland, personal communication, May 2, 2012). This ratio was used to calculate the total influent EMCs for the CSWQF for both sampling events. For the FCWQF, it was visually estimated that the ratio of flow through the primary inlet to the flow through the secondary inlet was 80:20 for the fall event and 90:10 for the spring event. These ratios were used to calculate the total CSW influent EMCs and the total facility influent EMCs for the FCWQF.

\subsection{CSWQF Water Quality Results}

The results of the fall and spring sampling events are meant to be illustrative in nature and do not attempt to quantify the effectiveness of the facility or its individual components in a statistically significant manner. To do this, the results of additional sampling events are necessary. For comparison purposes, removal efficiencies are often represented as percent removal. These removal efficiencies are considered "measurable" if they exceeded the analytical error associated with the laboratory testing. The following thresholds were used to demarcate measurable difference: 1) 10 percent for nutrients, general chemistry, and metals, 2) 20 percent for chlorinated herbicides, PAHs, and VOCs, and 3) 40 percent for 
organochlorine pesticides. Removal efficiencies that do not meet these criteria are not mentioned in the Results section. This method of representing removal efficiency has been justly criticized as being primarily a function of influent quality rather than BMP performance, and variations in percent removal may have little relationship to the quality of effluent that is achieved. For this reason, percent removal is provided merely as a supplement to the effluent concentrations shown in the following tables.

\subsubsection{Nutrients}

The following section along with Tables 4 and 5 provide information by which to assess the effectiveness of the CSWQF treatment train at removing nutrients from stormwater for the fall and spring sampling events. The treatment train did not measurably reduce the EMCs of any nutrients except $\mathrm{NH}_{3}-\mathrm{N}$ during the fall event and experienced an overall increase in nutrient concentration of 47 percent. Although the EMC of $\mathrm{NH}_{3}-\mathrm{N}$ decreased by 47 percent $(0.024 \mathrm{mg} / \mathrm{L})$, the EMCs of $\mathrm{NO}_{3}-\mathrm{N}, \mathrm{TKN}, \mathrm{OP}$, and TP increased between 17 and 104 percent. The treatment train was much more effective at removing nutrients for the spring event and measurably decreased nutrient concentrations by 11 percent. Reductions in the EMCs of $\mathrm{NH}_{3}-\mathrm{N}$, TKN, and TP ranged from 28 to 38 percent. The EMC of $\mathrm{NO}_{3}-\mathrm{N}$ increased once again but this time by only 13 percent.

Table 4. Nutrient EMCs at the CSWQF for the fall event

\begin{tabular}{|c|c|c|c|c|c|c|c|}
\hline \multirow{3}{*}{ Analyte } & \multirow{3}{*}{ Unit } & \multicolumn{6}{|c|}{ 11/2/2011 Storm Event } \\
\hline & & \multicolumn{6}{|c|}{ Entire Facility } \\
\hline & & $\begin{array}{l}\text { West Inlet } \\
\text { Influent } \\
\text { EMC }\end{array}$ & $\begin{array}{c}\text { East Inlet } \\
\text { Influent } \\
\text { EMC }\end{array}$ & $\begin{array}{c}\text { Total } \\
\text { Influent } \\
\text { EMC }\end{array}$ & $\begin{array}{c}\text { Effluent } \\
\text { EMC }\end{array}$ & Difference & $\begin{array}{c}\% \\
\text { Difference }\end{array}$ \\
\hline \multicolumn{8}{|l|}{ Nutrients } \\
\hline Total Nutrients & $\mathrm{mg} / \mathrm{L}$ & 0.80 & 0.62 & 0.76 & 1.1 & -0.36 & $-47 \%$ \\
\hline Ammonia- $\mathrm{N}\left(\mathrm{NH}_{3}-\mathrm{N}\right)$ & $\mathrm{mg} / \mathrm{L}$ & 0.054 & 0.038 & 0.051 & 0.027 & 0.024 & $47 \%$ \\
\hline Nitrate- $\mathrm{N}\left(\mathrm{NO}_{3}-\mathrm{N}\right)$ & $\mathrm{mg} / \mathrm{L}$ & 0.28 & 0.24 & 0.27 & 0.55 & -0.28 & $-104 \%$ \\
\hline Total Kjeldahl N (TKN) & $\mathrm{mg} / \mathrm{L}$ & 0.35 & 0.26 & 0.33 & 0.39 & -0.058 & $-17 \%$ \\
\hline Orthophosphate (OP) & $\mathrm{mg} / \mathrm{L}$ & 0.039 & 0.021 & 0.035 & 0.053 & -0.018 & $-50 \%$ \\
\hline Total Phosphorus (TP) & $\mathrm{mg} / \mathrm{L}$ & 0.0790 & 0.0570 & 0.0756 & 0.0990 & -0.0244 & $-33 \%$ \\
\hline
\end{tabular}

NOTE: BOLD values are measurably different as discussed in Section 5.2. 
Table 5. Nutrient EMCs at the CSWQF for the spring event

\begin{tabular}{|c|c|c|c|c|c|c|c|}
\hline \multirow[b]{3}{*}{ Analyte } & \multirow{3}{*}{ Unit } & \multicolumn{6}{|c|}{ 3/5/2012 Storm Event } \\
\hline & & \multicolumn{6}{|c|}{ Entire Facility } \\
\hline & & $\begin{array}{c}\text { West Inlet } \\
\text { Influent } \\
\text { EMC }\end{array}$ & $\begin{array}{c}\text { East Inlet } \\
\text { Influent } \\
\text { EMC }\end{array}$ & $\begin{array}{c}\text { Total } \\
\text { Influent } \\
\text { EMC }\end{array}$ & $\begin{array}{c}\text { Effluent } \\
\text { EMC }\end{array}$ & Difference & \% Difference \\
\hline \multicolumn{8}{|l|}{ Nutrients } \\
\hline Total Nutrients & $\mathrm{mg} / \mathrm{L}$ & 1.5 & 1.2 & 1.4 & 1.3 & 0.16 & $11 \%$ \\
\hline Ammonia- $\mathrm{N}\left(\mathrm{NH}_{3}-\mathrm{N}\right)$ & $\mathrm{mg} / \mathrm{L}$ & 0.051 & 0.039 & 0.049 & 0.035 & 0.014 & $28 \%$ \\
\hline Nitrate- $\mathrm{N}\left(\mathrm{NO}_{3}-\mathrm{N}\right)$ & $\mathrm{mg} / \mathrm{L}$ & 0.75 & 0.45 & 0.69 & 0.78 & -0.090 & $-13 \%$ \\
\hline Total Kjeldahl N (TKN) & $\mathrm{mg} / \mathrm{L}$ & 0.56 & 0.61 & 0.57 & 0.38 & 0.19 & $33 \%$ \\
\hline Orthophosphate (OP) & $\mathrm{mg} / \mathrm{L}$ & $<0.010$ & $<0.010$ & $<0.010$ & $<0.010$ & Indeterminate & Indeterminate \\
\hline Total Phosphorus (TP) & $\mathrm{mg} / \mathrm{L}$ & 0.120 & 0.140 & 0.124 & 0.0770 & 0.0470 & $38 \%$ \\
\hline
\end{tabular}

NOTE: Indeterminate values may have occurred either because the influent and effluent EMCs were both below the MRL or because an elevated MRL resulted in the MRL for one sample being higher than the detectable value of the other. BOLD values are measurably different as discussed in Section 5.2.

\subsubsection{General Chemistry}

Tables 6 and 7 provide information by which to assess the effectiveness of the CSWQF treatment train at removing $\mathrm{BOD}_{5}$, TOC, and TSS from stormwater for the fall and spring sampling events. Similar to the nutrient results, the treatment train did not measurably reduce the EMCs of any of the above parameters during the fall event. The $\mathrm{EMC}$ of $\mathrm{BOD}_{5}$ did not measurable change, TOC increased by 90 percent, and TSS increased by 107 percent. The performance of the treatment train improved during the spring event, where the EMC of $\mathrm{BOD}_{5}$ decreased by 64 percent and TSS decreased by 70 percent. The EMC of TOC increased again but to a smaller degree - by 11 percent.

Table 6. General chemistry EMCs at the CSWQF for the fall event

\begin{tabular}{|c|c|c|c|c|c|c|c|}
\hline \multirow{3}{*}{ Analyte } & \multirow{3}{*}{ Unit } & \multicolumn{6}{|c|}{ 11/2/2011 Storm Event } \\
\hline & & \multicolumn{6}{|c|}{ Entire Facility } \\
\hline & & $\begin{array}{l}\text { West Inlet } \\
\text { Influent } \\
\text { EMC }\end{array}$ & $\begin{array}{c}\text { East Inlet } \\
\text { Influent } \\
\text { EMC }\end{array}$ & $\begin{array}{l}\text { Total } \\
\text { Influent } \\
\text { EMC }\end{array}$ & $\begin{array}{l}\text { Effluent } \\
\text { EMC }\end{array}$ & Difference & \% Difference \\
\hline \multicolumn{8}{|l|}{ General Chemistry } \\
\hline $\mathrm{BOD}_{5}$ & $\mathrm{mg} / \mathrm{L}$ & 3 & 2 & 3 & 3 & -0.2 & $-7 \%$ \\
\hline $\begin{array}{l}\text { Total Organic Carbon } \\
\text { (TOC) }\end{array}$ & $\mathrm{mg} / \mathrm{L}$ & 1.55 & $<0.500$ & 1.34 & 2.55 & -1.21 & $-90 \%$ \\
\hline $\begin{array}{l}\text { Total Suspended Solids } \\
\text { (TSS) }\end{array}$ & $\mathrm{mg} / \mathrm{L}$ & 6 & 5 & 6 & 12 & -6 & $-107 \%$ \\
\hline
\end{tabular}

NOTE: BOLD values are measurably different as discussed in Section 5.2. 
Table 7. General chemistry EMCs at the CSWQF for the spring event

\begin{tabular}{|c|c|c|c|c|c|c|c|}
\hline \multirow{3}{*}{ Analyte } & \multirow{3}{*}{ Unit } & \multicolumn{6}{|c|}{ 3/5/2012 Storm Event } \\
\hline & & \multicolumn{6}{|c|}{ Entire Facility } \\
\hline & & $\begin{array}{c}\text { West Inlet } \\
\text { Influent } \\
\text { EMC }\end{array}$ & $\begin{array}{c}\text { East Inlet } \\
\text { Influent } \\
\text { EMC }\end{array}$ & $\begin{array}{l}\text { Total } \\
\text { Influent } \\
\text { EMC }\end{array}$ & $\begin{array}{l}\text { Effluent } \\
\text { EMC }\end{array}$ & Difference & \% Difference \\
\hline \multicolumn{8}{|l|}{ General Chemistry } \\
\hline $\mathrm{BOD}_{5}$ & $\mathrm{mg} / \mathrm{L}$ & 3 & 2 & 3 & $<1$ & 2 & $64 \%$ \\
\hline $\begin{array}{l}\text { Total Organic Carbon } \\
\text { (TOC) }\end{array}$ & $\mathrm{mg} / \mathrm{L}$ & 3.07 & 2.12 & 2.88 & 3.21 & -0.330 & $-11 \%$ \\
\hline $\begin{array}{l}\text { Total Suspended Solids } \\
\text { (TSS) }\end{array}$ & $\mathrm{mg} / \mathrm{L}$ & 20 & 20 & 20 & 6 & 14 & $70 \%$ \\
\hline
\end{tabular}

NOTE: BOLD values are measurably different as discussed in Section 5.2.

\subsubsection{Metals}

Tables 8 and 9 provide information by which to assess the effectiveness of the CSWQF treatment train at removing metals from stormwater for the fall and spring sampling events. For the fall event, the treatment train measurably reduced the EMCs of TCd, DPb, DZn, and TZn by 20, 46, 35, and 27 percent, respectively. The EMCs of TAs, DCu, and TNi increased between 12 and 19 percent. For the spring event, the treatment train measurably reduced the EMCs of TSb, DAs, TAs, TCd, TCu, DPb, TPb, TNi, DZn, and TZn. Removal efficiencies ranged from 12 to 44 percent for total metals and 16 to 30 percent for the dissolved metals. DZn and TZn decreased by the greatest absolute amount because they were present at far greater concentrations in stormwater than were most other metals. DSb, DAs, and DCd were not analyzed for in the fall event, but were later added to sampling plan in order to improve our estimates of additional metals. 
Table 8. Metals EMCs at the CSWQF for the fall event

\begin{tabular}{|c|c|c|c|c|c|c|c|}
\hline \multirow[b]{3}{*}{ Analyte } & \multirow[b]{3}{*}{ Unit } & \multicolumn{6}{|c|}{ 11/2/2011 Storm Event } \\
\hline & & \multicolumn{6}{|c|}{ Entire Facility } \\
\hline & & $\begin{array}{l}\text { West } \\
\text { Inlet } \\
\text { Influent } \\
\text { EMC }\end{array}$ & $\begin{array}{l}\text { East Inlet } \\
\text { Influent } \\
\text { EMC }\end{array}$ & $\begin{array}{l}\text { Total } \\
\text { Influent } \\
\text { EMC }\end{array}$ & $\begin{array}{l}\text { Effluent } \\
\text { EMC }\end{array}$ & $\begin{array}{l}\text { Difference } \\
\text { Between } \\
\text { Influent \& } \\
\text { Effluent EMC }\end{array}$ & \% Difference \\
\hline \multicolumn{8}{|l|}{ Metals, Dissolved (composite) } \\
\hline Antimony (DSb) & $\mu \mathrm{g} / \mathrm{L}$ & -- & -- & -- & -- & -- & -- \\
\hline Arsenic (DAs) & $\mu \mathrm{g} / \mathrm{L}$ & -- & -- & -- & -- & -- & -- \\
\hline Cadmium (DCd) & $\mu \mathrm{g} / \mathrm{L}$ & -- & -- & -- & -- & -- & -- \\
\hline Copper (DCu) & $\mu \mathrm{g} / \mathrm{L}$ & 1.82 & 1.70 & 1.80 & 2.01 & -0.214 & $-12 \%$ \\
\hline Lead (DPb) & $\mu \mathrm{g} / \mathrm{L}$ & 0.237 & $<0.100$ & 0.210 & 0.114 & 0.0956 & $46 \%$ \\
\hline Nickel (DNi) & $\mu \mathrm{g} / \mathrm{L}$ & $<0.500$ & $<0.500$ & $<0.500$ & $<0.500$ & Indeterminate & Indeterminate \\
\hline Zinc (DZn) & $\mu \mathrm{g} / \mathrm{L}$ & 26.9 & 26.0 & 26.7 & 17.3 & 9.42 & $35 \%$ \\
\hline \multicolumn{8}{|l|}{ Metals, Total (composite) } \\
\hline Antimony (TSb) & $\mu \mathrm{g} / \mathrm{L}$ & 0.319 & 0.337 & 0.323 & 0.346 & -0.0234 & $-7 \%$ \\
\hline Arsenic (TAs) & $\mu \mathrm{g} / \mathrm{L}$ & 0.332 & 0.316 & 0.329 & 0.390 & -0.061 & $-19 \%$ \\
\hline Cadmium (TCd) & $\mu \mathrm{g} / \mathrm{L}$ & 0.124 & 0.130 & 0.125 & $<0.100$ & 0.0252 & $20 \%$ \\
\hline Copper (TCu) & $\mu \mathrm{g} / \mathrm{L}$ & 3.33 & 3.38 & 3.34 & 3.30 & 0.0400 & $1 \%$ \\
\hline Lead (TPb) & $\mu \mathrm{g} / \mathrm{L}$ & 1.26 & 0.864 & 1.18 & 1.22 & -0.0392 & $-3 \%$ \\
\hline Nickel (TNi) & $\mu \mathrm{g} / \mathrm{L}$ & 0.617 & 0.622 & 0.618 & 0.690 & -0.0720 & $-12 \%$ \\
\hline Zinc (TZn) & $\mu \mathrm{g} / \mathrm{L}$ & 34.9 & 34.7 & 34.9 & 25.5 & 9.36 & $27 \%$ \\
\hline \multicolumn{8}{|c|}{ Mercury Constituents - Low-level Analysis (grab) } \\
\hline Dissolved Mercury (DHg) & $\mathrm{ng} / \mathrm{L}$ & 1.2 & 0.94 & 1.2 & 1.7 & -0.50 & $-43 \%$ \\
\hline Total Mercury (THg) & $\mathrm{ng} / \mathrm{L}$ & 2.4 & 1.7 & 2.2 & 3.2 & -1.0 & $-47 \%$ \\
\hline $\begin{array}{l}\text { Dissolved Methylmercury } \\
\text { (DMeHg) }\end{array}$ & $\mathrm{ng} / \mathrm{L}$ & $<0.050$ & $<0.050$ & $<0.050$ & $<0.050$ & Indeterminate & Indeterminate \\
\hline Total Methylmercury (TMeHg) & $\mathrm{ng} / \mathrm{L}$ & 0.085 & 0.077 & 0.083 & 0.088 & -0.0046 & $-6 \%$ \\
\hline
\end{tabular}

NOTE: "I" indicates that the value is indeterminate. This may have occurred either because the influent and effluent EMCs were both below the MRL or because an elevated MRL resulted in the MRL for one sample being higher than the detectable value of the other. BOLD values are measurably different as discussed in Section 5.2.

The following mercury results refer to the low-level mercury analysis using EPA 1630 and 1631E methods only - not to the results obtained using ICPMS. During the fall event, the EMCs of DHg and $\mathrm{THg}$ and $\mathrm{TMeHg}$ increased by 42 and 45 percent, respectively. There was no change in methylmercury EMCs. The performance of the CSWQF treatment train improved with the spring event, and the treatment train reduced the EMCs of DHg by 60 percent, THg by 44 percent, DMeHg by 57 percent, and TMeHg by 64 percent. 
Table 9. Metals EMCs at the CSWQF for the spring event

\begin{tabular}{|c|c|c|c|c|c|c|c|}
\hline \multirow[b]{3}{*}{ Analyte } & \multirow[b]{3}{*}{ Unit } & \multicolumn{6}{|c|}{ 3/5/2012 Storm Event } \\
\hline & & \multicolumn{6}{|c|}{ Entire Facility } \\
\hline & & $\begin{array}{l}\text { West } \\
\text { Inlet } \\
\text { Influent } \\
\text { EMC }\end{array}$ & $\begin{array}{l}\text { East Inlet } \\
\text { Influent } \\
\text { EMC }\end{array}$ & $\begin{array}{c}\text { Total } \\
\text { Influent } \\
\text { EMC }\end{array}$ & $\begin{array}{l}\text { Effluent } \\
\text { EMC }\end{array}$ & $\begin{array}{c}\text { Difference } \\
\text { Between } \\
\text { Influent \& } \\
\text { Effluent EMC }\end{array}$ & $\begin{array}{l}\text { Percent } \\
\text { Difference }\end{array}$ \\
\hline \multicolumn{8}{|l|}{ Metals, Dissolved (composite) } \\
\hline Antimony (DSb) & $\mu \mathrm{g} / \mathrm{L}$ & 0.298 & 0.382 & 0.315 & 0.326 & -0.0112 & $-4 \%$ \\
\hline Arsenic (DAs) & $\mu \mathrm{g} / \mathrm{L}$ & 0.301 & 0.256 & 0.292 & 0.244 & 0.0480 & $16 \%$ \\
\hline Cadmium (DCd) & $\mu \mathrm{g} / \mathrm{L}$ & $<0.100$ & 0.103 & 0.101 & $<0.100$ & 0.000600 & $1 \%$ \\
\hline Copper (DCu) & $\mu \mathrm{g} / \mathrm{L}$ & 2.22 & 1.96 & 2.17 & 2.00 & 0.168 & $8 \%$ \\
\hline Lead (DPb) & $\mu \mathrm{g} / \mathrm{L}$ & 0.135 & $<0.100$ & 0.128 & $<0.100$ & 0.0280 & $22 \%$ \\
\hline Nickel (DNi) & $\mu \mathrm{g} / \mathrm{L}$ & $<0.500$ & $<0.500$ & $<0.500$ & $<0.500$ & Indeterminate & Indeterminate \\
\hline Zinc (DZn) & $\mu \mathrm{g} / \mathrm{L}$ & 40.2 & 70.8 & 46.3 & 32.3 & 14.0 & $30 \%$ \\
\hline \multicolumn{8}{|l|}{ Metals, Total (composite) } \\
\hline Antimony (TSb) & $\mu \mathrm{g} / \mathrm{L}$ & 0.512 & 0.620 & 0.534 & 0.469 & 0.0646 & $12 \%$ \\
\hline Arsenic (TAs) & $\mu \mathrm{g} / \mathrm{L}$ & 0.448 & 0.418 & 0.442 & 0.348 & 0.0940 & $21 \%$ \\
\hline Cadmium (TCd) & $\mu \mathrm{g} / \mathrm{L}$ & 0.148 & 0.191 & 0.157 & $<0.100$ & 0.0566 & $36 \%$ \\
\hline Copper (TCu) & $\mu \mathrm{g} / \mathrm{L}$ & 5.08 & 4.78 & 5.02 & 3.79 & 1.23 & $25 \%$ \\
\hline Lead (TPb) & $\mu \mathrm{g} / \mathrm{L}$ & 2.39 & 1.97 & 2.31 & 1.28 & 1.03 & $44 \%$ \\
\hline Nickel (TNi) & $\mu \mathrm{g} / \mathrm{L}$ & 1.00 & 1.13 & 1.03 & 0.663 & 0.363 & $35 \%$ \\
\hline Zinc (TZn) & $\mu \mathrm{g} / \mathrm{L}$ & 66.6 & 102 & 73.7 & 46.8 & 26.9 & $36 \%$ \\
\hline \multicolumn{8}{|l|}{ Mercury - by ICPMS (grab) } \\
\hline Total Mercury (THg) & $\mu \mathrm{g} / \mathrm{L}$ & 0.00518 & 0.00366 & 0.00488 & $<0.00200$ & 0.00288 & $59 \%$ \\
\hline \multicolumn{8}{|c|}{ Mercury Constituents - Low-level Analysis (grab) } \\
\hline Dissolved Mercury (DHg) & $\mathrm{ng} / \mathrm{L}$ & 1.7 & 1.4 & 1.6 & 0.66 & 0.98 & $60 \%$ \\
\hline Total Mercury (THg) & $\mathrm{ng} / \mathrm{L}$ & 3.7 & 4.1 & 3.8 & 2.1 & 1.7 & $44 \%$ \\
\hline $\begin{array}{l}\text { Dissolved Methylmercury } \\
\text { (DMeHg) }\end{array}$ & $\mathrm{ng} / \mathrm{L}$ & 0.11 & 0.13 & 0.11 & 0.049 & 0.065 & $57 \%$ \\
\hline Total Methylmercury (TMeHg) & $\mathrm{ng} / \mathrm{L}$ & 0.22 & 0.28 & 0.23 & 0.084 & 0.15 & $64 \%$ \\
\hline
\end{tabular}

NOTE: "I" indicates that the value is indeterminate. This may have occurred either because the influent and effluent EMCs were both below the MRL or because an elevated MRL resulted in the MRL for one sample being higher than the detectable value of the other. BOLD values are measurably different as discussed in Section 5.2.

\subsubsection{Chlorinated Herbicides, Organochlorine Pesticides, Phthalates, PAHs, and VOCs}

The following section along with Tables 10 and 11 provide information by which to assess the effectiveness of the CSWQF treatment train at removing pesticides, phthalates, PAHs, and VOCs from stormwater for the fall and spring sampling events. The treatment train decreased the EMCs of 2,4-D and pentachlorophenol for both events, with removal efficiencies ranging from 28 to 54 percent. The only measurable effect on organochlorine pesticides was the reduction of the EMC of heptachlor by 40 percent 
for the fall event. It is not possible to estimate removal efficiencies for aldrin, Endosulfan I, or endrin aldehyde for the spring event; a matrix interference during laboratory analysis of the samples led to elevated MRLs for those compounds.

The treatment train reduced the EMC of the only phthalate detected in the influent by 60 percent, with a reduction of $0.76 \mu \mathrm{g} / \mathrm{L}$. The treatment train reduced the overall EMC of PAHs between 36 and 42 percent for the two events. 6 of the 10 PAHs were measurably reduced for the fall event, and 9 of the 10 PAHs were measurably reduced for the spring event with 3 being reduced to non-detectable levels. Removal efficiencies ranged from 32 to 61 percent. Napthalene was the only PAH to show a measurable increase for the spring events, and it increased by 28 percent. No VOCs were detected in influent or effluent samples for either of the events. 
Table 10. Pesticide, phthalate, PAH, and VOC EMCs at the CSWQF for the fall event

\begin{tabular}{|c|c|c|c|c|c|c|c|}
\hline \multirow[b]{3}{*}{ Analyte } & \multirow[b]{3}{*}{ Unit } & \multicolumn{6}{|c|}{ 11/2/2011 Storm Event } \\
\hline & & \multicolumn{6}{|c|}{ Entire Facility } \\
\hline & & $\begin{array}{l}\text { West } \\
\text { Inlet } \\
\text { Influent } \\
\text { EMC }\end{array}$ & $\begin{array}{l}\text { East Inlet } \\
\text { Influent } \\
\text { EMC }\end{array}$ & $\begin{array}{l}\text { Total } \\
\text { Influent } \\
\text { EMC }\end{array}$ & $\begin{array}{l}\text { Effluent } \\
\text { EMC }\end{array}$ & $\begin{array}{c}\text { Difference } \\
\text { Between } \\
\text { Influent \& } \\
\text { Effluent EMC }\end{array}$ & $\%$ Difference \\
\hline \multicolumn{8}{|l|}{ Chlorinated Herbicides } \\
\hline $\begin{array}{l}\text { 2,4-D (Chlorophenoxy } \\
\text { Herbicide) }\end{array}$ & $\mu \mathrm{g} / \mathrm{L}$ & 0.190 & 0.0975 & 0.172 & 0.114 & 0.0575 & $34 \%$ \\
\hline Pentachlorophenol & $\mu \mathrm{g} / \mathrm{L}$ & 0.138 & 0.0769 & 0.126 & 0.0581 & 0.0677 & $54 \%$ \\
\hline Other Herbicides & $\mu \mathrm{g} / \mathrm{L}$ & ND & ND & ND & ND & -- & -- \\
\hline \multicolumn{8}{|l|}{ Organochlorine Pesticides } \\
\hline Aldrin & $\mathrm{ng} / \mathrm{L}$ & 0.64 & 0.17 & 0.55 & 0.35 & 0.20 & $36 \%$ \\
\hline Endosulfan I & $\mathrm{ng} / \mathrm{L}$ & $<0.54$ & $<0.54$ & $<0.54$ & $<0.50$ & Indeterminate & Indeterminate \\
\hline Endrin aldehyde & $\mathrm{ng} / \mathrm{L}$ & $<2.2$ & $<2.2$ & $<2.2$ & $<2.0$ & Indeterminate & Indeterminate \\
\hline Heptachlor & $\mathrm{ng} / \mathrm{L}$ & 0.54 & 2.0 & 0.83 & 0.50 & 0.33 & $40 \%$ \\
\hline Other Pesticides & $\mathrm{ng} / \mathrm{L}$ & ND & ND & ND & ND & -- & -- \\
\hline \multicolumn{8}{|l|}{ Phthalates } \\
\hline Bis(2-ethylhexyl phthalate & $\mu \mathrm{g} / \mathrm{L}$ & 1.3 & 1.1 & 1.3 & $<0.50$ & 0.80 & $62 \%$ \\
\hline Other Phthalates & $\mu \mathrm{g} / \mathrm{L}$ & ND & ND & ND & ND & -- & -- \\
\hline \multicolumn{8}{|c|}{ Polynuclear Aromatic Hydrocarbons (PAHs) } \\
\hline Total PAHs & $\mu \mathrm{g} / \mathrm{L}$ & 0.23 & 0.098 & 0.25 & 0.13 & 0.089 & $48 \%$ \\
\hline Benzo(a)anthracene & $\mu \mathrm{g} / \mathrm{L}$ & 0.012 & $<0.010$ & 0.012 & $<0.010$ & 0.0016 & $14 \%$ \\
\hline Benzo(a)pyrene & $\mu \mathrm{g} / \mathrm{L}$ & 0.011 & $<0.010$ & 0.011 & $<0.010$ & 0.00080 & $7 \%$ \\
\hline Benzo(b)fluoranthene & $\mu \mathrm{g} / \mathrm{L}$ & 0.027 & $<0.010$ & 0.024 & 0.011 & 0.013 & $53 \%$ \\
\hline Benzo(ghi)perylene & $\mu \mathrm{g} / \mathrm{L}$ & 0.024 & $<0.010$ & 0.021 & 0.011 & 0.010 & $48 \%$ \\
\hline Chrysene & $\mu \mathrm{g} / \mathrm{L}$ & 0.027 & $<0.010$ & 0.024 & 0.011 & 0.013 & $53 \%$ \\
\hline Fluoranthene & $\mu \mathrm{g} / \mathrm{L}$ & 0.029 & 0.011 & 0.025 & 0.013 & 0.012 & $49 \%$ \\
\hline Indeno(1,2,3-cd)pyrene & $\mu \mathrm{g} / \mathrm{L}$ & 0.013 & $<0.010$ & 0.012 & $<0.010$ & 0.0024 & $19 \%$ \\
\hline Naphthalene & $\mu g / L$ & $<0.040$ & 0.042 & 0.040 & 0.042 & -0.0016 & $-4 \%$ \\
\hline Phenanthrene & $\mu \mathrm{g} / \mathrm{L}$ & 0.041 & 0.027 & 0.038 & 0.022 & 0.016 & $42 \%$ \\
\hline Pyrene & $\mu \mathrm{g} / \mathrm{L}$ & 0.047 & 0.018 & 0.041 & 0.019 & 0.022 & $54 \%$ \\
\hline Other PAHs & $\mu \mathrm{g} / \mathrm{L}$ & ND & ND & ND & ND & -- & -- \\
\hline \multicolumn{8}{|c|}{ Volatile Organic Compounds (VOCs) } \\
\hline Other VOCs & $\mathrm{ng} / \mathrm{L}$ & ND & ND & ND & ND & -- & -- \\
\hline
\end{tabular}

NOTE: ND indicates that the actual value of the constituent is below the MRL and is used to represent a variety of constituents with varying MRLs. "I" indicates that the value is indeterminate. This may have occurred either because the influent and effluent EMCs were both below the MRL or because an elevated MRL resulted in the MRL for one sample being higher than the detectable value of the other. BOLD values are measurably different as discussed in Section 5.2. 
Table 11. Pesticide, phthalate, PAH, and VOC EMCs at the CSWQF for the spring event

\begin{tabular}{|c|c|c|c|c|c|c|c|}
\hline \multirow[b]{3}{*}{ Analyte } & \multirow[b]{3}{*}{ Unit } & \multicolumn{6}{|c|}{ 3/5/2012 Storm Event } \\
\hline & & \multicolumn{6}{|c|}{ Entire Facility } \\
\hline & & $\begin{array}{l}\text { West } \\
\text { Inlet } \\
\text { Influent } \\
\text { EMC }\end{array}$ & $\begin{array}{l}\text { East Inlet } \\
\text { Influent } \\
\text { EMC }\end{array}$ & $\begin{array}{l}\text { Total } \\
\text { Influent } \\
\text { EMC }\end{array}$ & $\begin{array}{l}\text { Effluent } \\
\text { EMC }\end{array}$ & $\begin{array}{c}\text { Difference } \\
\text { Between } \\
\text { Influent \& } \\
\text { Effluent EMC }\end{array}$ & \% Difference \\
\hline \multicolumn{8}{|l|}{ Chlorinated Herbicides } \\
\hline $\begin{array}{l}\text { 2,4-D (Chlorophenoxy } \\
\text { Herbicide) }\end{array}$ & $\mu \mathrm{g} / \mathrm{L}$ & 0.18 & $<0.050$ & 0.15 & 0.11 & 0.044 & $29 \%$ \\
\hline Pentachlorophenol & $\mu \mathrm{g} / \mathrm{L}$ & 0.13 & 0.045 & 0.11 & 0.081 & 0.032 & $28 \%$ \\
\hline Other Herbicides & $\mu \mathrm{g} / \mathrm{L}$ & ND & ND & ND & ND & -- & -- \\
\hline \multicolumn{8}{|l|}{ Organochlorine Pesticides } \\
\hline Aldrin & $\mathrm{ng} / \mathrm{L}$ & $<0.59$ & $<0.50$ & $<0.59$ & $<0.58$ & Indeterminate & Indeterminate \\
\hline Endosulfan I & $\mathrm{ng} / \mathrm{L}$ & $<0.59$ & 0.27 & $<0.59$ & $<0.58$ & Indeterminate & Indeterminate \\
\hline Endrin aldehyde & $\mathrm{ng} / \mathrm{L}$ & $<2.4$ & $<2.8$ & $<2.8$ & 2.0 & Indeterminate & Indeterminate \\
\hline Heptachlor & $\mathrm{ng} / \mathrm{L}$ & 1.2 & 0.67 & 1.1 & 0.68 & 0.41 & $38 \%$ \\
\hline Other Pesticides & $\mathrm{ng} / \mathrm{L}$ & ND & ND & ND & ND & -- & -- \\
\hline \multicolumn{8}{|l|}{ Phthalates } \\
\hline Bis(2-ethylhexyl phthalate & $\mu \mathrm{g} / \mathrm{L}$ & 1.2 & 1.5 & 1.3 & $<0.50$ & 0.80 & $62 \%$ \\
\hline Other Phthalates & $\mu \mathrm{g} / \mathrm{L}$ & ND & ND & ND & ND & -- & -- \\
\hline \multicolumn{8}{|c|}{ Polynuclear Aromatic Hydrocarbons (PAHs) } \\
\hline Total PAHs & $\mu \mathrm{g} / \mathrm{L}$ & 0.28 & 0.23 & 0.28 & 0.15 & 0.13 & $44 \%$ \\
\hline Benzo(a)anthracene & $\mu \mathrm{g} / \mathrm{L}$ & 0.017 & $<0.010$ & 0.016 & $<0.010$ & 0.0056 & $36 \%$ \\
\hline Benzo(a)pyrene & $\mu \mathrm{g} / \mathrm{L}$ & 0.015 & 0.013 & 0.015 & $<0.010$ & 0.0046 & $32 \%$ \\
\hline Benzo(b)fluoranthene & $\mu \mathrm{g} / \mathrm{L}$ & 0.029 & 0.021 & 0.027 & 0.011 & 0.016 & $60 \%$ \\
\hline Benzo(ghi)perylene & $\mu \mathrm{g} / \mathrm{L}$ & 0.034 & 0.027 & 0.033 & 0.013 & 0.020 & $60 \%$ \\
\hline Chrysene & $\mu \mathrm{g} / \mathrm{L}$ & 0.027 & 0.019 & 0.025 & 0.010 & 0.015 & $61 \%$ \\
\hline Fluoranthene & $\mu \mathrm{g} / \mathrm{L}$ & 0.038 & 0.045 & 0.039 & 0.017 & 0.022 & $57 \%$ \\
\hline Indeno(1,2,3-cd)pyrene & $\mu \mathrm{g} / \mathrm{L}$ & 0.015 & 0.013 & 0.015 & $<0.010$ & 0.0046 & $32 \%$ \\
\hline Naphthalene & $\mu \mathrm{g} / \mathrm{L}$ & $<0.040$ & $<0.040$ & $<0.040$ & 0.051 & -0.011 & $-28 \%$ \\
\hline Phenanthrene & $\mu \mathrm{g} / \mathrm{L}$ & 0.037 & 0.043 & 0.038 & 0.020 & 0.018 & $48 \%$ \\
\hline Pyrene & $\mu \mathrm{g} / \mathrm{L}$ & 0.071 & 0.053 & 0.067 & 0.031 & 0.036 & $54 \%$ \\
\hline Other PAHs & $\mu \mathrm{g} / \mathrm{L}$ & ND & ND & ND & ND & -- & -- \\
\hline \multicolumn{8}{|c|}{ Volatile Organic Compounds (VOCs) } \\
\hline Other VOCs & $\mathrm{ng} / \mathrm{L}$ & ND & ND & ND & ND & -- & -- \\
\hline
\end{tabular}

NOTE: ND indicates that the actual value of the constituent is below the MRL and is used to represent a variety of constituents with varying MRLs. "I" indicates that the value is indeterminate. This may have occurred either because the influent and effluent EMCs were both below the MRL or because an elevated MRL resulted in the MRL for one sample being higher than the detectable value of the other. BOLD values are measurably different as discussed in Section 5.2. 


\subsubsection{Bacteria}

Tables 12 and 13 present the results of bacteria sampling for the fall and spring events at the CSWQF. The treatment train measurably reduced the concentration of bacteria for the fall event but not for the spring event. Concentrations were considered to be different if they varied by more than half the value of the influent and effluent mean concentration (Torrey Lindbo, personal communication, April 27, 2012), and only the fall sampling event met this criteria with the EMC decreasing from 1200 to 620 colonies/mL.

Table 12. Bacteria EMCs at the CSWQF for the fall event

\begin{tabular}{|c|c|c|c|c|c|c|c|}
\hline \multirow{3}{*}{ Analyte } & \multirow{3}{*}{ Unit } & \multicolumn{6}{|c|}{ 11/2/2011 Storm Event } \\
\hline & & \multicolumn{6}{|c|}{ Entire Facility } \\
\hline & & $\begin{array}{c}\text { West Inlet } \\
\text { Influent } \\
\text { Concentration }\end{array}$ & $\begin{array}{c}\text { East Inlet } \\
\text { Influent } \\
\text { Concentration }\end{array}$ & $\begin{array}{l}\text { Total Influent } \\
\text { Concentration }\end{array}$ & $\begin{array}{c}\text { Effluent } \\
\text { Concentration }\end{array}$ & Difference & $\begin{array}{c}\% \\
\text { Difference }\end{array}$ \\
\hline \multicolumn{8}{|l|}{ Bacteria } \\
\hline E. coli - Rising Limb & MPN/100 mL & -- & -- & -- & 1300 & -- & -- \\
\hline E. coli - Peak & MPN/100 mL & 1400 & 86 & 1100 & 1000 & -- & -- \\
\hline E. coli - Falling Limb & MPN/100 mL & 1500 & 98 & 1200 & 180 & -- & -- \\
\hline $\begin{array}{l}\text { E. coli-Geometric } \\
\text { Mean }\end{array}$ & $\mathrm{MPN} / 100 \mathrm{~mL}$ & 1400 & 92 & 1200 & 620 & 580 & $48 \%$ \\
\hline
\end{tabular}

NOTE: BOLD values are measurably different as discussed in Section 5.2.

Table 13. Bacteria EMCs at the CSWQF for the spring event

\begin{tabular}{|c|c|c|c|c|c|c|c|}
\hline \multirow{2}{*}{ Analyte } & \multirow{2}{*}{ Unit } & \multicolumn{6}{|c|}{ 3/5/2012 Storm Event } \\
\hline & & \multicolumn{6}{|c|}{ Entire Facility } \\
\hline E. coli - Rising Limb & MPN/100 mL & 2300 & 85 & 1900 & 860 & -- & -- \\
\hline E. coli-Peak & MPN/100 mL & 930 & 52 & 750 & 930 & -- & -- \\
\hline E. coli - Falling Limb & MPN/100 mL & 1200 & 10 & 960 & 1000 & -- & -- \\
\hline $\begin{array}{l}\text { E. coli - Geometric } \\
\text { Mean }\end{array}$ & MPN/100 mL & 1400 & 35 & 1100 & 930 & 170 & $15 \%$ \\
\hline
\end{tabular}




\subsubsection{Field Parameters}

Table 14 shows the monitoring results for field parameters at the CSWQF for the fall event. A single reading was taken at the inlets during the rising limb of the hydrograph, and readings were taken at the facility outlet during the peak and falling limb of the hydrograph. It appears that conductivity increased, with the influent conductivity ranging from 18 to $22 \mu \mathrm{S} / \mathrm{cm}$ early in the event and then from 48 to 10 $\mu \mathrm{S} / \mathrm{cm}$ in the effluent during the latter part of the event. DO decreased after passing through the treatment train and ranged from 8.74 to $9.62 \mathrm{mg} / \mathrm{L}$ in the influent to approximately $6.21 \mathrm{mg} / \mathrm{L}$ in the effluent. Turbidity appears to have decreased from between 11.9 and 12.5 NTUs in the influent to between 7.1 and 11.7 NTUs in the effluent.

Table 14. Field parameters at the CSWQF for the fall event

\begin{tabular}{|c|c|c|c|c|}
\hline \multirow{3}{*}{ Analyte } & \multirow{3}{*}{ Unit } & \multicolumn{3}{|c|}{ 11/2/2011 Storm Event } \\
\hline & & \multicolumn{3}{|c|}{ Entire Facility } \\
\hline & & $\begin{array}{c}\text { West Inlet } \\
\text { Influent }\end{array}$ & $\begin{array}{c}\text { East Inlet } \\
\text { Influent }\end{array}$ & Effluent \\
\hline \multicolumn{5}{|l|}{ Field Parameters } \\
\hline Conductivity & $\mu S / \mathrm{cm}$ & 18 & 22 & $48-105$ \\
\hline Dissolved Oxygen (DO) & $\mathrm{mg} / \mathrm{l}$ & 8.74 & 9.62 & $6.21-6.22$ \\
\hline $\mathrm{pH}$ & -- & 7.53 & 7.17 & $6.77-7.18$ \\
\hline Temperature & ${ }^{\circ} \mathrm{C}$ & 10.15 & 9.82 & $9.16-11.69$ \\
\hline Turbidity & NTU & 12.5 & 11.9 & $11.7-7.1$ \\
\hline
\end{tabular}

NOTE: In the "Effluent" column, the first value represents the peak of the hydrograph, and the second represents the falling limb.

\subsection{FCWQF Water Quality Results}

Like the CSWQF results, the FCWQF event-specific results detailed in the following sections are meant to be illustrative in nature and do not attempt to quantify the effectiveness of the facility or its individual components in a statistically significant manner. A subset of pollutant parameters for which long-term data was available will be statistically analyzed in Section 5.3.7. For comparison purposes, the reduction in the EMC of constituents is often noted as a percent reduction. The removal efficiencies are considered "measurable" if they exceeded the analytical error associated with the laboratory testing. The 
following thresholds were used to demarcate measurable difference: 1) 10 percent for nutrients, general chemistry, and metals, 2) 20 percent for chlorinated herbicides, PAHs, and VOCs, and 3) 40 percent for organochlorine pesticides. Removal efficiencies that do not meet these criteria are not mentioned in the Results section. This method of representing removal efficiency has been justly criticized as being primarily a function of influent quality rather than BMP performance, and variations in percent removal may have little relationship to the quality of effluent that is achieved. For this reason, percent removal is provided merely as a supplement to the effluent concentrations shown in the following tables.

The tables containing the results of sampling for the CSW component and the entire treatment train show the total influent for sampling locations 3 and 5 for the CSW and sampling locations 1 and 5 for the treatment train. Tables containing separate EMC for each inlet may be found in Appendix B.

\subsubsection{Nutrients}

The following section, along with Tables 15 to 18 , provides information by which to assess the effectiveness of the FCWQF treatment train at removing nutrients from stormwater for the fall and spring sampling events. The treatment train was effective at reducing nutrient concentrations for both events, and overall nutrient removal efficiencies ranged from 21 to 34 percent. The treatment train measurably reduced the EMCs of $\mathrm{NH}_{3}-\mathrm{N}$, TKN, and TP for both events, and removal efficiencies for these pollutants ranged from 13 to 75 percent. The treatment train also reduced the EMC of OP by 23 percent for the fall event and the $\mathrm{EMC}$ of $\mathrm{NO}_{3}-\mathrm{N}$ by 45 percent for the spring event. 
Table 15. Nutrient EMCs at the SFB and WDP components of the FCWQF for the fall event

\begin{tabular}{|c|c|c|c|c|c|c|c|c|c|}
\hline \multicolumn{10}{|c|}{ 11/2/2011 Sampling Event } \\
\hline \multirow{3}{*}{ Analyte } & \multirow{3}{*}{ Unit } & \multicolumn{4}{|c|}{ SFB } & \multicolumn{4}{|c|}{ WDP } \\
\hline & & Inlet & Outlet & \multirow{2}{*}{ Difference } & \multirow{2}{*}{$\begin{array}{c}\% \\
\text { Difference }\end{array}$} & Inlet & Outlet & \multirow{2}{*}{ Difference } & \multirow{2}{*}{$\begin{array}{c}\% \\
\text { Difference }\end{array}$} \\
\hline & & 1 & 2 & & & 2 & 3 & & \\
\hline \multicolumn{10}{|l|}{ Nutrients } \\
\hline Total Nutrients & $\mathrm{mg} / \mathrm{L}$ & 0.84 & 0.86 & -0.016 & $-2 \%$ & 0.86 & 0.68 & 0.18 & $21 \%$ \\
\hline Ammonia- $\mathrm{N}\left(\mathrm{NH}_{3}-\mathrm{N}\right)$ & $\mathrm{mg} / \mathrm{L}$ & 0.075 & 0.083 & -0.0080 & $-11 \%$ & 0.083 & $<0.020$ & 0.063 & $76 \%$ \\
\hline Nitrate- $\mathrm{N}\left(\mathrm{NO}_{3}-\mathrm{N}\right)$ & $\mathrm{mg} / \mathrm{L}$ & $<0.10$ & $<0.10$ & $\mathrm{I}$ & I & $<0.10$ & $<0.10$ & $\mathrm{I}$ & $\mathrm{I}$ \\
\hline Total Kjeldahl N (TKN) & $\mathrm{mg} / \mathrm{L}$ & 0.52 & 0.52 & 0 & $0 \%$ & 0.52 & 0.44 & 0.080 & $15 \%$ \\
\hline Orthophosphate (OP) & $\mathrm{mg} / \mathrm{L}$ & 0.040 & 0.039 & 0.0010 & $3 \%$ & 0.039 & 0.030 & 0.0090 & $23 \%$ \\
\hline Total Phosphorus (TP) & $\mathrm{mg} / \mathrm{L}$ & 0.105 & 0.114 & -0.00900 & $-9 \%$ & 0.114 & 0.0880 & 0.0260 & $23 \%$ \\
\hline
\end{tabular}

NOTE: "I" indicates that the value is indeterminate. This occurred because the influent and effluent EMCs were both below the MRL. BOLD values are measurably different as discussed in Section 5.3.

Table 16. Nutrient EMCs at the CSW component and the entire FCWQF treatment train for the fall event

\begin{tabular}{|c|c|c|c|c|c|c|c|c|c|}
\hline \multicolumn{10}{|c|}{ 11/2/2011 Sampling Event } \\
\hline \multirow{3}{*}{ Analyte } & \multirow{3}{*}{ Unit } & \multicolumn{4}{|c|}{ CSW } & \multicolumn{4}{|c|}{ Entire Facility } \\
\hline & & Inlets & Outlet & & $\%$ & Inlets & Outlet & & $\%$ \\
\hline & & $3 \& 5$ & 4 & & Difference & $1 \& 5$ & 4 & 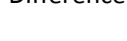 & Difference \\
\hline \multicolumn{10}{|l|}{ Nutrients } \\
\hline Total Nutrients & $\mathrm{mg} / \mathrm{L}$ & 0.71 & 0.67 & 0.044 & $6 \%$ & 0.84 & 0.67 & 0.17 & $21 \%$ \\
\hline Ammonia- $\mathrm{N}\left(\mathrm{NH}_{3}-\mathrm{N}\right)$ & $\mathrm{mg} / \mathrm{L}$ & 0.035 & $<0.020$ & 0.015 & $43 \%$ & 0.079 & $<0.020$ & 0.059 & $75 \%$ \\
\hline Nitrate- $\mathrm{N}\left(\mathrm{NO}_{3}-\mathrm{N}\right)$ & $\mathrm{mg} / \mathrm{L}$ & $<0.10$ & $<0.10$ & I & I & $<0.10$ & $<0.10$ & I & I \\
\hline Total Kjeldahl N (TKN) & $\mathrm{mg} / \mathrm{L}$ & 0.45 & 0.43 & 0.024 & $5 \%$ & 0.52 & 0.43 & 0.088 & $17 \%$ \\
\hline Orthophosphate (OP) & $\mathrm{mg} / \mathrm{L}$ & 0.032 & 0.030 & 0.0022 & $7 \%$ & 0.040 & 0.030 & 0.010 & $25 \%$ \\
\hline Total Phosphorus (TP) & $\mathrm{mg} / \mathrm{L}$ & 0.0900 & 0.0880 & 0.00240 & $3 \%$ & 0.104 & 0.0880 & 0.0160 & $15 \%$ \\
\hline
\end{tabular}

NOTE: "I" indicates that the value is indeterminate. This occurred because the influent and effluent EMCs were both below the MRL. BOLD values are measurably different as discussed in Section 5.3.

Table 17. Nutrient EMCs at the SFB and WDP components of the FCWQF for the spring event

\begin{tabular}{|c|c|c|c|c|c|c|c|c|c|}
\hline \multicolumn{10}{|c|}{ 3/5/2012 Sampling Event } \\
\hline \multirow{3}{*}{ Analyte } & \multirow{3}{*}{ Unit } & \multicolumn{4}{|c|}{ SFB } & \multicolumn{4}{|c|}{ WDP } \\
\hline & & Inlet & Outlet & \multirow{2}{*}{ Difference } & \multirow{2}{*}{$\begin{array}{c}\% \\
\text { Difference }\end{array}$} & Inlet & Outlet & \multirow{2}{*}{ Difference } & \multirow{2}{*}{ \% Difference } \\
\hline & & 1 & 2 & & & 2 & 3 & & \\
\hline \multicolumn{10}{|l|}{ Nutrients } \\
\hline Total Nutrients & $\mathrm{mg} / \mathrm{L}$ & 1.3 & 1.5 & -0.17 & $-13 \%$ & 1.5 & 0.97 & 0.52 & $35 \%$ \\
\hline Ammonia- $\mathrm{N}\left(\mathrm{NH}_{3}-\mathrm{N}\right)$ & $\mathrm{mg} / \mathrm{L}$ & 0.114 & 0.114 & 0 & $0 \%$ & 0.11 & 0.12 & -0.010 & $-9 \%$ \\
\hline Nitrate- $\mathrm{N}\left(\mathrm{NO}_{3}-\mathrm{N}\right)$ & $\mathrm{mg} / \mathrm{L}$ & 0.43 & 0.47 & -0.040 & $-9 \%$ & 0.47 & 0.28 & 0.19 & $40 \%$ \\
\hline Total Kjeldahl N (TKN) & $\mathrm{mg} / \mathrm{L}$ & 0.65 & 0.77 & -0.12 & $-18 \%$ & 0.77 & 0.47 & 0.30 & $39 \%$ \\
\hline Orthophosphate (OP) & $\mathrm{mg} / \mathrm{L}$ & $<0.020$ & $<0.020$ & I & I & $<0.020$ & $<0.020$ & I & I \\
\hline $\begin{array}{l}\text { Total Phosphorus } \\
\text { (TP) }\end{array}$ & $\mathrm{mg} / \mathrm{L}$ & 0.0950 & 0.108 & -0.0130 & $-14 \%$ & 0.108 & 0.0720 & 0.0360 & $33 \%$ \\
\hline
\end{tabular}

NOTE: "I" indicates that the value is indeterminate. This occurred because the influent and effluent EMCs were both below the MRL. BOLD values are measurably different as discussed in Section 5.3. 
Table 18. Nutrient EMCs at the CSW component and the entire FCWQF treatment train for the spring event

\begin{tabular}{|c|c|c|c|c|c|c|c|c|c|}
\hline \multicolumn{10}{|c|}{ 3/15/2012 Sampling Event } \\
\hline \multirow{3}{*}{ Analyte } & \multirow{3}{*}{ Unit } & \multicolumn{4}{|c|}{ CSW } & \multicolumn{4}{|c|}{ Entire Facility } \\
\hline & & Inlets & Outlet & \multirow{2}{*}{ Difference } & \multirow{2}{*}{$\begin{array}{c}\% \\
\text { Difference }\end{array}$} & Inlets & Outlet & \multirow{2}{*}{ Difference } & \multirow{2}{*}{ \% Difference } \\
\hline & & $3 \& 5$ & 4 & & & $1 \& 5$ & 4 & & \\
\hline \multicolumn{10}{|l|}{ Nutrients } \\
\hline Total Nutrients & $\mathrm{mg} / \mathrm{L}$ & 0.97 & 0.84 & 0.13 & $13 \%$ & 1.3 & 0.84 & 0.43 & $34 \%$ \\
\hline Ammonia- $\mathrm{N}\left(\mathrm{NH}_{3}-\mathrm{N}\right)$ & $\mathrm{mg} / \mathrm{L}$ & 0.12 & 0.096 & 0.023 & $19 \%$ & 0.11 & 0.096 & 0.014 & $13 \%$ \\
\hline Nitrate- $\mathrm{N}\left(\mathrm{NO}_{3}-\mathrm{N}\right)$ & $\mathrm{mg} / \mathrm{L}$ & 0.26 & 0.22 & 0.042 & $16 \%$ & 0.40 & 0.22 & 0.18 & $45 \%$ \\
\hline Total Kjeldahl N (TKN) & $\mathrm{mg} / \mathrm{L}$ & 0.49 & 0.44 & 0.049 & $10 \%$ & 0.65 & 0.44 & 0.21 & $32 \%$ \\
\hline Orthophosphate (OP) & $\mathrm{mg} / \mathrm{L}$ & $<0.020$ & $<0.020$ & I & I & $<0.020$ & $<0.020$ & I & I \\
\hline Total Phosphorus (TP) & $\mathrm{mg} / \mathrm{L}$ & 0.0766 & 0.0650 & 0.0116 & $15 \%$ & 0.0973 & 0.0650 & 0.0323 & $33 \%$ \\
\hline
\end{tabular}

NOTE: "I" indicates that the value is indeterminate. This occurred because the influent and effluent EMCs were both below the MRL. BOLD values are measurably different as discussed in Section 5.3.

The SFB component did not measurably reduce the EMCs of any nutrients for the two events. On the contrary, the effluent EMC of $\mathrm{NH}_{3}-\mathrm{N}$ increased by 11 percent for the fall event, and the EMCs of TKN and TP increased by 18 and 14 percent, respectively.

The greatest reduction in nutrient concentrations occurred in the WDP. The WDP measurably reduced the EMCs of TKN and TP for both events, and removal efficiencies for these pollutants ranged from 15 to 39 percent. The WDP also reduced the $\mathrm{EMC}$ of $\mathrm{NH}_{3}-\mathrm{N}$ by 76 percent and the EMC of OP by 25 percent for the fall event. The $\mathrm{EMC}$ of $\mathrm{NO}_{3}-\mathrm{N}$ decreased by 40 percent for the spring event.

Additional treatment occurred in the CSW, but removal efficiencies were lower than in the WDP. $\mathrm{NH}_{3}-\mathrm{N}$ was the only nutrient that decreased measurably for the fall event, with a reduction of 43 percent. The CSW reduced the EMCs of $\mathrm{NH}_{3}-\mathrm{N}$ by 19 percent, $\mathrm{NO}_{3}-\mathrm{N}$ by 16 percent, TKN by 10 percent, and TP by 15 percent for the spring event. The CSW did not affect concentrations of OP.

\subsubsection{General Chemistry}

Tables 19 to 22 provide information by which to assess the effectiveness of the FCWQF treatment train at removing $\mathrm{BOD}_{5}$, TOC, and TSS from stormwater for the fall and spring sampling events. The treatment train measurably reduced the EMCs of $\mathrm{BOD}_{5}$ and TSS for both events, and removal efficiencies ranged from 56 to 69 percent. Reductions in the $\mathrm{EMC}_{\text {of }} \mathrm{BOD}_{5}$ were $4 \mathrm{mg} / \mathrm{L}$ and $\mathrm{TSS}$ reductions ranged 
from 8 to $21 \mathrm{mg} / \mathrm{L}$. The treatment train also reduced the EMC of TOC by 40 percent $(2.20 \mathrm{mg} / \mathrm{L})$ for the spring event, but the EMC of TOC increased by 21 percent $(0.532 \mathrm{mg} / \mathrm{L})$ for the fall event.

Table 19. General chemistry EMCs at the SFB and WDP components of the FCWQF for the fall event

\begin{tabular}{|c|c|c|c|c|c|c|c|c|c|}
\hline \multicolumn{10}{|c|}{ 11/2/2011 Sampling Event } \\
\hline \multirow{3}{*}{ Analyte } & \multirow{3}{*}{ Unit } & \multicolumn{4}{|c|}{ SFB } & \multicolumn{4}{|c|}{ WDP } \\
\hline & & Inlet & Outlet & \multirow{2}{*}{ Difference } & \multirow{2}{*}{$\begin{array}{c}\% \\
\text { Difference }\end{array}$} & Inlet & Outlet & \multirow{2}{*}{ Difference } & \multirow{2}{*}{$\begin{array}{c}\% \\
\text { Difference }\end{array}$} \\
\hline & & 1 & 2 & & & 2 & 3 & & \\
\hline \multicolumn{10}{|l|}{ General Chemistry } \\
\hline $\mathrm{BOD}_{5}$ & $\mathrm{mg} / \mathrm{L}$ & 7 & 6 & 1 & $14 \%$ & 6 & 4 & 2 & $33 \%$ \\
\hline Total Organic Carbon (TOC) & $\mathrm{mg} / \mathrm{L}$ & 2.46 & 2.48 & -0.020 & $-1 \%$ & 2.48 & 2.86 & -0.380 & $-15 \%$ \\
\hline Total Suspended Solids (TSS) & $\mathrm{mg} / \mathrm{L}$ & 11 & 16 & -5 & $-45 \%$ & 16 & 6 & 10 & $63 \%$ \\
\hline
\end{tabular}

NOTE: BOLD values are measurably different as discussed in Section 5.3.

Table 20. General chemistry EMCs at the CSW component and the entire FCWQF treatment train for the fall event

\begin{tabular}{|c|c|c|c|c|c|c|c|c|c|}
\hline \multicolumn{10}{|c|}{ 11/2/2011 Sampling Event } \\
\hline \multirow{3}{*}{ Analyte } & \multirow{3}{*}{ Unit } & \multicolumn{4}{|c|}{ CSW } & \multicolumn{4}{|c|}{ Entire Facility } \\
\hline & & Inlets & Outlet & Difforong & $\%$ & Inlets & Outlet & Difference & $\%$ \\
\hline & & $3 \& 5$ & 4 & Dinerence & Difference & $1 \& 5$ & 4 & Dinerence & Difference \\
\hline \multicolumn{10}{|l|}{ General Chemistry } \\
\hline $\mathrm{BOD}_{5}$ & $\mathrm{mg} / \mathrm{L}$ & 4 & 3 & 1 & $32 \%$ & 7 & 3 & 4 & $56 \%$ \\
\hline Total Organic Carbon (TOC) & $\mathrm{mg} / \mathrm{L}$ & 2.91 & 3.12 & -0.212 & $-7 \%$ & 2.59 & 3.12 & -0.532 & $-21 \%$ \\
\hline Total Suspended Solids (TSS) & $\mathrm{mg} / \mathrm{L}$ & 10 & 6 & 4 & $42 \%$ & 14 & 6 & 8 & $58 \%$ \\
\hline
\end{tabular}

NOTE: BOLD values are measurably different as discussed in Section 5.3.

Table 21. General chemistry EMCs at the SFB and WDP components of the FCWQF for the spring event

\begin{tabular}{|c|c|c|c|c|c|c|c|c|c|}
\hline \multicolumn{10}{|c|}{ 3/5/2012 Sampling Event } \\
\hline \multirow{3}{*}{ Analyte } & \multirow{3}{*}{ Unit } & \multicolumn{4}{|c|}{ SFB } & \multicolumn{4}{|c|}{ WDP } \\
\hline & & Inlet & Outlet & \multirow{2}{*}{ Difference } & \multirow{2}{*}{$\begin{array}{c}\% \\
\text { Difference }\end{array}$} & Inlet & Outlet & \multirow{2}{*}{ Difference } & \multirow{2}{*}{$\begin{array}{c}\% \\
\text { Difference }\end{array}$} \\
\hline & & 1 & 2 & & & 2 & 3 & & \\
\hline \multicolumn{10}{|l|}{ General Chemistry } \\
\hline $\mathrm{BOD}_{5}$ & $\mathrm{mg} / \mathrm{L}$ & 6 & 5 & 1 & $17 \%$ & 5 & 3 & 2 & $40 \%$ \\
\hline Total Organic Carbon (TOC) & $\mathrm{mg} / \mathrm{L}$ & 5.79 & 7.31 & -1.52 & $-26 \%$ & 7.31 & 3.56 & 3.75 & $51 \%$ \\
\hline Total Suspended Solids (TSS) & $\mathrm{mg} / \mathrm{L}$ & 28 & 28 & 0 & $0 \%$ & 28 & 7 & 21 & $75 \%$ \\
\hline
\end{tabular}

NOTE: BOLD values are measurably different as discussed in Section 5.3. 
Table 22. General chemistry EMCs at the CSW component and the entire FCWQF treatment train for the spring event

\begin{tabular}{|c|c|c|c|c|c|c|c|c|c|}
\hline \multicolumn{10}{|c|}{ 3/15/2012 Sampling Event } \\
\hline \multirow{3}{*}{ Analyte } & \multirow{3}{*}{ Unit } & \multicolumn{4}{|c|}{ CSW } & \multicolumn{4}{|c|}{ Entire Facility } \\
\hline & & Inlets & Outlet & & & Inlets & Outlet & & \\
\hline & & $3 \& 5$ & 4 & Dincterte & Difference & $1 \& 5$ & 4 & Dincerte & Difference \\
\hline \multicolumn{10}{|l|}{ General Chemistry } \\
\hline $\mathrm{BOD}_{5}$ & $\mathrm{mg} / \mathrm{L}$ & 3 & 2 & 1 & $33 \%$ & 6 & 2 & 4 & $65 \%$ \\
\hline Total Organic Carbon (TOC) & $\mathrm{mg} / \mathrm{L}$ & 3.44 & 3.24 & 0.197 & $6 \%$ & 5.44 & 3.24 & 2.20 & $40 \%$ \\
\hline Total Suspended Solids (TSS) & $\mathrm{mg} / \mathrm{L}$ & 10 & 9 & 1 & $9 \%$ & 29 & 9 & 20 & $69 \%$ \\
\hline
\end{tabular}

NOTE: BOLD values are measurably different as discussed in Section 5.3.

The effectiveness of the SFB component at reducing the EMCs of TOC and TSS is not clear. The EMC of TSS increased by 45 percent for the first event but did not change for the second, and the EMC of TOC increased by 26 percent for the second event, but did not change for the first. The EMC of $\mathrm{BOD}_{5}$ decreased by $1 \mathrm{mg} / \mathrm{L}$ for both events.

The greatest reduction in the EMCs of $\mathrm{BOD}_{5}$ and TSS occurred in the WDP. The WDP measurably reduced the EMCs of $\mathrm{BOD}_{5}$ and TSS for both events, with removal efficiencies ranging from 33 to 75 percent. The EMC of $\mathrm{BOD}_{5}$ decreased by $2 \mathrm{mg} / \mathrm{L}$, and reductions in the EMC of TSS ranged from 10 to $21 \mathrm{mg} / \mathrm{L}$. The WDP also reduced the EMC of TOC by 51 percent for the spring event but did not reduce it during the fall event.

The CSW component reduced the concentration of $\mathrm{BOD}_{5}$ for both events but was less effective at removing TOC and TSS. The EMC of $\mathrm{BOD}_{5}$ decreased by an additional $1 \mathrm{mg} / \mathrm{L}$ for both events. The CSW reduced the EMC of TSS by an additional 42 percent for the first event but did not cause a measurable reduction for the second event. The EMC of TOC did not change during either event.

\subsubsection{Metals}

The following section along with Tables 23 to 26 provides information by which to assess the effectiveness of the FCWQF treatment train at removing metals from stormwater for the fall and spring sampling events. Reductions in the EMCs of individual metals (excluding non-detects) ranged from 11 to 
56 percent, and reductions in the EMCs of individual dissolved metals (excluding non-detects) ranged from 10 to 43 percent. DSb, DAs, and DCd were not analyzed in the fall event, but were later added to the sampling plan in order to improve our estimates of additional metals.

The SFB component had a measurable effect on the EMCs of individual metals with $\mathrm{TNi}$ and $\mathrm{TPb}$ increasing by 11 and 64 percent, respectively, during the first event and $\mathrm{DCu}, \mathrm{TCu}, \mathrm{DPb}, \mathrm{TPb}$, and $\mathrm{DZn}$, decreasing between 10 and 45 percent during the second event.

The WDP component reduced the EMCs of individual metals (excluding non-detects) by 18 to 79 percent, but its impact on individual dissolved metals was more mixed. The EMCs of DCu and DZn increased by 10 percent during the fall event, and the EMC of DCu increased by 10 percent during the spring event. The greatest absolute and relative reductions occurred for TZn and $\mathrm{TPb}$, respectively. $\mathrm{Cd}$ was not present at detectable levels in any of the samples for either event.

The CSW component did not have a measurable effect on concentrations of total or dissolved metals for either event. The EMCs of three individual metals changed for the fall event with TCu decreasing by 11 percent, $\mathrm{TPb}$ decreasing by 15 percent, and DZn increasing by 10 percent. The EMC of DCu decreased by 11 percent for the spring event. 
Table 23. Metal EMCs at the SFB and WDP components of the FCWQF for the fall event

\begin{tabular}{|c|c|c|c|c|c|c|c|c|c|}
\hline \multicolumn{10}{|c|}{ 11/2/2011 Sampling Event } \\
\hline \multirow{3}{*}{ Analyte } & \multirow{3}{*}{ Unit } & \multicolumn{4}{|c|}{ SFB } & \multicolumn{4}{|c|}{ WDP } \\
\hline & & Inlet & Outlet & \multirow{2}{*}{ Difference } & \multirow{2}{*}{$\begin{array}{c}\% \\
\text { Difference }\end{array}$} & Inlet & Outlet & \multirow{2}{*}{ Difference } & \multirow{2}{*}{$\begin{array}{c}\% \\
\text { Difference }\end{array}$} \\
\hline & & 1 & 2 & & & 2 & 3 & & \\
\hline \multicolumn{10}{|l|}{ Metals, Dissolved (composite) } \\
\hline Copper (DCu) & $\mu \mathrm{g} / \mathrm{L}$ & 2.37 & 2.27 & 0.100 & $4 \%$ & 2.27 & 2.49 & -0.220 & $-10 \%$ \\
\hline Lead (DPb) & $\mu \mathrm{g} / \mathrm{L}$ & 0.140 & 0.135 & 0.005 & $4 \%$ & 0.135 & $<0.100$ & 0.0350 & $26 \%$ \\
\hline Nickel (DNi) & $\mu \mathrm{g} / \mathrm{L}$ & $<0.500$ & $<0.500$ & I & I & $<0.500$ & $<0.500$ & I & I \\
\hline Zinc (DZn) & $\mu \mathrm{g} / \mathrm{L}$ & 26.7 & 27.5 & -0.800 & $-3 \%$ & 27.5 & 30.2 & -2.70 & $-10 \%$ \\
\hline \multicolumn{10}{|l|}{ Metals, Total (composite) } \\
\hline Antimony (TSb) & $\mu \mathrm{g} / \mathrm{L}$ & 0.375 & 0.400 & -0.0250 & $-7 \%$ & 0.400 & 0.287 & 0.113 & $28 \%$ \\
\hline Arsenic (TAs) & $\mu \mathrm{g} / \mathrm{L}$ & 0.377 & 0.380 & -0.00300 & $-1 \%$ & 0.380 & 0.365 & 0.015 & $4 \%$ \\
\hline Cadmium (TCd) & $\mu \mathrm{g} / \mathrm{L}$ & $<0.100$ & $<0.100$ & I & I & $<0.100$ & $<0.100$ & I & I \\
\hline Copper (TCu) & $\mu \mathrm{g} / \mathrm{L}$ & 4.65 & 4.67 & -0.0200 & $0 \%$ & 4.67 & 3.48 & 1.19 & $25 \%$ \\
\hline Lead (TPb) & $\mu \mathrm{g} / \mathrm{L}$ & 1.38 & 2.26 & -0.88 & $-64 \%$ & 2.26 & 0.476 & 1.78 & $79 \%$ \\
\hline Nickel (TNi) & $\mu \mathrm{g} / \mathrm{L}$ & 0.724 & 0.805 & -0.081 & $-11 \%$ & 0.805 & 0.500 & 0.305 & $38 \%$ \\
\hline Zinc (TZn) & $\mu \mathrm{g} / \mathrm{L}$ & 41.8 & 43.3 & -1.50 & $-4 \%$ & 43.3 & 35.7 & 7.60 & $18 \%$ \\
\hline \multicolumn{10}{|c|}{ Mercury Constituents - Low-level Analysis (grab) } \\
\hline Dissolved Mercury (DHg) & $\mathrm{ng} / \mathrm{L}$ & 2.5 & 2.4 & 0.14 & $6 \%$ & 2.4 & 1.7 & 0.66 & $28 \%$ \\
\hline Total Mercury (THg) & $\mathrm{ng} / \mathrm{L}$ & 4.2 & 4.2 & 0.070 & $2 \%$ & 4.2 & 2.9 & 1.3 & $31 \%$ \\
\hline $\begin{array}{l}\text { Dissolved Methylmercury } \\
(\mathrm{DMeHg})\end{array}$ & $\mathrm{ng} / \mathrm{L}$ & $<0.050$ & $<0.050$ & I & I & $<0.050$ & $<0.050$ & I & I \\
\hline $\begin{array}{l}\text { Total Methylmercury } \\
\text { (TMeHg) }\end{array}$ & $\mathrm{ng} / \mathrm{L}$ & 0.11 & 0.10 & 0.010 & $9 \%$ & 0.10 & 0.072 & 0.028 & $28 \%$ \\
\hline
\end{tabular}

NOTE: "I" indicates that the value is indeterminate. This may have occurred either because the influent and effluent EMCs were both below the MRL or because an elevated MRL resulted in the MRL for one sample being higher than the detectable value of the other. BOLD values are measurably different as discussed in Section 5.3. 
Table 24. Metal EMCs at the CSW component and the entire FCWQF treatment train for the fall event

\begin{tabular}{|c|c|c|c|c|c|c|c|c|c|}
\hline \multicolumn{10}{|c|}{ 11/2/2011 Sampling Event } \\
\hline \multirow{3}{*}{ Analyte } & \multirow{3}{*}{ Unit } & \multicolumn{4}{|c|}{ CSW } & \multicolumn{4}{|c|}{ Entire Facility } \\
\hline & & Inlets & Outlet & \multirow{2}{*}{ Difference } & \multirow{2}{*}{$\begin{array}{c}\% \\
\text { Difference }\end{array}$} & Inlets & Outlet & \multirow{2}{*}{ Difference } & \multirow{2}{*}{$\begin{array}{c}\% \\
\text { Difference }\end{array}$} \\
\hline & & $3 \& 5$ & 4 & & & $1 \& 5$ & 4 & & \\
\hline \multicolumn{10}{|l|}{ Metals, Dissolved (composite) } \\
\hline Copper (DCu) & $\mu g / L$ & 2.44 & 2.35 & 0.0900 & $4 \%$ & 2.34 & 2.35 & -0.00600 & $0 \%$ \\
\hline Lead (DPb) & $\mu \mathrm{g} / \mathrm{L}$ & 0.107 & $<0.100$ & 0.00660 & $6 \%$ & 0.139 & $<0.100$ & 0.0386 & $28 \%$ \\
\hline Nickel (DNi) & $\mu \mathrm{g} / \mathrm{L}$ & $<0.500$ & $<0.500$ & I & I & $<0.500$ & $<0.500$ & I & I \\
\hline Zinc (DZn) & $\mu \mathrm{g} / \mathrm{L}$ & 29.3 & 32.2 & -2.88 & $-10 \%$ & 26.5 & 32.2 & -5.68 & $-21 \%$ \\
\hline \multicolumn{10}{|l|}{ Metals, Total (composite) } \\
\hline Antimony (TSb) & $\mu \mathrm{g} / \mathrm{L}$ & 0.311 & 0.300 & 0.0110 & $4 \%$ & 0.381 & 0.300 & 0.0814 & $21 \%$ \\
\hline Arsenic (TAs) & $\mu \mathrm{g} / \mathrm{L}$ & 0.376 & 0.345 & 0.0312 & $8 \%$ & 0.386 & 0.345 & 0.0408 & $11 \%$ \\
\hline Cadmium (TCd) & $\mu \mathrm{g} / \mathrm{L}$ & $<0.100$ & $<0.100$ & I & I & $<0.100$ & $<0.100$ & I & I \\
\hline Copper (TCu) & $\mu \mathrm{g} / \mathrm{L}$ & 3.82 & 3.40 & 0.424 & $11 \%$ & 4.76 & 3.40 & 1.360 & $29 \%$ \\
\hline Lead (TPb) & $\mu \mathrm{g} / \mathrm{L}$ & 0.761 & 0.647 & 0.114 & $15 \%$ & 1.48 & 0.647 & 0.837 & $56 \%$ \\
\hline Nickel (TNi) & $\mu \mathrm{g} / \mathrm{L}$ & 0.571 & 0.579 & -0.008 & $-1 \%$ & 0.750 & 0.579 & 0.171 & $23 \%$ \\
\hline Zinc (TZn) & $\mu \mathrm{g} / \mathrm{L}$ & 37.8 & 36.5 & 1.30 & $3 \%$ & 42.7 & 36.5 & 6.180 & $14 \%$ \\
\hline \multicolumn{10}{|c|}{ Mercury Constituents - Low-level Analysis (grab) } \\
\hline Dissolved Mercury (DHg) & $\mathrm{ng} / \mathrm{L}$ & 1.7 & 2.7 & -1.0 & $-60 \%$ & 2.5 & 2.7 & -0.23 & $-9 \%$ \\
\hline Total Mercury (THg) & $\mathrm{ng} / \mathrm{L}$ & 2.9 & 3.4 & -0.51 & $-18 \%$ & 4.2 & 3.4 & 0.85 & $20 \%$ \\
\hline $\begin{array}{l}\text { Dissolved Methylmercury } \\
\text { (DMeHg) }\end{array}$ & $\mathrm{ng} / \mathrm{L}$ & $<0.050$ & $<0.050$ & I & I & $<0.050$ & $<0.050$ & I & I \\
\hline $\begin{array}{l}\text { Total Methylmercury } \\
\text { (TMeHg) }\end{array}$ & $\mathrm{ng} / \mathrm{L}$ & 0.072 & 0.079 & -0.01 & $-10 \%$ & 0.11 & 0.079 & 0.031 & $28 \%$ \\
\hline
\end{tabular}

NOTE: "I" indicates that the value is indeterminate. This may have occurred either because the influent and effluent EMCs were both below the MRL or because an elevated MRL resulted in the MRL for one sample being higher than the detectable value of the other. BOLD values are measurably different as discussed in Section 5.3. 
Table 25. Metal EMCs at the SFB and WDP components of the FCWQF for the spring event

\begin{tabular}{|c|c|c|c|c|c|c|c|c|c|}
\hline \multicolumn{10}{|c|}{ 3/5/2012 Sampling Event } \\
\hline \multirow{3}{*}{ Analyte } & \multirow{3}{*}{ Unit } & \multicolumn{4}{|c|}{ SFB } & \multicolumn{4}{|c|}{ WDP } \\
\hline & & \multirow{2}{*}{$\frac{\text { Inlet }}{1}$} & \multirow{2}{*}{$\begin{array}{c}\text { Outlet } \\
2\end{array}$} & \multirow{2}{*}{ Difference } & \multirow{2}{*}{$\begin{array}{c}\% \\
\text { Difference }\end{array}$} & \multirow{2}{*}{$\frac{\text { Inlet }}{2}$} & \multirow{2}{*}{$\begin{array}{c}\text { Outlet } \\
3\end{array}$} & \multirow{2}{*}{ Difference } & \multirow{2}{*}{$\begin{array}{c}\% \\
\text { Difference }\end{array}$} \\
\hline & & & & & & & & & \\
\hline \multicolumn{10}{|c|}{ Metals, Dissolved (composite) } \\
\hline Antimony (DSb) & $\mu \mathrm{g} / \mathrm{L}$ & 0.329 & 0.325 & 0.00400 & $1 \%$ & 0.325 & 0.219 & 0.106 & $33 \%$ \\
\hline Arsenic (DAs) & $\mu \mathrm{g} / \mathrm{L}$ & 0.234 & 0.245 & -0.0110 & $-5 \%$ & 0.245 & 0.198 & 0.0470 & $19 \%$ \\
\hline Cadmium (DCd) & $\mu \mathrm{g} / \mathrm{L}$ & $<0.100$ & $<0.100$ & I & 1 & $<0.100$ & $<0.100$ & 1 & 1 \\
\hline Copper (DCu) & $\mu \mathrm{g} / \mathrm{L}$ & 3.10 & 1.72 & 1.38 & $45 \%$ & 1.72 & 1.89 & -0.170 & $-10 \%$ \\
\hline Lead (DPb) & $\mu \mathrm{g} / \mathrm{L}$ & 0.112 & $<0.100$ & 0.0120 & $11 \%$ & $<0.100$ & $<0.100$ & 1 & 1 \\
\hline Nickel (DNi) & $\mu \mathrm{g} / \mathrm{L}$ & $<0.500$ & $<0.500$ & 1 & 1 & $<0.500$ & $<0.500$ & 1 & 1 \\
\hline Zinc (DZn) & $\mu \mathrm{g} / \mathrm{L}$ & 37.0 & 27.8 & 9.20 & $25 \%$ & 27.8 & 27.2 & 0.600 & $2 \%$ \\
\hline \multicolumn{10}{|l|}{ Metals, Total (composite) } \\
\hline Antimony (TSb) & $\mu \mathrm{g} / \mathrm{L}$ & 0.614 & 0.568 & 0.0460 & $7 \%$ & 0.568 & 0.312 & 0.256 & $45 \%$ \\
\hline Arsenic (TAs) & $\mu \mathrm{g} / \mathrm{L}$ & 0.421 & 0.394 & 0.0270 & $6 \%$ & 0.394 & 0.291 & 0.103 & $26 \%$ \\
\hline Cadmium (TCd) & $\mu \mathrm{g} / \mathrm{L}$ & $<0.100$ & $<0.100$ & I & 1 & $<0.100$ & $<0.100$ & 1 & 1 \\
\hline Copper (TCu) & $\mu \mathrm{g} / \mathrm{L}$ & 7.27 & 6.45 & 0.820 & $11 \%$ & 6.45 & 3.13 & 3.32 & $51 \%$ \\
\hline Lead (TPb) & $\mu \mathrm{g} / \mathrm{L}$ & 2.61 & 2.36 & 0.250 & $10 \%$ & 2.36 & 0.901 & 1.46 & $62 \%$ \\
\hline Nickel (TNi) & $\mu \mathrm{g} / \mathrm{L}$ & 1.21 & 1.14 & 0.0700 & $6 \%$ & 1.14 & 0.599 & 0.541 & $47 \%$ \\
\hline Zinc (TZn) & $\mu \mathrm{g} / \mathrm{L}$ & 66.5 & 61.9 & 4.60 & $7 \%$ & 61.9 & 36.5 & 25.4 & $41 \%$ \\
\hline \multicolumn{10}{|l|}{ Mercury - by ICPMS (grab) } \\
\hline Total Mercury (THg) & $\mu \mathrm{g} / \mathrm{L}$ & 0.00758 & 0.00471 & 0.00287 & $38 \%$ & 0.00471 & 0.00329 & 0.00142 & $30 \%$ \\
\hline \multicolumn{10}{|c|}{ Mercury Constituents - Low-level Analysis (grab) } \\
\hline $\begin{array}{l}\text { Dissolved Mercury } \\
(\mathrm{DHg})\end{array}$ & $\mathrm{ng} / \mathrm{L}$ & 2.6 & 2.8 & -0.20 & $-8 \%$ & 2.8 & 1.8 & 1.0 & $36 \%$ \\
\hline Total Mercury (THg) & $\mathrm{ng} / \mathrm{L}$ & 5.2 & 4.6 & 0.60 & $12 \%$ & 4.6 & 3.6 & 1.0 & $22 \%$ \\
\hline $\begin{array}{l}\text { Dissolved } \\
\text { Methylmercury } \\
\text { (DMeHg) }\end{array}$ & $\mathrm{ng} / \mathrm{L}$ & 0.11 & 0.14 & -0.030 & $-27 \%$ & 0.14 & 0.12 & 0.020 & $14 \%$ \\
\hline $\begin{array}{l}\text { Total } \\
\text { Methylmercury } \\
\text { (TMeHg) }\end{array}$ & $\mathrm{ng} / \mathrm{L}$ & 0.24 & 0.25 & -0.010 & $-4 \%$ & 0.25 & 0.27 & -0.020 & $-8 \%$ \\
\hline
\end{tabular}

NOTE: "I" indicates that the value is indeterminate. This may have occurred either because the influent and effluent EMCs were both below the MRL or because an elevated MRL resulted in the MRL for one sample being higher than the detectable value of the other. BOLD values are measurably different as discussed in Section 5.3. 
Table 26. Metal EMCs at the CSW component and the entire FCWQF treatment train for the spring event

\begin{tabular}{|c|c|c|c|c|c|c|c|c|c|}
\hline \multicolumn{10}{|c|}{ 3/15/2012 Sampling Event } \\
\hline \multirow{3}{*}{ Analyte } & \multirow{3}{*}{ Unit } & \multicolumn{4}{|c|}{ CSW } & \multicolumn{4}{|c|}{ Entire Facility } \\
\hline & & Inlets & Outlet & \multirow{2}{*}{ Difference } & \multirow{2}{*}{$\begin{array}{c}\% \\
\text { Difference }\end{array}$} & Inlets & Outlet & \multirow{2}{*}{ Difference } & \multirow{2}{*}{$\begin{array}{c}\% \\
\text { Difference }\end{array}$} \\
\hline & & $3 \& 5$ & 4 & & & $1 \& 5$ & 4 & & \\
\hline \multicolumn{10}{|c|}{ Metals, Dissolved (composite) } \\
\hline Antimony (DSb) & $\mu \mathrm{g} / \mathrm{L}$ & 0.216 & 0.210 & 0.00550 & $3 \%$ & 0.315 & 0.210 & 0.105 & $33 \%$ \\
\hline Arsenic (DAs) & $\mu \mathrm{g} / \mathrm{L}$ & 0.201 & 0.191 & 0.0104 & $5 \%$ & 0.234 & 0.191 & 0.0428 & $18 \%$ \\
\hline Cadmium (DCd) & $\mu \mathrm{g} / \mathrm{L}$ & $<0.100$ & $<0.100$ & 1 & 1 & $<0.100$ & $<0.100$ & 1 & 1 \\
\hline Copper (DCu) & $\mu \mathrm{g} / \mathrm{L}$ & 1.92 & 1.72 & 0.202 & $11 \%$ & 3.01 & 1.72 & 1.29 & $43 \%$ \\
\hline Lead (DPb) & $\mu \mathrm{g} / \mathrm{L}$ & $<0.100$ & $<0.100$ & 1 & 1 & 0.111 & $<0.100$ & 0.0108 & $10 \%$ \\
\hline Nickel (DNi) & $\mu \mathrm{g} / \mathrm{L}$ & $<0.500$ & $<0.500$ & 1 & 1 & $<0.500$ & $<0.500$ & 1 & 1 \\
\hline Zinc (DZn) & $\mu \mathrm{g} / \mathrm{L}$ & 26.8 & 27.8 & -1.04 & $-4 \%$ & 35.6 & 27.8 & 7.78 & $22 \%$ \\
\hline \multicolumn{10}{|l|}{ Metals, Total (composite) } \\
\hline Antimony (TSb) & $\mu \mathrm{g} / \mathrm{L}$ & 0.330 & 0.331 & -0.00150 & $0 \%$ & 0.601 & 0.331 & 0.270 & $45 \%$ \\
\hline Arsenic (TAs) & $\mu \mathrm{g} / \mathrm{L}$ & 0.306 & 0.292 & 0.0136 & $4 \%$ & 0.423 & 0.292 & 0.131 & $31 \%$ \\
\hline Cadmium (TCd) & $\mu \mathrm{g} / \mathrm{L}$ & $<0.100$ & $<0.100$ & 1 & I & $<0.100$ & $<0.100$ & 1 & 1 \\
\hline Copper (TCu) & $\mu \mathrm{g} / \mathrm{L}$ & 3.40 & 3.17 & 0.226 & $7 \%$ & 7.12 & 3.17 & 3.95 & $55 \%$ \\
\hline Lead (TPb) & $\mu \mathrm{g} / \mathrm{L}$ & 1.14 & 1.21 & -0.0671 & $-6 \%$ & 2.68 & 1.21 & 1.47 & $55 \%$ \\
\hline Nickel (TNi) & $\mu \mathrm{g} / \mathrm{L}$ & 0.654 & 0.665 & -0.0109 & $-2 \%$ & 1.20 & 0.665 & 0.539 & $45 \%$ \\
\hline Zinc (TZn) & $\mu \mathrm{g} / \mathrm{L}$ & 38.0 & 37.8 & 0.190 & $1 \%$ & 65.0 & 37.8 & 27.2 & $42 \%$ \\
\hline \multicolumn{10}{|l|}{ Mercury - by ICPMS (grab) } \\
\hline Total Mercury (THg) & $\mu \mathrm{g} / \mathrm{L}$ & 0.00329 & 0.00223 & 0.00106 & $32 \%$ & 0.00768 & 0.00223 & 0.00545 & $71 \%$ \\
\hline \multicolumn{10}{|c|}{ Mercury Constituents - Low-level Analysis (grab) } \\
\hline $\begin{array}{l}\text { Dissolved Mercury } \\
\text { (DHg) }\end{array}$ & $\mathrm{ng} / \mathrm{L}$ & 1.8 & 0.78 & 1.0 & $57 \%$ & 2.6 & 0.78 & 1.8 & $70 \%$ \\
\hline Total Mercury (THg) & $\mathrm{ng} / \mathrm{L}$ & 3.6 & 3.4 & 0.20 & $6 \%$ & 5.2 & 3.4 & 1.8 & $35 \%$ \\
\hline $\begin{array}{l}\text { Dissolved } \\
\text { Methylmercury } \\
\text { (DMeHg) }\end{array}$ & $\mathrm{ng} / \mathrm{L}$ & 0.12 & 0.061 & 0.059 & $49 \%$ & 0.11 & 0.061 & 0.049 & $45 \%$ \\
\hline $\begin{array}{l}\text { Total } \\
\text { Methylmercury } \\
\text { (TMeHg) }\end{array}$ & $\mathrm{ng} / \mathrm{L}$ & 0.27 & 0.14 & 0.13 & $48 \%$ & 0.24 & 0.14 & 0.10 & $42 \%$ \\
\hline
\end{tabular}

NOTE: "I" indicates that the value is indeterminate. This may have occurred either because the influent and effluent EMCs were both below the MRL or because an elevated MRL resulted in the MRL for one sample being higher than the detectable value of the other. BOLD values are measurably different as discussed in Section 5.3.

The following mercury results refer to the low-level mercury analysis using EPA 1630 and 1631E methods only - not to the results obtained using ICPMS. The FCWQF treatment train was mostly effective at reducing the EMCs of mercury constituents. DHg increased by 9 percent, but THg decreased by 20 percent for the fall event using low-level analysis. DMeHg was not present at detectable levels, and TMeHg decreased by 28 percent. DHg was removed effectively by the SFB and WDP, but a 60 percent 
increase occurred in the CSW to yield an overall increase in the treatment train. Measurable reductions in $\mathrm{THg}$ and $\mathrm{TMeHg}$ in the WDP were great enough to offset the increases of 18 and 10 percent, respectively that occurred in the CSW. DMeHg was not present at detectable levels. For the spring event, all mercury constituents measurably decreased. DHg and THg decreased by 70 and 35 percent, respectively, using low-level analysis. DMeHg and TMeHg decreased by 45 and 42 percent, respectively. Measurable removal occurred in all three components of the treatment train with the dissolved constituents being removed most effectively by the WDP and CSW, THg removal being shared by the SFB and WDP, and TMeHg occurring almost completely in the CSW. During the spring event, additional THg grab samples were collected and processed using standard lab methods rather than low-level analysis in order to compare the two methods. The treatment train reduced the THg concentrations collected in this way by 71 percent. Concentrations were reduced by 39 percent in the SFB, 30 percent in the WDP, and 32 percent in the CSW.

\subsubsection{Chlorinated Herbicides, Organochlorine Pesticides, Phthalates, PAHs, and VOCs}

The following section along with Tables 27 to 30 provides information by which to assess the effectiveness of the FCWQF treatment train at removing pesticides, phthalates, PAHs, and VOCs from stormwater for the fall and spring sampling events. The treatment train measurably reduced the EMCs of pentachlorophenol between 0.0290 and $0.0630 \mu \mathrm{g} / \mathrm{L}$, with removal efficiencies ranging from 25 to 33 percent. The WDP provided the greatest treatment with reductions ranging from 43 to 47 percent or $0.0690-0.0850 \mu \mathrm{g} / \mathrm{L}$. The EMC of pentachlorophenol actually increased measurably in the SFB and CSW components on two occasions. The treatment train reduced the EMC of 2,4-D by 26 percent for the spring event, but it increased by 45 percent for the fall event. The organochlorine pesticide gamma-BHC was reduced by 56 percent, but the treatment train failed to reduce the EMCs of alpha-BHC or endrin aldehyde. 
The treatment train reduced the EMC of the only phthalate detected in the influent by 41 to 56 percent, with reductions ranging from $0.70-1.3 \mu \mathrm{g} / \mathrm{L}$. Most of this treatment occurred in the WDP, where removal efficiencies ranged from 38 to 44 percent. The treatment train reduced the EMC of PAHs by 50 to 59 percent, with reductions ranging from $0.227-0.280 \mu \mathrm{g} / \mathrm{L} .9$ of the 11 PAHs were reduced to non-detectable levels for the fall event, and 9 of the 13 PAHs were measurably reduced for the spring event with 5 being reduced to non-detectable levels. Most of this treatment occurred in the WDP where removal efficiencies ranged from 37 to 50 percent, with reductions ranging from $0.090-0.223 \mu \mathrm{g} / \mathrm{L}$. 
Table 27. Pesticide, phthalate, PAH, and VOC EMCs at the SFB and WDP components of the FCWQF for the fall event

\begin{tabular}{|c|c|c|c|c|c|c|c|c|c|}
\hline \multicolumn{10}{|c|}{ 11/2/2011 Sampling Event } \\
\hline \multirow{3}{*}{ Analyte } & \multirow{3}{*}{ Unit } & \multicolumn{4}{|c|}{ SFB } & \multicolumn{4}{|c|}{ WDP } \\
\hline & & Inlet & Outlet & Difference & $\%$ & Inlet & Outlet & Difference & $\%$ \\
\hline & & 1 & 2 & & & 2 & 3 & & \\
\hline \multicolumn{10}{|l|}{ Chlorinated Herbicides } \\
\hline $2,4-D$ & $\mu \mathrm{g} / \mathrm{L}$ & 0.305 & 0.314 & -0.00900 & $-3 \%$ & 0.314 & 0.527 & -0.213 & $-68 \%$ \\
\hline Pentachlorophenol & $\mu g / L$ & 0.113 & 0.159 & -0.0460 & $-41 \%$ & 0.159 & 0.0900 & 0.069 & $43 \%$ \\
\hline Other Herbicides & $\mu \mathrm{g} / \mathrm{L}$ & ND & ND & -- & -- & ND & ND & -- & -- \\
\hline \multicolumn{10}{|l|}{ Organochlorine Pesticides } \\
\hline BHC, alpha- & $\mathrm{ng} / \mathrm{L}$ & 0.66 & 0.61 & 0.050 & $8 \%$ & 0.61 & $<1.2$ & I & I \\
\hline Other Pesticides & $\mathrm{ng} / \mathrm{L}$ & ND & ND & -- & -- & ND & ND & -- & -- \\
\hline \multicolumn{10}{|l|}{ Phthalates } \\
\hline Bis(2ethylhexyl)phthalate & $\mu \mathrm{g} / \mathrm{L}$ & 1.8 & 1.6 & 0.20 & $11 \%$ & 1.6 & 1.0 & 0.60 & $38 \%$ \\
\hline Other Phthalates & $\mu \mathrm{g} / \mathrm{L}$ & ND & ND & -- & -- & ND & ND & -- & -- \\
\hline \multicolumn{10}{|c|}{ Polynuclear Aromatic Hydrocarbons (PAHs) } \\
\hline Total PAHs & $\mu g / L$ & 0.41 & 0.60 & -0.19 & $-46 \%$ & 0.25 & 0.16 & 0.092 & $37 \%$ \\
\hline Benzo(a)anthracene & $\mu g / L$ & 0.015 & $<0.010$ & 0.0050 & $33 \%$ & $<0.010$ & $<0.010$ & I & I \\
\hline Benzo(a)pyrene & $\mu \mathrm{g} / \mathrm{L}$ & 0.023 & $<0.010$ & 0.013 & $57 \%$ & $<0.010$ & $<0.010$ & I & I \\
\hline Benzo(b)fluoranthene & $\mu \mathrm{g} / \mathrm{L}$ & 0.038 & 0.015 & 0.023 & $61 \%$ & 0.015 & $<0.010$ & 0.0050 & $33 \%$ \\
\hline Benzo(ghi)perylene & $\mu \mathrm{g} / \mathrm{L}$ & 0.043 & 0.027 & 0.016 & $37 \%$ & 0.027 & $<0.010$ & 0.017 & $63 \%$ \\
\hline Benzo(k)fluoranthene & $\mu \mathrm{g} / \mathrm{L}$ & 0.013 & $<0.010$ & 0.0030 & $23 \%$ & $<0.010$ & $<0.010$ & I & I \\
\hline Chrysene & $\mu \mathrm{g} / \mathrm{L}$ & 0.031 & 0.015 & 0.016 & $52 \%$ & 0.015 & $<0.010$ & 0.0050 & $33 \%$ \\
\hline Fluoranthene & $\mu \mathrm{g} / \mathrm{L}$ & 0.072 & 0.035 & 0.037 & $51 \%$ & 0.035 & 0.012 & 0.023 & $66 \%$ \\
\hline Indeno(1,2,3-cd)pyrene & $\mu \mathrm{g} / \mathrm{L}$ & 0.021 & $<0.010$ & 0.011 & $52 \%$ & $<0.010$ & $<0.010$ & I & I \\
\hline Naphthalene & $\mu \mathrm{g} / \mathrm{L}$ & 0.041 & 0.041 & 0.0 & $0 \%$ & 0.041 & $<0.040$ & 0.0010 & $2 \%$ \\
\hline Phenanthrene & $\mu \mathrm{g} / \mathrm{L}$ & 0.052 & 0.039 & 0.013 & $25 \%$ & 0.039 & $<0.020$ & 0.019 & $49 \%$ \\
\hline Pyrene & $\mu \mathrm{g} / \mathrm{L}$ & 0.063 & 0.39 & -0.33 & $-519 \%$ & 0.039 & 0.017 & 0.022 & $56 \%$ \\
\hline Other PAHs & $\mu \mathrm{g} / \mathrm{L}$ & ND & ND & -- & -- & ND & ND & -- & -- \\
\hline \multicolumn{10}{|c|}{ Volatile Organic Compounds (VOCs) } \\
\hline Other VOCs & $\mathrm{ng} / \mathrm{L}$ & ND & ND & -- & -- & ND & ND & -- & -- \\
\hline
\end{tabular}

NOTE: ND indicates that the actual value of the constituent is below the MRL and is used to represent a variety of constituents with varying MRLs. "I" indicates that the value is indeterminate. This may have occurred either because the influent and effluent EMCs were both below the MRL or because an elevated MRL resulted in the MRL for one sample being higher than the detectable value of the other. BOLD values are measurably different as discussed in Section 5.3. 
Table 28. Pesticide, phthalate, PAH, and VOC EMCs at the CSW component and the entire FCWQF treatment train for the fall event

\begin{tabular}{|c|c|c|c|c|c|c|c|c|c|}
\hline \multicolumn{10}{|c|}{ 11/2/2011 Sampling Event } \\
\hline \multirow{3}{*}{ Analyte } & \multirow{3}{*}{ Unit } & \multicolumn{4}{|c|}{ CSW } & \multicolumn{4}{|c|}{ Entire Facility } \\
\hline & & Inlets & Outlet & Difference & $\%$ & Inlets & Outlet & Difference & $\%$ \\
\hline & & $3 \& 5$ & 4 & & & $1 \& 5$ & 4 & & \\
\hline \multicolumn{10}{|l|}{ Chlorinated Herbicides } \\
\hline $2,4-D$ & $\mu \mathrm{g} / \mathrm{L}$ & 0.467 & 0.420 & 0.047 & $10 \%$ & 0.289 & 0.420 & -0.131 & $-45 \%$ \\
\hline Pentachlorophenol & $\mu \mathrm{g} / \mathrm{L}$ & 0.0958 & 0.0852 & 0.0106 & $11 \%$ & 0.114 & 0.0852 & 0.0290 & $25 \%$ \\
\hline Other Herbicides & $\mu \mathrm{g} / \mathrm{L}$ & ND & ND & -- & -- & ND & ND & -- & -- \\
\hline \multicolumn{10}{|l|}{ Organochlorine Pesticides } \\
\hline BHC, alpha- & $\mathrm{ng} / \mathrm{L}$ & I & $<0.70$ & I & I & I & $<0.70$ & I & I \\
\hline Other Pesticides & $\mathrm{ng} / \mathrm{L}$ & ND & ND & -- & -- & ND & ND & -- & -- \\
\hline \multicolumn{10}{|l|}{ Phthalates } \\
\hline Bis(2ethylhexyl)phthalate & $\mu \mathrm{g} / \mathrm{L}$ & 1.1 & $<1.0$ & 0.060 & $6 \%$ & 1.7 & $<1.0$ & 0.70 & $41 \%$ \\
\hline Other Phthalates & $\mu \mathrm{g} / \mathrm{L}$ & ND & ND & -- & -- & ND & ND & -- & -- \\
\hline \multicolumn{10}{|c|}{ Polynuclear Aromatic Hydrocarbons (PAHs) } \\
\hline Total PAHs & $\mu \mathrm{g} / \mathrm{L}$ & 0.18 & 0.16 & 0.025 & $13 \%$ & 0.39 & 0.16 & 0.23 & $59 \%$ \\
\hline Benzo(a)anthracene & $\mu \mathrm{g} / \mathrm{L}$ & $<0.010$ & $<0.010$ & I & I & 0.014 & $<0.010$ & 0.0040 & $29 \%$ \\
\hline Benzo(a)pyrene & $\mu \mathrm{g} / \mathrm{L}$ & $<0.010$ & $<0.010$ & I & I & 0.020 & $<0.010$ & 0.010 & $51 \%$ \\
\hline Benzo(b)fluoranthene & $\mu \mathrm{g} / \mathrm{L}$ & 0.011 & $<0.010$ & 0.0014 & $12 \%$ & 0.034 & $<0.010$ & 0.024 & $70 \%$ \\
\hline Benzo(ghi)perylene & $\mu \mathrm{g} / \mathrm{L}$ & 0.015 & $<0.010$ & 0.0046 & $32 \%$ & 0.041 & $<0.010$ & 0.031 & $76 \%$ \\
\hline Benzo(k)fluoranthene & $\mu \mathrm{g} / \mathrm{L}$ & $<0.010$ & $<0.010$ & I & I & 0.012 & $<0.010$ & 0.0024 & $19 \%$ \\
\hline Chrysene & $\mu \mathrm{g} / \mathrm{L}$ & 0.012 & $<0.010$ & 0.0016 & $14 \%$ & 0.028 & $<0.010$ & 0.018 & $65 \%$ \\
\hline Fluoranthene & $\mu \mathrm{g} / \mathrm{L}$ & 0.017 & 0.012 & 0.0054 & $31 \%$ & 0.065 & 0.012 & 0.053 & $82 \%$ \\
\hline Indeno(1,2,3-cd)pyrene & $\mu \mathrm{g} / \mathrm{L}$ & 0.010 & $<0.010$ & 0.0 & $0 \%$ & 0.019 & $<0.010$ & 0.0088 & $47 \%$ \\
\hline Naphthalene & $\mu \mathrm{g} / \mathrm{L}$ & 0.042 & $<0.040$ & 0.0018 & $4 \%$ & 0.043 & $<0.040$ & 0.0026 & $6 \%$ \\
\hline Phenanthrene & $\mu \mathrm{g} / \mathrm{L}$ & 0.024 & $<0.020$ & 0.0042 & $17 \%$ & 0.050 & $<0.020$ & 0.030 & $60 \%$ \\
\hline Pyrene & $\mu \mathrm{g} / \mathrm{L}$ & 0.023 & 0.017 & 0.0056 & $25 \%$ & 0.059 & 0.017 & 0.042 & $71 \%$ \\
\hline Other PAHs & $\mu \mathrm{g} / \mathrm{L}$ & ND & ND & -- & -- & ND & ND & -- & -- \\
\hline \multicolumn{10}{|c|}{ Volatile Organic Compounds (VOCs) } \\
\hline Other VOCs & $\mathrm{ng} / \mathrm{L}$ & ND & ND & -- & -- & ND & ND & -- & -- \\
\hline
\end{tabular}

NOTE: ND indicates that the actual value of the constituent is below the MRL and is used to represent a variety of constituents with varying MRLs. "I" indicates that the value is indeterminate. This may have occurred either because the influent and effluent EMCs were both below the MRL or because an elevated MRL resulted in the MRL for one sample being higher than the detectable value of the other. BOLD values are measurably different as discussed in Section 5.3.

No VOCs were detected in samples for the fall event, but the treatment train experienced a significant increase in VOC concentrations for the spring event. Although not detectable in the facility influent, chloroform appeared in the WDP at a concentration of $4.08 \mathrm{ng} / \mathrm{L}$. The CSW decreased chloroform 
concentrations by 38 percent $(1.56 \mathrm{ng} / \mathrm{L})$ but it was still present in the facility effluent at a concentration of $2.52 \mathrm{ng} / \mathrm{L}$.

Table 29. Pesticide, phthalate, PAH, and VOC EMCs at the SFB and WDP components of the FCWQF for the spring event

\begin{tabular}{|c|c|c|c|c|c|c|c|c|c|}
\hline \multirow{3}{*}{ Analyte } & \multirow{3}{*}{ Unit } & \multicolumn{4}{|c|}{ SFB } & \multicolumn{4}{|c|}{ WDP } \\
\hline & & \multirow{2}{*}{$\frac{\text { Inlet }}{1}$} & \multirow{2}{*}{$\frac{\text { Outlet }}{2}$} & \multirow{2}{*}{ Difference } & \multirow{2}{*}{$\begin{array}{c}\% \\
\text { Difference }\end{array}$} & Inlet & Outlet & \multirow{2}{*}{ Difference } & \multirow{2}{*}{$\begin{array}{c}\% \\
\text { Difference }\end{array}$} \\
\hline & & & & & & 2 & 3 & & \\
\hline \multicolumn{10}{|l|}{ Chlorinated Herbicides } \\
\hline 2,4-D (Chlorophenoxy Herbicide) & $\mu g / L$ & 0.15 & $<0.10$ & 0.050 & $33 \%$ & $<0.10$ & $<0.10$ & I & I \\
\hline Pentachlorophenol & $\mu \mathrm{g} / \mathrm{L}$ & 0.21 & 0.18 & 0.03 & $14 \%$ & 0.18 & 0.095 & 0.085 & $47 \%$ \\
\hline Other Herbicides & $\mu \mathrm{g} / \mathrm{L}$ & ND & ND & -- & -- & ND & ND & -- & -- \\
\hline \multicolumn{10}{|l|}{ Organochlorine Pesticides } \\
\hline BHC, gamma- & $\mathrm{ng} / \mathrm{L}$ & 1.6 & 1.5 & 0.10 & $6 \%$ & 1.5 & $<1.1$ & 0.40 & $27 \%$ \\
\hline Endrin aldehyde & $\mathrm{ng} / \mathrm{L}$ & $<2.3$ & $<2.3$ & I & I & $<2.3$ & 1.6 & I & I \\
\hline Other Pesticides & $\mathrm{ng} / \mathrm{L}$ & ND & ND & -- & -- & ND & ND & -- & -- \\
\hline \multicolumn{10}{|l|}{ Phthalates } \\
\hline Bis(2ethylhexyl)phthalate & $\mu g / L$ & 2.2 & 1.8 & 0.40 & $18 \%$ & 1.8 & $<1.0$ & 0.80 & $44 \%$ \\
\hline Other Phthalates & $\mu g / L$ & ND & ND & -- & -- & ND & ND & -- & -- \\
\hline \multicolumn{10}{|c|}{ Polynuclear Aromatic Hydrocarbons (PAHs) } \\
\hline Total PAHs & $\mu g / L$ & 0.51 & 0.45 & 0.061 & $12 \%$ & 0.45 & 0.23 & 0.22 & $50 \%$ \\
\hline Benzo(a)anthracene & $\mu g / L$ & 0.018 & 0.017 & 0.0010 & $6 \%$ & 0.017 & $<0.010$ & 0.0070 & $41 \%$ \\
\hline Benzo(a)pyrene & $\mu g / L$ & 0.019 & 0.016 & 0.0030 & $16 \%$ & 0.016 & $<0.010$ & 0.0060 & $38 \%$ \\
\hline Benzo(b)fluoranthene & $\mu \mathrm{g} / \mathrm{L}$ & 0.031 & 0.029 & 0.0020 & $6 \%$ & 0.029 & $<0.010$ & 0.019 & $66 \%$ \\
\hline Benzo(ghi)perylene & $\mu \mathrm{g} / \mathrm{L}$ & 0.057 & 0.049 & 0.0080 & $14 \%$ & 0.049 & 0.017 & 0.032 & $65 \%$ \\
\hline Benzo(k)fluoranthene & $\mu g / L$ & $<0.010$ & 0.010 & 0.0 & $0 \%$ & 0.010 & $<0.010$ & 0.0 & $0 \%$ \\
\hline Chrysene & $\mu \mathrm{g} / \mathrm{L}$ & 0.031 & 0.029 & 0.0020 & $6 \%$ & 0.029 & $<0.010$ & 0.019 & $66 \%$ \\
\hline Dibenzo(a,h)anthracene & $\mu \mathrm{g} / \mathrm{L}$ & $<0.010$ & $<0.010$ & I & I & $<0.010$ & $<0.010$ & I & I \\
\hline Fluoranthene & $\mu \mathrm{g} / \mathrm{L}$ & 0.086 & 0.075 & 0.011 & $13 \%$ & 0.075 & 0.024 & 0.051 & $68 \%$ \\
\hline Fluorene & $\mu g / L$ & 0.021 & 0.02 & 0.0010 & $5 \%$ & 0.020 & $<0.020$ & 0 & $0 \%$ \\
\hline Indeno(1,2,3-cd)pyrene & $\mu g / L$ & 0.019 & 0.017 & 0.0020 & $11 \%$ & 0.017 & $<0.010$ & 0.0070 & $41 \%$ \\
\hline Naphthalene & $\mu g / L$ & 0.04 & $<0.040$ & 0.0 & $0 \%$ & $<0.040$ & $<0.040$ & I & I \\
\hline Phenanthrene & $\mu g / L$ & 0.057 & 0.050 & 0.0070 & $12 \%$ & 0.050 & 0.024 & 0.026 & $52 \%$ \\
\hline Pyrene & $\mu g / L$ & 0.11 & 0.086 & 0.024 & $22 \%$ & 0.086 & 0.03 & 0.056 & $65 \%$ \\
\hline Other PAHs & $\mu \mathrm{g} / \mathrm{L}$ & ND & ND & -- & -- & ND & ND & -- & -- \\
\hline \multicolumn{10}{|l|}{ Volatile Organic Compounds (VOCs) } \\
\hline Chloroform & $\mathrm{ng} / \mathrm{L}$ & $<1.00$ & $<1.00$ & I & I & $<1.00$ & 4.08 & -3.08 & $-308 \%$ \\
\hline Other VOCs & $\mathrm{ng} / \mathrm{L}$ & ND & ND & -- & -- & ND & ND & -- & -- \\
\hline
\end{tabular}

NOTE: ND indicates that the actual value of the constituent is below the MRL and is used to represent a variety of constituents with varying MRLs. "I" indicates that the value is indeterminate. This may have occurred either because the influent and effluent EMCs were both below the MRL or because an elevated MRL resulted in the MRL for one sample being higher than the detectable value of the other. BOLD values are measurably different as discussed in Section 5.3. 
Table 30. Pesticide, phthalate, PAH, and VOC EMCs at the CSW component and the entire FCWQF treatment train for the spring event

\begin{tabular}{|c|c|c|c|c|c|c|c|c|c|}
\hline \multicolumn{10}{|c|}{ 3/15/2012 Sampling Event } \\
\hline \multirow{3}{*}{ Analyte } & \multirow{3}{*}{ Unit } & \multicolumn{4}{|c|}{ CsW } & \multicolumn{4}{|c|}{ Entire Facility } \\
\hline & & Inlets & Outlet & \multirow{2}{*}{ Difference } & \multirow{2}{*}{$\begin{array}{c}\% \\
\text { Difference }\end{array}$} & Inlets & Outlet & \multirow{2}{*}{ Difference } & \multirow{2}{*}{$\begin{array}{c}\% \\
\text { Difference }\end{array}$} \\
\hline & & $3 \& 5$ & 4 & & & $1 \& 5$ & 4 & & \\
\hline \multicolumn{10}{|l|}{ Chlorinated Herbicides } \\
\hline $2,4-D$ & $\mu \mathrm{g} / \mathrm{L}$ & $<0.10$ & $<0.10$ & I & I & 0.14 & $<0.10$ & 0.036 & $26 \%$ \\
\hline Pentachlorophenol & $\mu \mathrm{g} / \mathrm{L}$ & 0.090 & 0.13 & -0.041 & $-45 \%$ & 0.19 & 0.13 & 0.063 & $33 \%$ \\
\hline Other Herbicides & $\mu \mathrm{g} / \mathrm{L}$ & ND & ND & -- & -- & ND & ND & -- & -- \\
\hline \multicolumn{10}{|l|}{ Organochlorine Pesticides } \\
\hline BHC, gamma- & $\mathrm{ng} / \mathrm{L}$ & $<1.1$ & $<0.70$ & I & I & 1.6 & $<0.70$ & 0.90 & $56 \%$ \\
\hline Endrin aldehyde & $\mathrm{ng} / \mathrm{L}$ & 1.6 & 2.2 & -0.60 & $-38 \%$ & $<2.3$ & 2.2 & I & I \\
\hline Other Pesticides & $\mathrm{ng} / \mathrm{L}$ & ND & ND & -- & -- & ND & ND & -- & -- \\
\hline \multicolumn{10}{|l|}{ Phthalates } \\
\hline Bis(2ethylhexyl)phthalate & $\mu \mathrm{g} / \mathrm{L}$ & 1.18 & 1.0 & 0.18 & $15 \%$ & 2.3 & 1.0 & 1.3 & $56 \%$ \\
\hline Other Phthalates & $\mu \mathrm{g} / \mathrm{L}$ & ND & ND & -- & -- & ND & ND & -- & -- \\
\hline \multicolumn{10}{|c|}{ Polynuclear Aromatic Hydrocarbons (PAHs) } \\
\hline Total PAHs & $\mu \mathrm{g} / \mathrm{L}$ & 0.31 & 0.28 & 0.027 & $9 \%$ & 0.57 & 0.28 & 0.28 & $50 \%$ \\
\hline Benzo(a)anthracene & $\mu g / L$ & 0.013 & $<0.010$ & 0.0029 & $22 \%$ & 0.020 & $<0.010$ & 0.010 & $50 \%$ \\
\hline Benzo(a)pyrene & $\mu \mathrm{g} / \mathrm{L}$ & 0.015 & 0.012 & 0.0027 & $18 \%$ & 0.023 & 0.012 & 0.011 & $47 \%$ \\
\hline Benzo(b)fluoranthene & $\mu \mathrm{g} / \mathrm{L}$ & 0.020 & 0.018 & 0.0020 & $10 \%$ & 0.039 & 0.018 & 0.021 & $54 \%$ \\
\hline Benzo(ghi)perylene & $\mu \mathrm{g} / \mathrm{L}$ & 0.027 & 0.026 & 0.0013 & $5 \%$ & 0.063 & 0.026 & 0.037 & $59 \%$ \\
\hline Benzo(k)fluoranthene & $\mu \mathrm{g} / \mathrm{L}$ & 0.012 & $<0.010$ & 0.0020 & $17 \%$ & 0.012 & $<0.010$ & 0.0020 & $17 \%$ \\
\hline Chrysene & $\mu \mathrm{g} / \mathrm{L}$ & 0.018 & 0.015 & 0.0025 & $14 \%$ & 0.036 & 0.015 & 0.021 & $59 \%$ \\
\hline Dibenzo(a,h)anthracene & $\mu \mathrm{g} / \mathrm{L}$ & 0.011 & $<0.010$ & 0.00070 & $7 \%$ & 0.011 & $<0.010$ & 0.00070 & $7 \%$ \\
\hline Fluoranthene & $\mu \mathrm{g} / \mathrm{L}$ & 0.041 & 0.037 & 0.0036 & $9 \%$ & 0.096 & 0.037 & 0.059 & $62 \%$ \\
\hline Fluorene & $\mu \mathrm{g} / \mathrm{L}$ & 0.020 & $<0.020$ & 0.00010 & $0 \%$ & 0.021 & $<0.020$ & 0.0010 & $5 \%$ \\
\hline Indeno(1,2,3-cd)pyrene & $\mu g / L$ & 0.015 & 0.012 & 0.0029 & $19 \%$ & 0.023 & 0.012 & 0.011 & $48 \%$ \\
\hline Naphthalene & $\mu \mathrm{g} / \mathrm{L}$ & 0.041 & $<0.040$ & 0.00090 & $2 \%$ & 0.041 & $<0.040$ & 0.00090 & $2 \%$ \\
\hline Phenanthrene & $\mu \mathrm{g} / \mathrm{L}$ & 0.031 & 0.027 & 0.0044 & $14 \%$ & 0.061 & 0.027 & 0.034 & $56 \%$ \\
\hline Pyrene & $\mu \mathrm{g} / \mathrm{L}$ & 0.046 & 0.045 & 0.0010 & $2 \%$ & 0.12 & 0.045 & 0.073 & $62 \%$ \\
\hline Other PAHs & $\mu \mathrm{g} / \mathrm{L}$ & ND & ND & -- & -- & ND & ND & -- & -- \\
\hline \multicolumn{10}{|c|}{ Volatile Organic Compounds (VOCs) } \\
\hline Chloroform & $\mathrm{ng} / \mathrm{L}$ & 4.08 & 2.52 & 1.56 & $38 \%$ & $<1.00$ & 2.52 & -1.52 & $-152 \%$ \\
\hline Other VOCs & $\mathrm{ng} / \mathrm{L}$ & ND & ND & -- & -- & ND & ND & -- & -- \\
\hline
\end{tabular}

NOTE: "ND" indicates that the actual value of the constituent is below the MRL and is used to represent a variety of constituents with varying MRLs. "I" indicates that the value is indeterminate. This may have occurred either because the influent and effluent EMCs were both below the MRL or because an elevated MRL resulted in the MRL for one sample being higher than the detectable value of the other. BOLD values are measurably different as discussed in Section 5.3. 


\subsubsection{Bacteria}

Tables 31 to 34 show the results of bacteria sampling for the fall and spring events at the FCWQF. The treatment train effectively reduced the concentration of bacteria for the spring event but not for the fall event. Concentrations were considered to be different if they varied by more than half of value of the influent and effluent mean concentration (Torrey Lindbo, personal communication, April 27, 2012). For the spring event, the EMC of E. coli decreased by 290 colonies/100 mL, exceeding the half-mean value of 272 colonies $/ 100 \mathrm{~mL}$. The WDP component was the only cell of the treatment train to measurably reduce bacteria concentrations. The WDP reduced the concentration by 42 percent for the fall event and 40 percent for the spring event.

Table 31. Bacteria concentrations at the SFB and WDP components of the FCWQF for the fall event

\begin{tabular}{|c|c|c|c|c|c|c|c|c|c|}
\hline \multicolumn{10}{|c|}{ 11/2/2011 Sampling Event } \\
\hline \multirow{3}{*}{ Analyte } & \multirow{3}{*}{ Unit } & \multicolumn{4}{|c|}{ SFB } & \multicolumn{4}{|c|}{ WDP } \\
\hline & & Inlet & Outlet & Difforence & $\%$ & Inlet & Outlet & Difforence & $\%$ \\
\hline & & 1 & 2 & Dirterence & Difference & 2 & 3 & Dimerence & Difference \\
\hline \multicolumn{10}{|l|}{ Bacteria } \\
\hline E. coli - Rising Limb & $\mathrm{MPN} / 100 \mathrm{~mL}$ & 5200 & 2600 & -- & -- & 2600 & 3900 & -- & -- \\
\hline E. coli - Peak & MPN/100 mL & 3700 & 4400 & -- & -- & 4400 & 1700 & -- & -- \\
\hline E. coli - Falling Limb & MPN/100 mL & 1900 & 3900 & -- & -- & 3900 & 1300 & -- & -- \\
\hline $\begin{array}{l}\text { E. coli-Geometric } \\
\text { Mean }\end{array}$ & $\mathrm{MPN} / 100 \mathrm{~mL}$ & 3300 & 3500 & -230 & $-7 \%$ & 3500 & 2100 & 1500 & $42 \%$ \\
\hline
\end{tabular}

NOTE: BOLD values are measurably different as discussed in Section 5.3.

Table 32. Bacteria concentrations at the CSW component and the entire FCWQF treatment train for the fall event

\begin{tabular}{|c|c|c|c|c|c|c|c|c|c|}
\hline \multicolumn{10}{|c|}{ 11/2/2011 Sampling Event } \\
\hline \multirow{3}{*}{ Analyte } & \multirow{3}{*}{ Unit } & \multicolumn{4}{|c|}{ CSW } & \multicolumn{4}{|c|}{ Entire Facility } \\
\hline & & Inlets & Outlet & & & Inlets & Outlet & & $\%$ \\
\hline & & $3 \& 5$ & 4 & 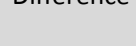 & Difference & $1 \& 5$ & 4 & 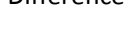 & Difference \\
\hline \multicolumn{10}{|l|}{ Bacteria } \\
\hline E. coli - Rising Limb & MPN/100 mL & 3800 & 3900 & -- & -- & 4800 & 3900 & -- & -- \\
\hline E. coli - Peak & MPN/100 mL & 2000 & 2000 & -- & -- & 3600 & 2000 & -- & -- \\
\hline E. coli - Falling Limb & MPN/100 mL & 1400 & 1100 & -- & -- & 1800 & 1100 & -- & -- \\
\hline E. coli - Geometric Mean & MPN/100 mL & 2200 & 2000 & 150 & $7 \%$ & 3200 & 2000 & 1100 & $36 \%$ \\
\hline
\end{tabular}


Table 33. Bacteria concentrations at the SFB and WDP components of the FCWQF for the spring event

\begin{tabular}{|c|c|c|c|c|c|c|c|c|c|}
\hline \multicolumn{10}{|c|}{ 3/5/2012 Sampling Event } \\
\hline \multirow{3}{*}{ Analyte } & \multirow{3}{*}{ Unit } & \multicolumn{4}{|c|}{ SFB } & \multicolumn{4}{|c|}{ WDP } \\
\hline & & Inlet & Outlet & \multirow{2}{*}{ Difference } & \multirow{2}{*}{$\begin{array}{c}\% \\
\text { Difference }\end{array}$} & Inlet & Outlet & \multirow{2}{*}{ Difference } & \multirow{2}{*}{$\begin{array}{c}\% \\
\text { Difference }\end{array}$} \\
\hline & & 1 & 2 & & & 2 & 3 & & \\
\hline \multicolumn{10}{|l|}{ Bacteria } \\
\hline E. coli - Rising Limb & MPN/100 mL & 800 & 1400 & -- & -- & 1400 & 770 & -- & -- \\
\hline E. coli - Peak & MPN/100 mL & 750 & 680 & -- & -- & 680 & 600 & -- & -- \\
\hline E. coli - Falling Limb & $\mathrm{MPN} / 100 \mathrm{~mL}$ & 500 & 740 & -- & -- & 740 & 330 & -- & -- \\
\hline E. coli - Geometric Mean & MPN/100 mL & 670 & 890 & -220 & $-33 \%$ & 890 & 530 & 360 & $40 \%$ \\
\hline
\end{tabular}

NOTE: BOLD values are measurably different as discussed in Section 5.3.

Table 34. Bacteria concentrations at the CSW component and the entire FCWQF treatment train for the spring event

\begin{tabular}{|c|c|c|c|c|c|c|c|c|c|}
\hline \multicolumn{10}{|c|}{ 3/5/2012 Sampling Event } \\
\hline \multirow{3}{*}{ Analyte } & \multirow{3}{*}{ Unit } & \multicolumn{4}{|c|}{ CSW } & \multicolumn{4}{|c|}{ Entire Facility } \\
\hline & & Inlets & Outlet & 0.0 & $\%$ & Inlets & Outlet & Drce & \\
\hline & & $3 \& 5$ & 4 & Dinerence & Difference & $1 \& 5$ & 4 & Dinerence & Difference \\
\hline \multicolumn{10}{|l|}{ Bacteria } \\
\hline E. coli - Rising Limb & $\mathrm{MPN} / 100 \mathrm{~mL}$ & 790 & 550 & -- & -- & 820 & 550 & -- & -- \\
\hline E. coli - Peak & $\mathrm{MPN} / 100 \mathrm{~mL}$ & 600 & 480 & -- & -- & 730 & 480 & -- & -- \\
\hline E. coli - Falling Limb & $\mathrm{MPN} / 100 \mathrm{~mL}$ & 330 & 170 & -- & -- & 500 & 170 & -- & -- \\
\hline E. coli-Geometric Mean & MPN/100 mL & 540 & 360 & 190 & $34 \%$ & 670 & 360 & 290 & $47 \%$ \\
\hline
\end{tabular}

NOTE: BOLD values are measurably different as discussed in Section 5.3.

\subsubsection{Field Parameters}

Field parameters were collected for the fall event but not for the spring event. The results of that event are show in Tables 35 and 36. The FCWQF treatment train reduced DO with influent concentrations ranging from 6.92 to $10.81 \mathrm{mg} / \mathrm{L}$ in the influent to approximately 6.26 to $6.47 \mathrm{mg} / \mathrm{L}$ in the effluent. Turbidity appears to have decreased from between 10.0 and 11.1 NTUs in the influent to around 6.0 NTUs in the effluent. These changes largely occurred in the WDP component of the treatment train with additional changes occurring in the CSW to a lesser degree. 
Table 35. Field parameters at the SFB and WDP components of the FCWQF for the fall event

\begin{tabular}{|c|c|c|c|c|c|}
\hline \multicolumn{6}{|c|}{ 11/2/2011 Sampling Event } \\
\hline \multirow{3}{*}{ Analyte } & \multirow{3}{*}{ Unit } & \multicolumn{2}{|c|}{ SFB } & \multicolumn{2}{|c|}{ WDP } \\
\hline & & Inlet & Outlet & Inlet & Outlet \\
\hline & & 1 & 2 & 2 & 3 \\
\hline \multicolumn{6}{|l|}{ Field Parameters } \\
\hline Conductivity & $\mu S / \mathrm{cm}$ & $42-23$ & $13-23$ & $13-23$ & $23-37$ \\
\hline $\begin{array}{l}\text { Dissolved Oxygen } \\
\text { (DO) }\end{array}$ & $\mathrm{mg} / \mathrm{L}$ & $10.81-6.92$ & $11.63-7.21$ & $11.63-7.21$ & $7.19-6.46$ \\
\hline $\mathrm{pH}$ & -- & $7.47-7.11$ & $7.11-6.99$ & $7.11-6.99$ & $6.92-7.02$ \\
\hline Temperature & ${ }^{\circ} \mathrm{C}$ & $9.91-10.36$ & $9.92-9.99$ & $9.92-9.99$ & $8.56-11.57$ \\
\hline Turbidity & NTU & $11.1-10.0$ & $12.7-8.8$ & $12.7-8.8$ & $6.41-6.85$ \\
\hline
\end{tabular}

NOTE: The "Effluent" column contains 2 values. The first value represents the peak of the hydrograph, and the second represents the falling limb.

Table 36. Field parameters at the CSW component and the entire FCWQF treatment train for the fall event

\begin{tabular}{|c|c|c|c|c|c|c|c|}
\hline \multicolumn{8}{|c|}{ 11/2/2011 Sampling Event } \\
\hline \multirow{3}{*}{ Analyte } & \multirow{3}{*}{ Unit } & \multicolumn{3}{|c|}{ CSW } & \multicolumn{3}{|c|}{ Entire Facility } \\
\hline & & \multicolumn{2}{|c|}{ Inlets } & Outlet & \multicolumn{2}{|c|}{ Inlets } & Outlet \\
\hline & & 3 & 5 & 4 & 1 & 5 & 4 \\
\hline \multicolumn{8}{|l|}{ Field Parameters } \\
\hline Conductivity & $\mu \mathrm{S} / \mathrm{cm}$ & $23-37$ & -- & $26-33$ & $42-23$ & -- & $26-33$ \\
\hline $\begin{array}{l}\text { Dissolved Oxygen } \\
\text { (DO) }\end{array}$ & $\mathrm{mg} / \mathrm{L}$ & $7.19-6.46$ & -- & $6.26-6.47$ & $10.81-6.92$ & -- & $6.26-6.47$ \\
\hline $\mathrm{pH}$ & -- & $6.92-7.02$ & -- & $7.12-6.68$ & $7.47-7.11$ & -- & $7.12-6.68$ \\
\hline Temperature & ${ }^{\circ} \mathrm{C}$ & $8.56-11.57$ & -- & $7.74-11.52$ & $9.91-10.36$ & -- & $7.74-11.52$ \\
\hline Turbidity & NTU & $6.41-6.85$ & -- & $5.7-6.0$ & $11.1-10.0$ & -- & $5.7-6.0$ \\
\hline
\end{tabular}

NOTE: The "Effluent" column contains 2 values. The first value represents the peak of the hydrograph, and the second represents the falling limb.

\subsubsection{Long-Term Statistical Analysis}

As described in Section 3.4, a dataset containing EMC data for 21 parameters was analyzed to determine if the FCWQF treatment train significantly reduced concentrations of pollutants. The specific sampling events contained in the dataset for each parameter are shown in Table 3.

The size of the dataset is sufficient to meet the assumptions of the Wilcoxon Signed Rank test which will be used to compare the influent and effluent EMCs. As stated in Section 3.4, the Wilcoxon Signed Rank test is a non-parametric statistical hypothesis test used when comparing two related samples to assess whether one of the two samples tends to have larger values than the other. It is often used as an alternative to the paired Student's t-test when analyzing environmental data because this data is often not normally distributed. The hypothesis for the one-tailed test is as follows: 


\section{$\mathrm{H}_{\mathrm{o}}$ : median influent EMC < = median effluent EMC \\ $\mathrm{H}_{\mathrm{a}}$ : median influent EMC > median effluent EMC}

The critical value for the test was based upon an alpha of 0.05. The results of the Wilcoxon Signed Rank test are presented in Table 37.

Table 37. Wilcoxon Signed Rank test results for parameters at the FCWQF

\begin{tabular}{|c|c|c|c|c|c|c|c|}
\hline Analyte & Unit & $\begin{array}{c}\text { Median } \\
\text { Influent EMC }\end{array}$ & $\begin{array}{c}\text { Influent } \\
\text { Sample } \\
\text { Size }\end{array}$ & $\begin{array}{c}\text { Median } \\
\text { Effluent EMC }\end{array}$ & $\begin{array}{c}\text { Effluent } \\
\text { Sample } \\
\text { Size }\end{array}$ & $\mathrm{p}$-Value & Results \\
\hline \multicolumn{8}{|l|}{ Nutrients } \\
\hline Ammonia- $\mathrm{N}\left(\mathrm{NH}_{3}-\mathrm{N}\right)$ & $\mathrm{mg} / \mathrm{L}$ & 0.10 & 8 & 0.073 & 8 & 0.00391 & Decrease \\
\hline Nitrate- $\mathrm{N}\left(\mathrm{NO}_{3}-\mathrm{N}\right)$ & $\mathrm{mg} / \mathrm{L}$ & 0.18 & 8 & 0.19 & 8 & 0.777 & $\begin{array}{c}\text { No Significant } \\
\text { Decrease }\end{array}$ \\
\hline $\begin{array}{l}\text { Total Kjeldahl } \\
\text { Nitrogen (TKN) }\end{array}$ & $\mathrm{mg} / \mathrm{L}$ & 0.63 & 8 & 0.45 & 8 & 0.00391 & Decrease \\
\hline Orthophosphate (OP) & $\mathrm{mg} / \mathrm{L}$ & 0.028 & 8 & 0.022 & 8 & 0.223 & $\begin{array}{c}\text { No Significant } \\
\text { Decrease }\end{array}$ \\
\hline Total Phosphorus (TP) & $\mathrm{mg} / \mathrm{L}$ & 0.0987 & 8 & 0.0850 & 8 & 0.0742 & Potential Decrease \\
\hline
\end{tabular}

General Chemistry

\begin{tabular}{|l|l|c|c|c|c|c|c|c|}
\hline & BOD $_{5}$ & $\mathrm{mg} / \mathrm{L}$ & 5 & 8 & 3 & 8 & $\mathbf{0 . 0 1 1}$ & Decrease \\
\cline { 2 - 8 } & $\begin{array}{l}\text { Total Suspended } \\
\text { Solids (TSS) }\end{array}$ & $\mathrm{mg} / \mathrm{L}$ & 16 & 8 & 6 & 8 & $\mathbf{0 . 0 0 3 9 1}$ & Decrease \\
\hline
\end{tabular}

Dissolved Metals
\begin{tabular}{|l|l|c|c|c|c|c|c|}
\hline Copper (DCu) & $\mu \mathrm{g} / \mathrm{L}$ & 2.88 & 8 & 2.40 & 8 & 0.125 & Potential Decrease \\
\hline Lead (DPb) & $\mu \mathrm{g} / \mathrm{L}$ & 0.169 & 8 & 0.165 & 8 & 0.104 & Potential Decrease \\
\hline Zinc (DZn) & $\mu \mathrm{g} / \mathrm{L}$ & 34.0 & 8 & 28.2 & 8 & $\mathbf{0 . 0 2 7 3}$ & Decrease \\
\hline
\end{tabular}

\begin{tabular}{|c|c|c|c|c|c|c|c|}
\hline \multicolumn{8}{|l|}{ Total Metals } \\
\hline Copper (TCu) & $\mu \mathrm{g} / \mathrm{L}$ & 5.98 & 8 & 3.52 & 8 & 0.00391 & Decrease \\
\hline Lead (TPb) & $\mu \mathrm{g} / \mathrm{L}$ & 2.39 & 8 & 0.820 & 8 & 0.00391 & Decrease \\
\hline Nickel (TNi) & $\mu \mathrm{g} / \mathrm{L}$ & 0.980 & 8 & 0.668 & 8 & 0.00391 & Decrease \\
\hline Zinc (TZn) & $\mu g / L$ & 53.6 & 8 & 37.2 & 8 & 0.00391 & Decrease \\
\hline \multicolumn{8}{|l|}{ Bacteria } \\
\hline E. coli & MPN/100mL & 930 & 21 & 560 & 23 & 0.0251 & Decrease \\
\hline \multicolumn{8}{|l|}{ Field Parameters } \\
\hline Conductivity & $\mu S / \mathrm{cm}$ & 30 & 38 & 44 & 39 & 0.999 & $\begin{array}{c}\text { No Significant } \\
\text { Decrease }\end{array}$ \\
\hline Dissolved Oxygen (DO) & $\mathrm{mg} / \mathrm{L}$ & 8.04 & 38 & 7.76 & 40 & 0.0776 & Potential Decrease \\
\hline $\mathrm{pH}$ & -- & 7.13 & 35 & 7.1 & 39 & 0.261 & $\begin{array}{c}\text { No Significant } \\
\text { Decrease }\end{array}$ \\
\hline Temperature & ${ }^{\circ} \mathrm{C}$ & 10.2 & 38 & 9.7 & 40 & 0.47 & $\begin{array}{c}\text { No Significant } \\
\text { Decrease }\end{array}$ \\
\hline Turbidity & NTU & 18.8 & 34 & 11.3 & 34 & 0.00303 & Decrease \\
\hline
\end{tabular}


Of the 20 parameters for which long-term monitoring data was available, 11 were significantly reduced in concentration by the treatment train. These are the parameters for which the null hypothesis was rejected and are indicated by the word "Decrease" in the Results column of the table. Analysis of $\mathrm{NH}_{3}-\mathrm{N}, \mathrm{TKN}, \mathrm{BOD}_{5}, \mathrm{TSS}, \mathrm{DZn}, \mathrm{TCu}, \mathrm{TPb}, \mathrm{TNi}, \mathrm{TZn}$, E. coli, and turbidity resulted in a rejection of the null hypothesis that the median influent EMC is less than or equal to the median effluent EMC. EMCs for these parameters are statistically lower in the facility effluent than the influent. An additional four parameters were potentially reduced by the treatment train although they were not statistically lower. The Wilcoxon Signed Rank test produced p-values of 0.150 or less for $\mathrm{TP}, \mathrm{DCu}, \mathrm{DPb}$, and $\mathrm{DO}$ showing that there is a potential difference between their median influent and effluent EMCs. In the case of DO, a potential decrease in concentration may be a negative effect of the treatment train.

\subsection{DISCUSSION}

The Discussion section will focus on a comparison of the long-term and event-based sampling results at the Fairview Creek Water Quality Facility, a comparison of removal efficiencies at the Columbia Slough and Fairview Creek Water Quality Facilities, possible reasons for the differences in fall and spring removal efficiencies, and the limitations inherent in the study.

\subsection{Comparison of Long-term and Event-based Results at the FCWQF}

All three components of the FCWQF treatment train were designed to facilitate the removal of sediment and other particulates that are initially suspended in the water column. The treatment train design uses slow flow velocities, long retention times, and contact with emergent vegetation to remove particulates. As would be expected, the treatment train effectively reduced the EMCs of suspended sediment and other pollutants associated with particulates. Over the 12 sampling events for which data are available, the median EMC of TSS decreased from $16 \mathrm{mg} / \mathrm{L}$ to $5.5 \mathrm{mg} / \mathrm{L}$ - a reduction of 66 percent. Likewise, the median turbidity decreased from 18.8 NTUs to 11.3 NTUs, or 40 percent. 
The International Stormwater BMP Database (BMP Database) is a database of over 400 BMP studies and provides performance analysis results for stormwater BMPs. These BMPs include retention ponds and wetland basins that are similar to those used in the FCWQF treatment train. Median influent and effluent EMCs for the FCWQF treatment train, retention ponds in the BMP Database, and wetland basins in the BMP Database are shown in Table 38.

Table 38. Influent and effluent EMCs for the FCWQF and the BMP Database

\begin{tabular}{|c|c|c|c|c|c|c|c|}
\hline Analyte & Unit & $\begin{array}{l}\text { Median } \\
\text { Influent } \\
\text { EMC }(n=) \\
\text { - FCWQF }\end{array}$ & $\begin{array}{c}\text { Median } \\
\text { Influent } \\
\text { EMC ( } n=)- \\
\text { BMP } \\
\text { Database } \\
\text { (Retention } \\
\text { Pond) }\end{array}$ & $\begin{array}{c}\text { Median } \\
\text { Influent } \\
\text { EMC ( } n=) \text { - } \\
\text { BMP } \\
\text { Database } \\
\text { (Wetland } \\
\text { Basin) }\end{array}$ & $\begin{array}{l}\text { Median } \\
\text { Effluent } \\
\text { EMC ( } n=) \\
\text { - FCWQF }\end{array}$ & $\begin{array}{c}\text { Median } \\
\text { Effluent } \\
\text { EMC ( } n=)- \\
\text { BMP } \\
\text { Database } \\
\text { (Retention } \\
\text { Pond) }\end{array}$ & $\begin{array}{c}\text { Median } \\
\text { Effluent } \\
\text { EMC ( } n=)- \\
\text { BMP } \\
\text { Database } \\
\text { (Wetland } \\
\text { Basin) }\end{array}$ \\
\hline \multicolumn{8}{|l|}{ Nutrients } \\
\hline Total Kjeldahl Nitrogen (TKN) & $\mathrm{mg} / \mathrm{L}$ & $0.63(8)$ & $1.3(371)$ & $1.1(67)$ & $0.45(8)$ & $0.99(376)$ & $1.1(176)$ \\
\hline Orthophosphate (OP) & $\mathrm{mg} / \mathrm{L}$ & $0.028(8)$ & $0.11(362)$ & 0.05 (179) & $0.022(8)$ & $0.04(346)$ & $0.02(171)$ \\
\hline Total Phosphorus (TP) & $\mathrm{mg} / \mathrm{L}$ & $0.099(8)$ & $0.27(578)$ & $0.12(284)$ & $0.085(8)$ & $0.11(561)$ & $0.08(271)$ \\
\hline \multicolumn{8}{|l|}{ General Chemistry } \\
\hline Total Suspended Solids (TSS) & $\mathrm{mg} / \mathrm{L}$ & $16(8)$ & $60(605)$ & $20(300)$ & $6(8)$ & 12 (605) & $8(289)$ \\
\hline \multicolumn{8}{|l|}{ Dissolved Metals } \\
\hline Copper (DCu) & $\mu g / L$ & $2.88(8)$ & $7.5(214)$ & $5.9(28)$ & $2.40(8)$ & $5.0(223)$ & $5.0(25)$ \\
\hline Lead (DPb) & $\mu \mathrm{g} / \mathrm{L}$ & $0.169(8)$ & $1.8(195)$ & $1.0(28)$ & $0.165(8)$ & $1.5(201)$ & $1.0(25)$ \\
\hline Zinc (DZn) & $\mu \mathrm{g} / \mathrm{L}$ & $34.0(8)$ & $23.3(193)$ & $44.6(28)$ & $28.2(8)$ & $10.0(203)$ & $19.1(25)$ \\
\hline \multicolumn{8}{|l|}{ Total Metals } \\
\hline Copper (TCu) & $\mu \mathrm{g} / \mathrm{L}$ & $5.98(8)$ & $10.0(468)$ & $6.12(152)$ & $3.52(8)$ & $6.0(468)$ & $4.0(148)$ \\
\hline Lead (TPb) & $\mu \mathrm{g} / \mathrm{L}$ & 2.39 (8) & $10.0(572)$ & $2.0(124)$ & $0.82(8)$ & $3.0(560)$ & $1.0(121)$ \\
\hline Nickel (TNi) & $\mu \mathrm{g} / \mathrm{L}$ & $0.98(8)$ & $6.0(124)$ & NA & $0.67(8)$ & $2.8(121)$ & NA \\
\hline Zinc (TZn) & $\mu \mathrm{g} / \mathrm{L}$ & $53.6(8)$ & $52.8(501)$ & $51.8(177)$ & $37.2(8)$ & $20.0(509)$ & $20.0(170)$ \\
\hline \multicolumn{8}{|l|}{ Field Parameters } \\
\hline Turbidity & NTU & $18.8(34)$ & $17(89)$ & NA & $11.3(34)$ & $1(102)$ & NA \\
\hline
\end{tabular}

NOTE: BOLD values indicate that the effluent EMC is significantly different than the influent EMC. Values in parentheses indicate sample size.

According to the BMP Database's Pollutant Category Summary for Solids, the retention ponds within the dataset reduced the median EMC of TSS from $60 \mathrm{mg} / \mathrm{L}$ in the influent to $12 \mathrm{mg} / \mathrm{L}$ in the effluent, and wetland basins reduced the median EMC from 20 to $8 \mathrm{mg} / \mathrm{L}$ (Leisenring et al., 2011). The FCWQF outperformed the BMPs in the BMP Database by reducing the effluent EMC of TSS to $5.5 \mathrm{mg} / \mathrm{L}$. Retention ponds and wetland basins in the BMP database reduced turbidity levels from a median influent 
turbidity of 17 NTUs to a median effluent turbidity of 1 NTU. The FCWQF did not perform as well in this respect. Though the turbidity of influent was comparable, the median effluent turbidity at the FCWQF was 11.3 NTUs.

The results of the two individual sampling events at the FCWQF follow the same trends as the longterm data set. The individual event EMCs for TSS and turbidity are shown in comparison to the long-term data distributions in Figure 5. The data from the individual treatment train components suggest that the SFB did not reduce TSS concentrations. While the CSW component contributed to TSS reductions, the WDP reduced TSS to the greatest extent. The WDP was the only component for which a measurable decrease in TSS was apparent in the effluent during both events. However, that does not necessarily mean that the SFB is ineffective at reducing the sediment load of stormwater. In reality, regular maintenance is required to remove the large amounts of sediment that accumulate. Although the concentration of TSS was not significantly reduced during the monitored storm events, the concentrations of larger particles, which do not necessarily contribute to TSS, are reduced by the SFB.

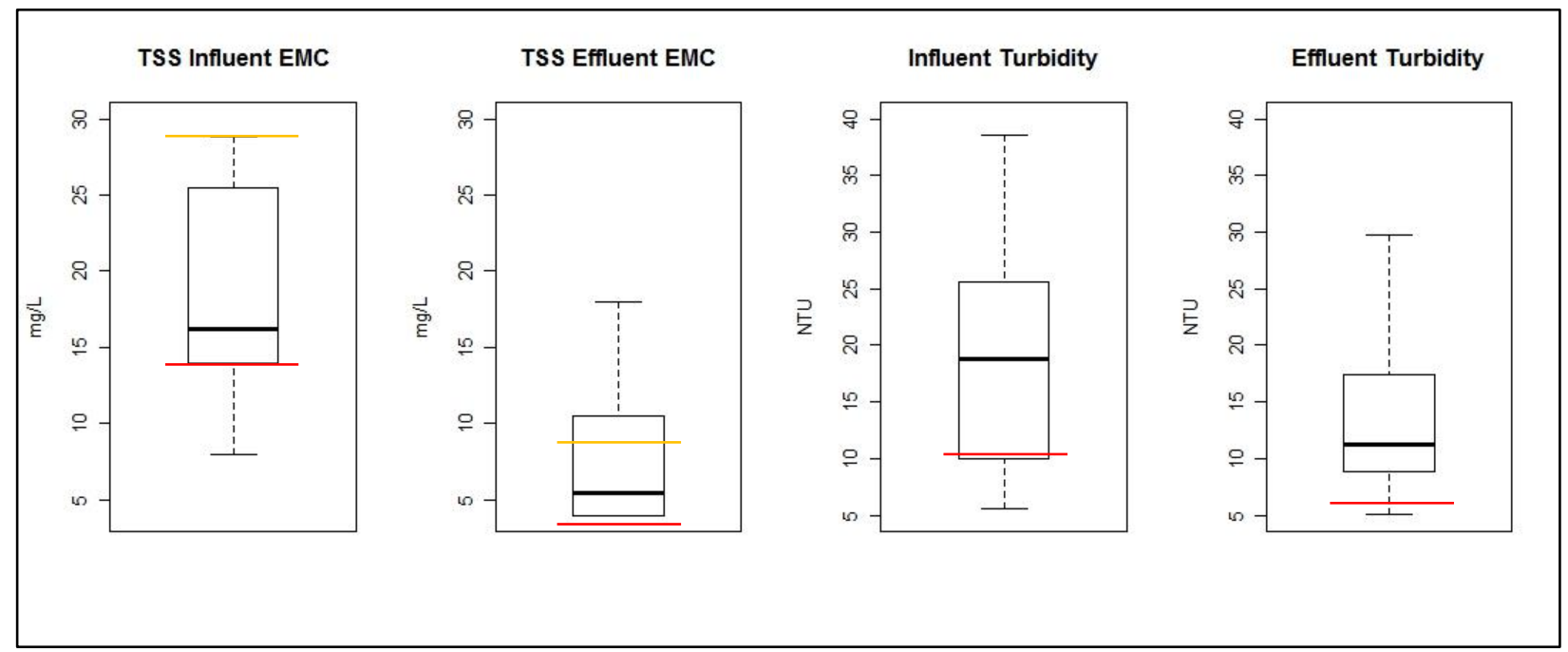

Figure 5. Distribution of TSS and Turbidity (11/2/2011 event ; 3/5/2012 event)

Wet detention ponds and constructed wetlands are capable of achieving high removal efficiencies for many metals, and this retention of metals occurs through a combination of sedimentation, adsorption to particulate matter, and uptake by emergent vegetation (Maine et al., 2006; Vymazal et al., 1998a; Yeh, 
2008). Total metals are removed by all three of the above processes. The results of the statistical analysis indicate that the treatment train significantly reduced the EMCs of total copper, lead, nickel, and zinc. The median EMCs of TCu, TNi, TPb, and TZn decreased by 41, 66, 32, and 31 percent, respectively.

With the exception of TZn, the FCWQF's long-term median effluent EMCs fall below those found in the BMP Database Pollutant Category Summary for Metals. FCWQF median effluent EMCs decreased to $3.52 \mu \mathrm{g} / \mathrm{L}$ for $\mathrm{TCu}, 0.668 \mu \mathrm{g} / \mathrm{L}$ for $\mathrm{TNi}, 0.820 \mu \mathrm{g} / \mathrm{L}$ for $\mathrm{TPb}$, and $37.2 \mu \mathrm{g} / \mathrm{L}$ for $\mathrm{TZn}$. According to the BMP Database, retention ponds and wetland basins reduced median effluent EMCs to $4.0 \mu \mathrm{g} / \mathrm{L}$ for $\mathrm{TCu}$, $2.8 \mu \mathrm{g} / \mathrm{L}$ for TNi, $1.0 \mu \mathrm{g} / \mathrm{L}$ for $\mathrm{TPb}$, and $20.0 \mu \mathrm{g} / \mathrm{L}$ for TZn (Clary et al., 2011). The fact that the median effluent EMCs at the FCWQF are generally lower than those in the BMP Database summary may in large part be due to the presence of lower median influent EMCs and are not necessarily an indicator of the facility's superior effectiveness. Table 38 demonstrates that although the median effluent EMCs of $\mathrm{TCu}$, $\mathrm{TPb}$, and TNi at the FCWQF were lower than the median effluent EMC of similar BMPs, the median influent EMCs of these pollutants were also less than the value of similar BMPs. The FCWQF's lower effluent values may be a result of cleaner influent rather than greater removal efficiency.

The results of the two individual sampling events at the FCWQF follow the same trend as the longterm data set, with concentrations of all individual metals decreasing by similar percentages. The individual event EMCs for total metals are shown in comparison to the long-term data distributions in Figure 6. As was the case for TSS, the data from the individual treatment train components suggest that the WDP is responsible for the greatest reductions in total metals. The WDP had the greatest removal efficiencies for almost all metals during both sampling events. With that said, the pollutant removal effectiveness of the CSW has likely been underestimated due to the direct inputs of untreated stormwater that entered through the secondary inlet during both sampling events. However, the differences in removal efficiency between the WDP and CSW are great enough that the WDP would likely have a higher removal efficiency regardless of whether or not the secondary inlet was active during the event. 


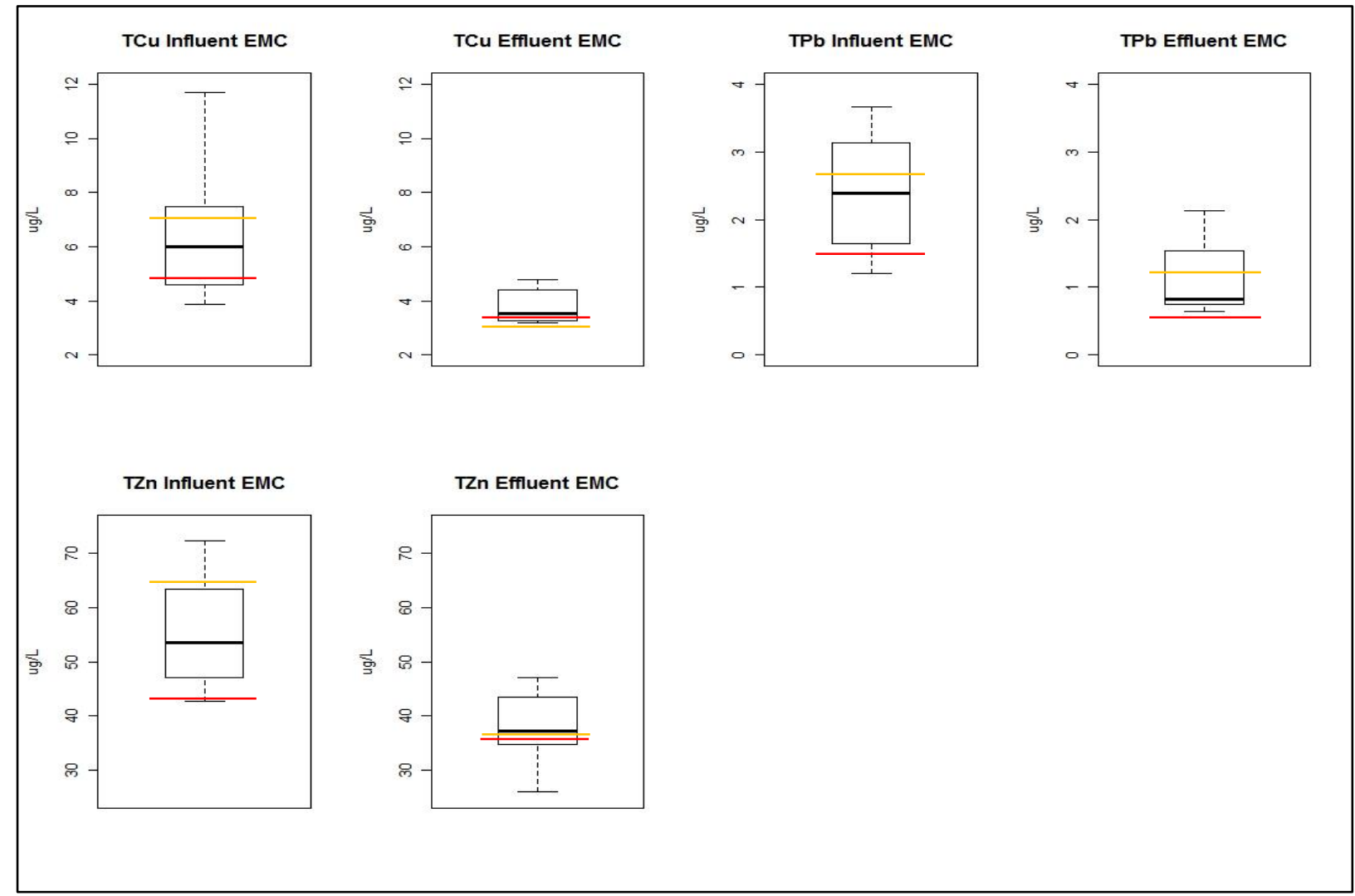

Figure 6. Distribution of Total Metals EMCs (11/2/2011 event ; 3/5/2012 event)

In contrast to total metals, dissolved metals are not susceptible to sedimentation but are primarily removed through adsorption and uptake by vegetation (Vymazal et al., 1998). The efficiency of detention ponds and constructed wetlands at removing dissolved metals is quite variable and is affected by detention and contact times, remobilization of sediment, and seasonal vegetation effects (Carlisle \& Mulamoottil, 1991; Yeh, 2008). The results of the statistical analysis indicate that the treatment train significantly reduced the median EMC of DZn by 17 percent $(5.8 \mu \mathrm{g} / \mathrm{L})$ but did not significantly affect the EMCs of DCu or DPb. According to the FCWQF long-term data, the median influent and effluent EMCs are statistically similar for the other dissolved metals. The median EMCs of DCu and DPb were potentially reduced by the treatment train, but these reductions were not significant at an $\alpha$ of 0.05 .

With the exception of DZn, the FCWQF's long-term median effluent EMCs fall below those found in the BMP Database's Pollutant Category Summary for Metals. Although not significantly reduced by the FCWQF treatment train, the median effluent EMCs of $\mathrm{DCu}(2.40 \mu \mathrm{g} / \mathrm{L})$ and $\mathrm{DPb}(0.165 \mu \mathrm{g} / \mathrm{L})$ were 
lower than those reported in the BMP Database of $5.0 \mu \mathrm{g} / \mathrm{L}$ and $1.0 \mu \mathrm{g} / \mathrm{L}$, respectively (Clary et al., 2011).

The results of the two individual sampling events provided similar pictures of the treatment train's effectiveness, with the EMCs of all dissolved metals except DZn decreasing between 10 and 43 percent. The EMC of DZn increased by 21 percent for the fall event but decreased by 22 percent for the spring event. The individual event EMCs for dissolved metals are shown in comparison to the long-term data distributions in Figure 7. Although not statistically significant, it is interesting to note that the SFB although not very effective at reducing total metals concentrations - was responsible for the greatest reductions in the EMCs of DCu, DPb, and DZn. During the fall event, the SFB reduced the EMC of DPb

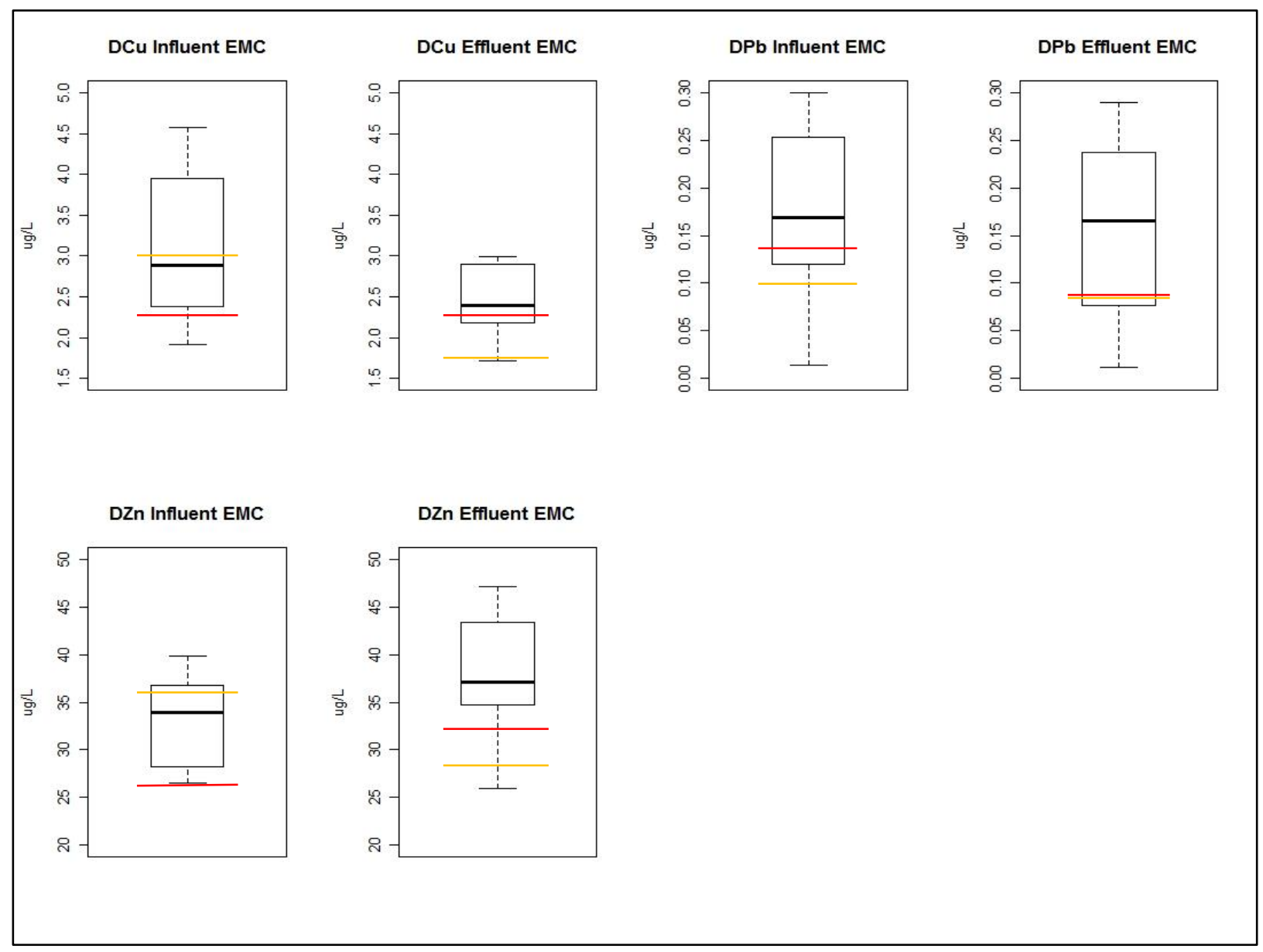

Figure 7. Distribution of Dissolved Metals EMCs (11/2/2011 event ; 3/5/2012 event) 
by 26 percent. This was the only measurable reduction in the concentration of a dissolved metal to occur. During the spring event, the SFB reduced the EMCs of DCu, DPb, and DZn by 45, 11, and 25 percent, respectively. The WDP reduced the EMCs of DSb and DCd by 33 and 19 percent but did not measurably reduce the concentrations of other dissolved metals. The CSW reduced the EMC of DCu by an additional 11 percent.

In theory, sedimentation and organic matter storage in the WDP and CSW components of the treatment train should be responsible for reducing the EMCs of PAHs throughout the facility. The sorption of hydrophobic pollutants on sediment particles is well-documented, and increases in organic carbon content facilitating further sorption (Karickhoff et al., 1978; Diblasi et al., 2009). This appears to be the case for most of the PAHs found in the influent. The absence of a flow-weighted influent EMC lends ambiguity to some of the data, but 19 of the 24 PAH EMCs decreased measurably. When the removal effectiveness is broken down by treatment train component, the results follow the trend set by TSS. The WDP was the most effective component of the facility and reduced concentrations of total PAHs by an average of $0.223 \mu \mathrm{g} / \mathrm{L}$ for the spring event versus $0.061 \mu \mathrm{g} / \mathrm{L}$ for the SFB and $0.111 \mu \mathrm{g} / \mathrm{L}$ for the CSW. Theoretically, the process of sedimentation should also reduce pesticide concentrations (Schulz $\&$ Peall, 2001), but the data from the two sampling events is inconclusive on this point.

One would also expect to see significant reductions in the EMCs of nutrients due to the variety of removal mechanisms present in the components of the treatment train. The mixture of microbial environments provided by the CSW should aid in the removal of $\mathrm{NH}_{3}-\mathrm{N}$ and $\mathrm{TKN}$ through nitrification and $\mathrm{NO}_{3}-\mathrm{N}$ through the denitrification that occurs under anoxic conditions. TP and OP should be removed primarily through sedimentation as facilitated by all three components (Wadzuk et al., 2010). Additionally, vegetative uptake should further reduce concentrations of these pollutants (Vymazal et al., 1998a). However, the long-term analysis shows that the treatment train significantly reduced the concentration of only two nutrients. The median $\mathrm{EMCs}$ of $\mathrm{NH}_{3}-\mathrm{N}$ and $\mathrm{TKN}$ were significantly reduced by 30 and 29 percent, respectively. Although the median $\mathrm{EMC}$ of $\mathrm{NO}_{3}-\mathrm{N}$ did not decrease significantly, this 
is not proof against the facility's ability to remove $\mathrm{NO}_{3}-\mathrm{N}$ through denitrification. $\mathrm{NO}_{3}-\mathrm{N}$ is a product of the nitrification process that removes $\mathrm{NH}_{3}-\mathrm{N}$ from stormwater. One would expect that the significant reduction in the $\mathrm{EMC}$ of $\mathrm{NH}_{3}-\mathrm{N}$ would lead to a corresponding increase in the $\mathrm{EMC}$ of $\mathrm{NO}_{3}-\mathrm{N}$. However, the fact that the EMC of $\mathrm{NO}_{3}-\mathrm{N}$ did not significantly change indicates that the facility is perhaps just as efficient at removing $\mathrm{NO}_{3}-\mathrm{N}$ as it is at removing $\mathrm{NH}_{3}-\mathrm{N}$; the process of denitrification is removing as much $\mathrm{NO}_{3}-\mathrm{N}$ as the process of nitrification is creating. The median EMC of TP decreased by 14 percent, and the results of the Wilcoxon Signed Rank test yielded a p-value of 0.0742 . There was a potential reduction in the median EMC of TP, but it was not significant at an $\alpha$ of 0.05 .

The FCWQF's long-term median effluent EMCs for nutrients compare favorably with those found in the BMP Database's Pollutant Category Summary for Nutrients (Leisenring et al., 2010). The FCWQF median effluent EMC of $0.45 \mathrm{mg} / \mathrm{L}$ for TKN was lower than the median effluent value of $1.1 \mathrm{mg} / \mathrm{L}$ reported by the BMP Database for retention ponds and wetland basins. The FCWQF median effluent EMCs of $0.022 \mathrm{mg} / \mathrm{L}$ for OP and $0.085 \mathrm{mg} / \mathrm{L}$ for TP were lower than the median effluent values reported by the BMP Database for retention ponds but not for wetland basins. In the BMP Database, the median effluent EMC of OP was $0.04 \mathrm{mg} / \mathrm{L}$ for retention ponds and $0.02 \mathrm{mg} / \mathrm{L}$ for wetland basins, and the median effluent EMC of TP was $0.11 \mathrm{mg} / \mathrm{L}$ for retention ponds and $0.08 \mathrm{mg} / \mathrm{L}$ for wetland basins. The fact that the median effluent EMCs at the FCWQF are lower than those in the BMP Database summary may in large part be due to the presence of lower median influent EMCs and are not necessarily an indicator of the facility's superior effectiveness. Table 38 demonstrates that although the median effluent EMCs of TKN, OP, and TP at the FCWQF were sometimes as low as half the median effluent EMC of similar BMPs, the median influent EMCs of these pollutants were also half the value of similar BMPs. The FCWQF's lower effluent values may be a result of cleaner influent rather than greater removal efficiency.

The results of the two individual sampling events are similar for $\mathrm{NH}_{3}-\mathrm{N}$, TKN, and TP with these parameters decreasing measurably. The measurable reductions recorded for the remainder of the nutrients were not statistically significant in the long-term dataset. The individual event EMCs for nutrients are 
shown in comparison to the long-term data distributions in Figure 8. Again, the majority of the reductions occurred in the WDP component. In contrast, the SFB did not remove any nutrients. The CSW reduced all nutrients except OP, but these reductions were relatively small compared to those of the WDP.

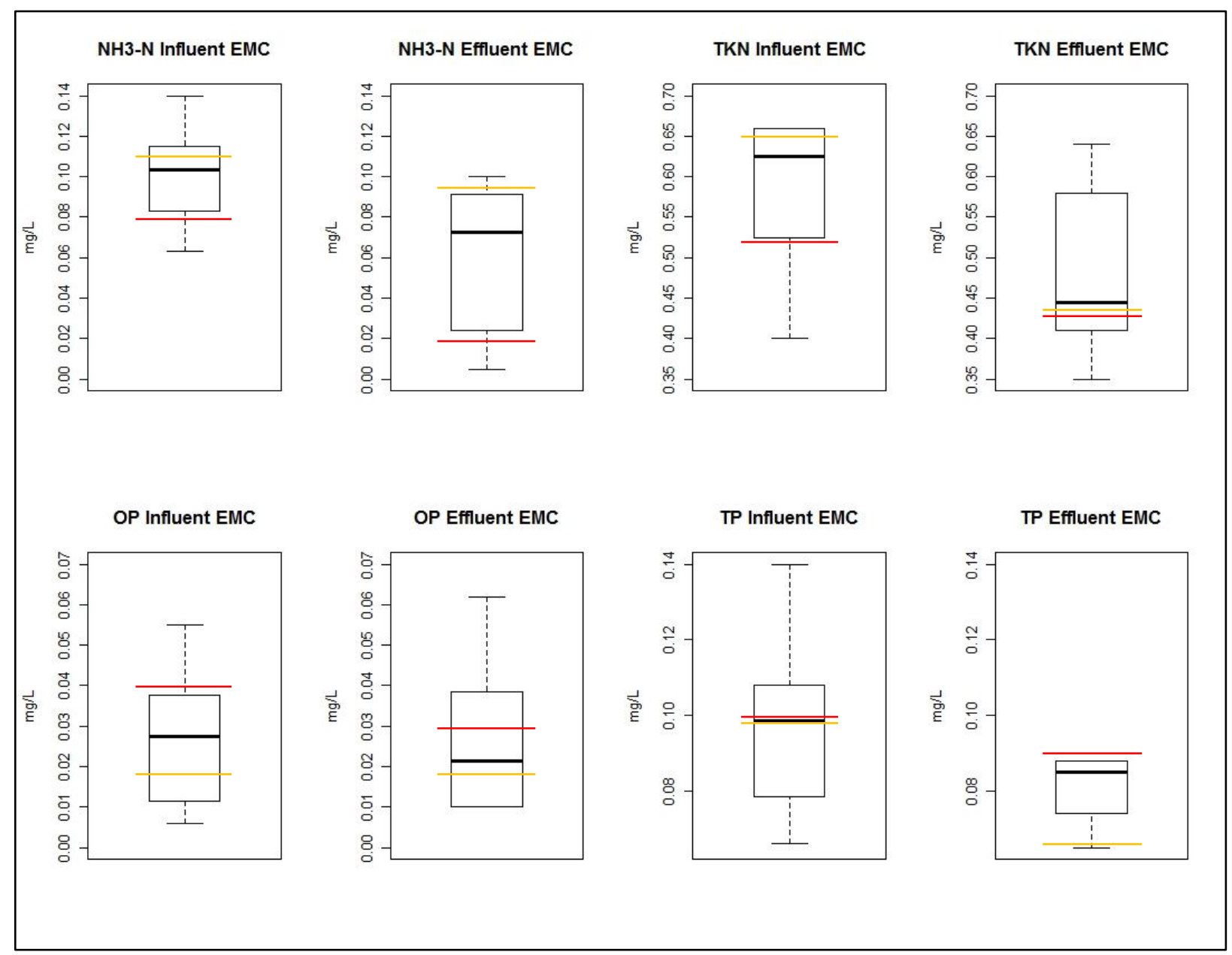

Figure 8. Distribution of Nutrient EMCs (11/2/2011 event ; 3/5/2012 event)

Analysis of the long-term data shows that the treatment train effectively removed bacteria from the influent. The median EMC of E. coli decreased from 930 to 560 colonies/100mL or by 40 percent. This reduction is both statistically significant and meets the bacteria criteria set forth in Section 5.2.5 Bacteria. The FCWQF's long-term median effluent EMC for bacteria could not be compared to the studies found in the BMP Database's Pollutant Category Summary for Fecal Indicator Bacteria (Clary et al., 2010). The BMP Database's studies had a sufficient number of samples to analyze facility performance with respect to fecal coliform but not E. coli, which was this study's bacterial indicator. 
The results of the spring event followed the long-term data trend, but there was no measurable reduction in the EMC of E. coli for the fall event. The individual event EMCs for E.coli are shown in comparison to the long-term data distributions in Figure 9. It is not possible to determine where the greatest reduction in the concentration of E. coli occurred because none of the treatment train components measurably reduced E. coli during either event.

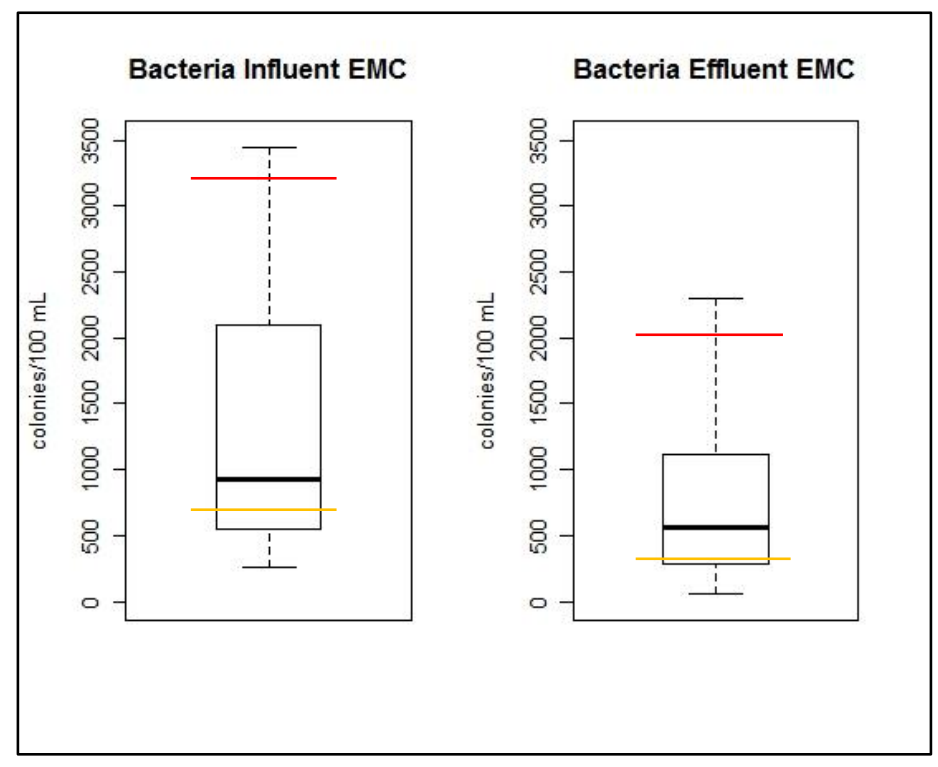

Figure 9. Distribution of Bacteria EMCs (11/2/2011 event ; 3/5/2012

\subsection{Comparison of Treatment Train Removal Efficiencies}

Removal efficiencies for the CSWQF were lower than those at the FCWQF for most pollutants for the fall sampling event but were more similar for the spring event. Nutrient concentrations increased by 46 percent $(0.43 \mathrm{mg} / \mathrm{L})$ at the CSWQF for the fall event but measurably decreased by 11 percent in the spring event. In contrast, the FCWQF reduced nutrient concentrations by 21 percent $(0.17 \mathrm{mg} / \mathrm{L})$ and 32 percent $(0.40 \mathrm{mg} / \mathrm{L})$ for the two events. The CSWQF performed somewhat better with regard to metals. Removal efficiencies for dissolved metals during the two events were 32 percent $(9.30 \mu \mathrm{g} / \mathrm{L})$ and 29 percent $(14.3 \mu \mathrm{g} / \mathrm{L})$ in comparison to 20 percent $(7.70 \mu \mathrm{g} / \mathrm{L})$ and an increase of 19 percent $(5.65 \mu \mathrm{g} / \mathrm{L})$ at the FCWQF. Removal efficiencies for total metals during the two events at the CSWQF were somewhat 
different than those at the FCWQF, with no measurable change occurring in the fall and a mean removal efficiency of 29 percent in the spring. For comparison, the FCWQF had a mean metal removal efficiency of 26 percent in the fall and 45 percent in the spring. Mercury and methymercury removal efficiencies were mixed with the CSWQF outperforming the FCWQF in the spring but not causing a reduction in mercury constituents in the fall. The CSWQF was slightly more effective at reducing phthalate concentrations with an efficiency of 60 percent versus 41 to 56 percent at the FCWQF. PAH concentrations decreased measurably (36 to 42 percent) but not to the same extent as at the FCWQF where they decreased 55 to 59 percent.

Although this may appear to support the claim that the FCWQF treatment train is more effective than the CSWQF treatment train at removing nutrients and organic compounds, this is not necessarily the case. When influent concentrations at the two facilities are compared, it is evident that the FCWQF influent had consistently higher concentrations of nutrients, TOC, TSS, herbicides, phthalates, and PAHs than were present at the CSWQF. Recent research suggests that as the influent concentration of a stormwater pollutant increases, the removal efficiency of the treatment train also increases (McNett et al., 2011; Tsuzuki, 2012). Thus, we would expect to find that the FCWQF has higher removal efficiencies if its influent has higher pollutant concentrations. In the same way, it is not surprising that the CSWQF had higher removal efficiencies for total and dissolved metals for the spring storm; it also had much higher concentrations of these pollutants in the influent. However, removal efficiencies did not follow this trend for metals during the fall event or for phthalates during either event. For those pollutants, removal efficiencies were higher at the CSWQF despite it having lower influent concentrations than were present at the FCWQF. Phthalate influent concentrations at the FCWQF were 35 percent higher than at the CSWQF for the fall event and 63 percent higher for the spring event, yet the CSWQF removal efficiency was 60 percent versus 41 and 56 percent at the FCWQF. These differences may not be statistically significant, but they highlight the possibility that the CSWQF treatment train may be more effective at removing these pollutants than its counterpart at the FCWQF. 


\subsection{Differences between the Fall and Spring Events}

Overall, the removal efficiencies for nutrients, TSS, metals, mercury constituents, phthalates, and PAHs were highest at both facilities for the spring event. During the fall event, removal efficiencies were especially low at the CSWQF, which functioned as a source of nutrients, TSS, TOC, and several heavy metals. Nutrient concentrations increased by 46 percent, TSS by 107 percent, TOC by 90 percent, and several metals between 12 and 19 percent. The FCWQF continued to act as a sink for most pollutants during the fall event, yet removal efficiencies were still lower for almost all pollutant groups; the exception was for PAHs, in which removal efficiencies were comparable to the spring event.

Lower removal efficiencies in the fall could be due to a combination of several factors. The fall event was one of the first storms of the season, and the rainfall intensity was much higher over the early portion of the storm than occurred during the spring event. 0.23 inch of rainfall occurred during the first two hours of the fall event versus 0.10 inch over the same amount of time for the spring event. During the fall event, these two factors likely resulted in a resuspension of pollutants that had accumulated and settled in the facilities prior to the storm. Storm intensity and runoff volume influence pollutant retention in stormwater wetlands by affecting the degree of bottom scouring that occurs and the subsequent resuspension of settled particulates. This resuspension impacts the retention of solids and solid-associated pollutants by the facility (Carleton et al., 2000). Seasonal effects may also be partly responsible for the lower removal efficiencies that were estimated for the fall event. Many nutrients, metals, and organic pollutants are either primarily or secondarily removed from the water column through biological processes including bacterial metabolism, plant metabolism, and plant absorption (Vymazal et al., 1998a). These removal mechanisms may have played a more active role in the March event than they did in the November event. Additionally, research shows that the presence of a long antecedent dry period allows pollutants to build up on impervious surfaces, and the first storm of the season may have higher pollutant concentrations than later events (Lee et al., 2004). However, the storm intensity likely played a larger role 
than any anticipated "first flush" effect when considering the high effluent concentrations of the fall event. Almost without exception, the influent concentrations of pollutants were measurably lower during the fall event than the spring event despite the antecedent dry period.

With that said, it cannot be definitively stated that there was an actual difference in pollutant removal efficiencies between the fall and spring events because of the small sample size used $(n=2)$. It is possible that the observed differences between influent and effluent concentrations are due to natural variability and not to the performance of the water quality facilities or their components.

\subsection{Analysis of Low-level Mercury}

During the spring event, mercury samples were collected and analyzed using both standard and ultraclean methods. The goal was to compare the results of relatively inexpensive standard analytical methods to those achieved through ultra-clean sampling techniques and analysis under clean room conditions. If these results could be correlated, then it would be possible to estimate low-level mercury through normal composite sampling rather than expensive low-level analysis. The results shown for THg in the "Mercury - by ICPMS" and "Mercury Constituents - Low-level Analysis" groupings in Tables 23 through 26 are inconclusive as to whether any relationship exists. Neither THg reading was consistently higher or lower than the other. Event-based sampling for THg using these two methods should be continued until enough the dataset is large enough for a regression analysis.

\subsection{Study Limitations}

Due to the small sample size, there are various limitations that must be taken into account when interpreting the results. First, some degree of pretreatment is inherent in all stormwater entering the FCWQF. For example, the City of Gresham employs regular street sweeping as a water quality BMP. Thus, the stormwater entering the facility with the first flush has already been treated to some extent by the partial removal of contaminants. Because of this, the pollutant removal efficiencies that were 
determined in this study are contingent on prior stormwater treatment. As an example, the FCWQF treatment train reduced TSS concentrations by 69 percent or $19.8 \mathrm{mg} / \mathrm{L}$ for the spring event. However, this removal efficiency would change if the influent EMC of TSS changed due to a cessation in street sweeping.

Similarly, the removal efficiencies of each component of the treatment train are dependent on the forms of treatment that occurred previously. At the FCWQF, the calculated pollutant removal efficiency of the WDP is dependent on the mass of pollutants removed in the SFB component. Likewise, the calculated efficiencies for the CSW component are dependent on the removal of pollutants by the prior two treatment train components.

It must be kept in mind that performance of the treatment train components vary with storm intensity and/or duration. With only two storm events being sampled, the results are specific to events with the same characteristics that were present during sampling. These characteristics include, but are not limited to, the antecedent moisture condition, season, and rainfall intensity.

Finally, although this report provides a good estimate of removal efficiencies for the two facilities and their treatment train components, better estimates would be possible with changes in the way that data is collected. The use of automatic samplers could greatly increase the accuracy of EMC estimates. Whereas time-paced, equal volume composites are the only feasible method of sample collection when aliquots are collected as individual grab samples, automatic samplers would allow for the collection of flow- or volume-weighted composite samples. These composite samples would take variations in flow throughout the storm event into account and provide more accurately weighted EMCs. The installation of more accurate and reliable flow meters at the inlets and outlet would also improve the accuracy of pollutant removal efficiencies. Rather than using techniques that weight the pollutant EMCs based on drainage area or visual estimation of flow, these devices could provide an accurate quantification of stormwater volume to be used in the development of weighted influent concentrations as discussed in Section 3.4. 


\subsection{CONCLUSIONS AND RECOMMENDATIONS}

The objectives of this project were to produce an assessment of the performance of the water quality facilities and their components and to use this as a demonstration for the effectiveness of similar BMPs at removing pollutant inputs from municipal stormwater discharges. Both the Columbia Slough and Fairview Creek Water Quality Facilities effectively reduced the event mean concentrations of most pollutants. Pollutant removal efficiencies appear to be affected by external factors such as season and rainfall intensity. Ideally, data collection will continue at both facilities as part of a long-term monitoring program. As additional data is collected for the CSWQF and FCWQF individual treatment train components, it will be possible to statistically analyze differences in influent and effluent concentrations and provide a better estimate of their pollutant removal efficiencies. Until this is done, any differences between the two facilities or among the FCWQF components are speculative.

The results of this report show that treatment trains may be an effective means of reducing pollutant concentrations in stormwater effluent for areas with soils, hydrology, and pollutant issues similar to those present in the City of Gresham. The data quantifying the effectiveness of the treatment trains and their components will aid City staff in making the best decisions about which BMPs should be used at Kelly Creek and in other watersheds to meet current TMDLs and provide treatment for additional pollutants that may be listed in the future.

The following are recommendations for improving future stormwater monitoring and analysis at these facilities:

- Continue long-term data collection at the inlets and outlets of the FCWQF treatment train components. Too few samples have been collected for the pollutant removal efficiencies of the individual components to be statistically demonstrated. 8 to 13 additional samples would allow the City to accurately compare influent and effluent EMCs at a 95\% confidence level 
and with a statistical power of $80 \%$ (Law, Fraley-McNeal, Cappiella, 2008). This would largely minimize the possibility of both Type I and Type II statistical errors.

- Continue long-term data collection at the inlets and outlet of the CSWQF treatment train. Two sampling events have occurred, but similar to the recommendation above, increasing the sample size to a minimum of 10 will aid in the statistical analysis of the facility's pollutant removal effectiveness.

- If additional data on the effectiveness of specific treatment train components at the CSWQF is desired, expand data collection to assist in quantifying pollutant removal efficiencies for the treatment train components. Although this will significantly increase the number of composite samples that will need to be analyzed, composite samples could be collected at both of the facility inlets, at the outlet of the sedimentation forebays, at the bottom of one or more water quality terraces, and at the facility outlet. If overall facility effectiveness is the most important factor to quantify, merely continue data collection at the two inlets and the outlet.

- Many of the treatment train components in this study receive stormwater that has previously been treated by other structural BMPs; if additional data on the effectiveness of components when they function in isolation is desired, identify stand-alone facilities for additional monitoring.

- Improve the calibration of the installed flow monitoring equipment so that more accurate facility influent EMCs may be calculated for all events at the CSWQF and storm events during which stormwater flows are present in the secondary inlet at the FCWQF. Flow data will also allow the estimation of pollutant mass transport and storage.

- Use automatic samplers to collect flow-weighted composite samples in place of time-paced, equal volume composite samples. This will yield a composite sample with more representative EMCs. The time-paced, equal volume compositing method tends to give too 
much weight to pollutant concentrations during periods of low flow and too little weight to pollutant concentrations during periods of high flow. Differences in rainfall intensity throughout a storm event and differences in the movement of pollutants throughout an event (i.e. "first flush" effect) may result in the EMCs being skewed in a variety of ways.

- Discontinue regular collection and analysis of constituents that were not generally present at detectable levels, including DNi, DCd, and VOCs at both facilities, and TCd at the FCWQF.

- Discontinue regular collection and analysis of organochlorine pesticides; the variability in the MRLs due to matrix interferences at the laboratory rendered the data useless for purposes of establishing pollutant removal efficiencies for this study. On the other hand, if the goal is to achieve certain minimum effluent EMCs, the data may be adequate to show whether or not these were met.

- Consider using particle size distribution as a surrogate for heavy metal concentrations. Research suggests that concentrations of total cadmium, copper, lead, and zinc are highly correlated to particles sized from 4 to $6 \mu \mathrm{m}$, with correlations decreasing as particle size increases (Westerlund and Viklander, 2006). Other research has shown that total copper and zinc are primarily associated with fine particulates in the 1 to $10 \mu \mathrm{m}$ range (Muthukrishnan, 2006). Linear regression analysis could be used on existing data that was collected at the Columbia Slough and Fairview Creek Water Quality Facilities to determine the relationship between heavy metals concentrations, TSS, and particle size. Depending on the strength of the relationships, particle size could be used to estimate heavy metals concentrations for stormwater samples. The results from an additional 2 to 7 sampling events would increase the statistical power of the analysis to $\beta=0.2$ when $\alpha=0.05$. This would allow multiple pollutant concentrations to be estimated using a single particle size distribution analysis.

- Research suggests that particle size is also highly correlated with the concentration of phosphorus and PAHs. This opens up the possibility for using particle size as a surrogate for 
phosphorus and PAH concentrations as well. A study by Waschbush et al. (1999) found that particles larger than $250 \mu \mathrm{m}$ in size contributed nearly $50 \%$ of the mass of total phosphorus and leaf material contributed an additional 30\%. Bathi et al. (2012) found that PAH concentrations had a bimodal distribution with concentrations being the highest when associated with particles less than $90 \mu \mathrm{m}$ and greater than $710 \mu \mathrm{m}$ in size. 13 PAHs were sampled at 3 locations, and all but 4 of the PAH-location combinations showed significant differences in PAH concentration by particle size. Similar to the recommendation above, linear regression analysis could be used on existing data to determine total phosphorusparticle size and PAH-particle size relationships. The results from an additional 2 to 7 sampling events for total phosphorus and 8 to 13 sampling events for PAHs would increase the statistical power of the analysis to $\beta=0.2$ when $\alpha=0.05$. Depending on the strength of the relationships, particle size could be used to estimate total phosphorus and $\mathrm{PAH}$ concentrations for stormwater samples.

\subsection{REFERENCES}

Barringer, T.H., Reiser, R. G., Price, C. V., 1994. Potential effects of development on flow characteristics of two New Jersey streams. Journal of the American Water Resources Association 30, 283-295.

Bathi, J.R., Pitt, R.E., Clark, S.E., 2012. Polycylcic aromatic hydrocarbons in urban stream sediments. Advances in Civil Engineering, Article ID 372395.

Carleton, J.N., Grizzard, T.J., Godrej, A.N., Post, H.E., Lampe, L., Kenel, P.P., 2000. Performance of a constructed wetlands in treating urban stormwater runoff. Water Environment Research 72(3), 295-304.

Carlisle, T.J., \& Mulamoottil, G., 1991. Artificial wetlands for the treatment of stormwater. Canadian Water Resources Journal 16(4), 331-343.

Clary, J., Leisenring, M., Hobson, P., 2011. International Stormwater Best Management Practices (BMP) Database Pollutant Category Summary: Metals. International Stormwater BMP Database.

Clary, J., Leisenring, M., \& Jeray, J., 2010. International Stormwater Best Management Practices (BMP) Database Pollutant Category Summary: Fecal Indicator Bacteria. International Stormwater BMP Database. 
Diblasi, C.J., Li, H., Davis, A.P., Ghosh, U., 2009. Removal and fate of polycyclic aromatic hydrocarbon pollutants in an urban stormwater bioretention facility. Environmental Science and Technology 43, 494-502.

GeoSyntec Consultants, Urban Water Resources Research Council of ASCE, 2002. Urban Stormwater BMP Performance Monitoring. Washington, DC: US Environmental Protection Agency.

Hood, M.J., Clausen, J.C., Warner, G.S., 2007. Comparison of stormwater lag times for low impact and traditional residential development. Journal of the American Water Resources Association 43(4), 1036-1046.

Karickhoff, S.W., Brown, D.S., Scott, T.A., 1978. Sorption of hydrophobic pollutants on natural sediments. Water Research 13, 241-248.

Korstrom, J.S., Birtwell, I.K., 2006. Effects of suspended sediment on the escape behavior and coverseeking response of juvenile Chinook salmon in freshwater. Transactions of the American Fisheries Society 134(4), 1006-1016.

Law, N.L., Fraley-McNeal, L., Cappiella, K., 2008. Monitoring to demonstrate environmental results: guidance to develop local stormwater monitoring studies using six example study designs. Ellicott City, MD: Center for Watershed Protection.

Lee, H., Lau, S.L., Kayhanian, M., Stenstrom, M.K., 2004. Seasonal first flush phenomenon of urban stormwater discharges. Water Research 38(19), 4153-4163.

Leisenring, M., Clary, J., Lawler, K., Hobson, P., 2011. International Stormwater Best Management Practices (BMP) Database Pollutant Category Summary: Solids (TSS, TDS, and Turbidity). International Stormwater BMP Database.

Leisenring, M., Clary, J., Stephenson, J., Hobson, P., 2010. International Stormwater Best Management Practices (BMP) Database Pollutant Category Summary: Nutrients. International Stormwater BMP Database.

Maine, M.A., Sune, N., Hadad, H., Sanchez, G., Bonetto, C., 2006. Nutrient and metal removal in a constructed wetland for wastewater treatment from a metallurgic industry. Ecological Engineering 26, 341-347.

McMahon, G., Cuffney, T.F., 2000. Quantifying urban intensity in drainage basins for assessing stream ecological conditions. Journal of the American Water Resources Association 36, 1247-1262.

McNett, J.K., Hunt, W.F., Davis, A.P., 2011. Influent pollutant concentrations as predictors of effluent pollutant concentrations for mid-Atlantic bioretention. Journal of Environmental Engineering 137, 790-799.

Muthukrishnan, S., 2006. Treatment of heavy metals in stormwater runoff using wet pond and wetland mesocosms. Proceedings of the Annual International Conference on Soils, Sediments, Water, and Energy 11(9). 
Paul, M.J., Meyer, J.L., 2001. Streams in the urban environment. Annual Review of Ecology and Systematics 32, 333-365.

Schulz, R., Peall, S.K., 2001. Effectiveness of a constructed wetland for retention of nonpoint-source pesticide pollution in the Lourens River Catchment, South Africa. Environmental Science and Technology 35(2), 422-426.

Singh, A., Armbya, N., Singh, A.K., 2010. ProUCL Version 4.1.00 Technical Guide (Draft): Statistical software for environmental applications for data sets with and without nondetect observations. Washington, DC: US Environmental Protection Agency.

Tsuzuki, Y., 2012. Linking sanitation and wastewater treatment: from evaluation on the basis of effluent pollutant concentrations to evaluation on the basis of pollutant removal efficiencies. Water Science and Technology 65(2), 368-379.

Vymazal, J., Brix, H., Cooper, P.F., Haberl, R., Perfler, R., Laber, J., 1998. Removal mechanisms and types of constructed wetlands. In J. Vymazal, H. Brix, P. Cooper, M.B. Green, R. Haberl, Constructed Wetlands for Wastewater Treatment in Europe (pp. 17-66). Leiden, The Netherlands: Backhuys Publisher.

Wadzuk, B.M., Rea, M., Woodruff, G., Flynn, K., Traver, R.G., 2010. Water-quality performance of a constructed stormwater wetland for all flow conditions. Journal of the American Water Resources Association 46(2), 385-394.

Wang, L., Lyons, J., 2003. Fish and benthic macroinvertebrate assemblages as indicators of stream degradation in urbanizing watersheds. In T. Simon (Ed.), Biological Response Signatures: Indicator Patterns Using Aquatic Communities (pp. 227-250). Boca Raton, FL: CRC Press.

Waser, W., Bausheva, O., Nikinmaa, M., 2009. The copper-induced reduction of critical swimming speed in rainbow trout (Oncorhynchus mykiss) is not caused by changes in gill structure. Aquatic Toxicology 94(1), 77-79.

Waschbusch, R.J., Selbig, W.R., Bannerman, R.T., 1999. Sources of phosphorus in stormwater and street dirt from two urban residential basins in Madison, Wisconsin, 1994-95. Water-Resources Investigations Report 99-4021, Washington, D.C.: U.S. Geological Survey.

Watershed Management Division, 2011. Stormwater Management Plan. Gresham, OR: Department of Environmental Services.

Westerlund, C., Viklander, M., 2006. Particles and associated metals in road runoff during snowmelt and rainfall. Science of the Total Environment 362(1-3): 143-156.

Wood, P.J., Armitage, P.D., 1997. Biological effects of fine sediment in the lotic environment. Environmental Management 21(2), 203-217.

Yeh, T.Y., 2008. Removal of metals in construccted wetlands: review. Practice Periodical of Hazardous, Toxic, and Radioactive Waste Management 12(2), 96-101. 


\section{APPENDIX A - Complete List of Contaminants}

Bacteria

- E. coli

Chlorinated Herbicides

- Acifluofen

- Bentazon

- 2,4-D

- 2,4-DB

- Dicamba

- 3,5-Dichlorobenzoic acid

- Dichlorprop

- Dinoseb

- Pentachlorophenol

- Picloram

- 2,4,5-T

- 2,4,5-TP

Field Parameters

- Conductivity

- Dissolved Oxygen

- $\mathrm{pH}$

- Temperature

- Turbidity

General Chemistry

- Five-day Biological Oxygen Demand

- Total Hardness as $\mathrm{CaCO}_{3}$

- Total Organic Carbon

- Total Suspended Solids

Metals (Dissolved and Total)

- Antimony

- Arsenic

- Cadmium

- Copper

- Lead

- Mercury

- Methylmercury

- Nickel

- Zinc

Nutrients

- Ammonia-Nitrogen

- Nitrate-Nitrogen

- Orthophosphate
- Total Kjeldahl Nitrogen

- Total Phosphorus

Organochlorine Pesticides

- Aldrin

- alpha-BHC

- beta-BHC

- delta-BHC

- gamma-BHC

- gamma-chlordane

- 4,4'-DDD

- $4,4^{\prime}-\mathrm{DDE}$

- 4,4'-DDT

- Dieldrin

- Endrin

- Endrin aldehyde

- Endrin keytone

- Endosulfan I

- Endosulfan II

- Endosulfan sulfate

- Heptachlor

- Heptachlor epoxide

- Methoxychlor

- Toxaphene

Phthalates

- Butyl benzyl phthalate

- Di-n-butyl phthalate

- Diethyl phthalate

- Dimethyl phthalate

- Di-n-octyl phthalate

- bis(2-ethylhexyl) phthalate

Polynuclear Aromatic Hydrocarbons

- Acenaphthene

- Acenaphthylene

- Anthracene

- Benzo(a)anthracene

- Benzo(a)pyrene

- Benzo(b)fluoranthene

- $\operatorname{Benzo}(\mathrm{g}, \mathrm{h}, \mathrm{i})$ perylene

- Benzo(k)fluoranthene

- Chrysene 
- Dibenzo(a,h)anthracene

- Fluoranthene

- Fluorine

- Ideno(1,2,3-cd)pyrene

- Naphthalene

- Phenanthrene

- Pyrene

Volatile Organic Compounds

- Acetone

- Benzene

- Bromobenzene

- Bromochloromethane

- Bromodichloromethane

- Bromoform

- Bromomethane

- 2-Butanone

- n-Butylbenzene

- sec-Butylbenzene

- tert-Butylbenzene

- Carbon disulfide

- Carbon tetrachloride

- Chlorobenzene

- Chloroethane

- Chloroform

- Chloromethane

- 2-Chlorotoluene

- 4-Chlorotoluene

- 1,2-Dibromo-3-chloropropane

- Dibromochloromethane

- 1,2-Dibromoethane

- Dibromomethane

- 1,2-Dichlorobenzene

- 1,3-Dichlorobenzene

- 1,4-Dichlorobenzene

- Dichlorodifluoromethane

- 1,1-Dichloroethane

- 1,2-Dichloroethane
- 1,1-Dichloroethene

- cis-1,2-Dichloroethene

- trans-1,2-Dichloroethene

- 1,2-Dichloropropane

- 1,3-Dichloropropane

- 2,2-Dichloropropane

- 1,1-Dichloropropene

- cis-1,3-Dichloropropene

- trans-1,3-Dichloropropene

- Ethylbenzene

- Hexachlorobutadiene

- 2-Hexanone

- Isopropylbenzene

- 4-Isopropyltoluene

- 4-Methyl-2-pentanone

- Methylene chloride

- Naphthalene

- n-Propylbenzene

- Styrene

- 1,1,1,2-Tetrachloroethane

- 1,1,2,2-Tetrachloroethane

- Tetrachloroethene

- Toluene

- 1,2,3-Trichlorobenzene

- 1,2,4-Trichlorobenzene

- 1,1,1-Trichloroethane

- 1,1,2-Trichloroethane

- Trichloroethene

- Trichlorofluoromethane

- 1,2,3-Trichloropropane

- 1,2,4-Trimethylbenzene

- 1,3,5-Trimethylbenzene

- Vinyl acetate

- Vinyl chloride

- m,p-Xylene

- o-Xylene 


\section{APPENDIX B - Raw Influent and Effluent Event Mean Concentrations for the FCWQF CSW Component and the Entire Treatment Train}

Table 39. Raw nutrient EMCs at the CSW component and the entire FCWQF treatment train for the fall event

\begin{tabular}{|c|c|c|c|c|c|c|c|}
\hline \multicolumn{8}{|c|}{ 11/2/2011 Sampling Event } \\
\hline \multirow{3}{*}{ Analyte } & \multirow{3}{*}{ Unit } & \multicolumn{3}{|c|}{ CSW } & \multicolumn{3}{|c|}{ Entire Facility } \\
\hline & & \multicolumn{2}{|c|}{ Inlets } & Outlet & \multicolumn{2}{|c|}{ Inlets } & Outlet \\
\hline & & 3 & 5 & 4 & 1 & 5 & 4 \\
\hline \multicolumn{8}{|l|}{ Nutrients } \\
\hline Total Nutrients & $\mathrm{mg} / \mathrm{L}$ & 0.68 & 0.85 & 0.67 & 0.84 & 0.85 & 0.67 \\
\hline Ammonia- $\mathrm{N}\left(\mathrm{NH}_{3}-\mathrm{N}\right)$ & $\mathrm{mg} / \mathrm{L}$ & $<0.020$ & 0.096 & $<0.020$ & 0.075 & 0.096 & $<0.020$ \\
\hline Nitrate- $\mathrm{N}\left(\mathrm{NO}_{3}-\mathrm{N}\right)$ & $\mathrm{mg} / \mathrm{L}$ & $<0.10$ & $<0.10$ & $<0.10$ & $<0.10$ & $<0.10$ & $<0.10$ \\
\hline Total Kjeldahl N (TKN) & $\mathrm{mg} / \mathrm{L}$ & 0.44 & 0.51 & 0.43 & 0.52 & 0.51 & 0.43 \\
\hline Orthophosphate (OP) & $\mathrm{mg} / \mathrm{L}$ & 0.030 & 0.041 & 0.030 & 0.040 & 0.041 & 0.030 \\
\hline Total Phosphorus (TP) & $\mathrm{mg} / \mathrm{L}$ & 0.0880 & 0.100 & 0.0880 & 0.105 & 0.100 & 0.0880 \\
\hline
\end{tabular}

Table 40. Nutrient EMCs at the CSW component and the entire FCWQF treatment train for the spring event

\begin{tabular}{|c|c|c|c|c|c|c|c|}
\hline \multicolumn{8}{|c|}{ 3/15/2012 Sampling Event } \\
\hline \multirow{3}{*}{ Analyte } & \multirow{3}{*}{ Unit } & \multicolumn{3}{|c|}{ CSW } & \multicolumn{3}{|c|}{ Entire Facility } \\
\hline & & \multicolumn{2}{|c|}{ Inlets } & \multirow{2}{*}{$\frac{\text { Outlet }}{4}$} & \multicolumn{2}{|c|}{ Inlets } & \multirow{2}{*}{$\frac{\text { Outlet }}{4}$} \\
\hline & & 3 & 5 & & 1 & 5 & \\
\hline \multicolumn{8}{|l|}{ Nutrients } \\
\hline Total Nutrients & $\mathrm{mg} / \mathrm{L}$ & 0.97 & 0.97 & 0.84 & 1.3 & 0.87 & 0.84 \\
\hline Ammonia-N $\left(\mathrm{NH}_{3}-\mathrm{N}\right)$ & $\mathrm{mg} / \mathrm{L}$ & 0.12 & 0.072 & 0.096 & 0.11 & 0.072 & 0.096 \\
\hline Nitrate-N $\left(\mathrm{NO}_{3}-\mathrm{N}\right)$ & $\mathrm{mg} / \mathrm{L}$ & 0.28 & $<0.10$ & 0.22 & 0.43 & $<0.10$ & 0.22 \\
\hline Total Kjeldahl N (TKN) & $\mathrm{mg} / \mathrm{L}$ & 0.47 & 0.66 & 0.44 & 0.65 & 0.66 & 0.44 \\
\hline Orthophosphate (OP) & $\mathrm{mg} / \mathrm{L}$ & $<0.020$ & $<0.020$ & $<0.020$ & $<0.020$ & $<0.020$ & $<0.020$ \\
\hline Total Phosphorus (TP) & $\mathrm{mg} / \mathrm{L}$ & 0.0720 & 0.118 & 0.0650 & 0.0950 & 0.118 & 0.0650 \\
\hline
\end{tabular}

Table 41. Raw general chemistry EMCs at the CSW component and the entire FCWQF treatment train for the fall event

\begin{tabular}{|c|c|c|c|c|c|c|c|}
\hline \multicolumn{8}{|c|}{ 11/2/2011 Sampling Event } \\
\hline \multirow{3}{*}{ Analyte } & \multirow{3}{*}{ Unit } & \multicolumn{3}{|c|}{ CSW } & \multicolumn{3}{|c|}{ Entire Facility } \\
\hline & & \multicolumn{2}{|c|}{ Inlets } & Outlet & \multicolumn{2}{|c|}{ Inlets } & Outlet \\
\hline & & 3 & 5 & 4 & 1 & 5 & 4 \\
\hline \multicolumn{8}{|l|}{ General Chemistry } \\
\hline $\mathrm{BOD}_{5}$ & $\mathrm{mg} / \mathrm{L}$ & 4 & 6 & 3 & 7 & 6 & 3 \\
\hline Total Organic Carbon (TOC) & $\mathrm{mg} / \mathrm{L}$ & 2.86 & 3.10 & 3.12 & 2.46 & 3.10 & 3.12 \\
\hline Total Suspended Solids (TSS) & $\mathrm{mg} / \mathrm{L}$ & 6 & 28 & 6 & 11 & 28 & 6 \\
\hline
\end{tabular}


Table 42. Raw general chemistry EMCs at the CSW component and the entire FCWQF treatment train for the spring event

\begin{tabular}{|c|c|c|c|c|c|c|c|}
\hline \multicolumn{8}{|c|}{ 3/15/2012 Sampling Event } \\
\hline \multirow{3}{*}{ Analyte } & \multirow{3}{*}{ Unit } & \multicolumn{3}{|c|}{ CSW } & \multicolumn{3}{|c|}{ Entire Facility } \\
\hline & & \multicolumn{2}{|c|}{ Inlets } & Outlet & \multicolumn{2}{|c|}{ Inlets } & Outlet \\
\hline & & 3 & 5 & 4 & 1 & 5 & 4 \\
\hline \multicolumn{8}{|l|}{ General Chemistry } \\
\hline $\mathrm{BOD}_{5}$ & $\mathrm{mg} / \mathrm{L}$ & 3 & 3 & 2 & 6 & 3 & 2 \\
\hline Total Organic Carbon (TOC) & $\mathrm{mg} / \mathrm{L}$ & 3.56 & 2.33 & 3.24 & 5.79 & 2.33 & 3.24 \\
\hline Total Suspended Solids (TSS) & $\mathrm{mg} / \mathrm{L}$ & 7 & 36 & 9 & 28 & 36 & 9 \\
\hline
\end{tabular}

Table 43. Raw metals EMCs at the CSW component and the entire FCWQF treatment train for the fall event

\begin{tabular}{|c|c|c|c|c|c|c|c|}
\hline \multicolumn{8}{|c|}{ 11/2/2011 Sampling Event } \\
\hline \multirow{3}{*}{ Analyte } & \multirow{3}{*}{ Unit } & \multicolumn{3}{|c|}{ CSW } & \multicolumn{3}{|c|}{ Entire Facility } \\
\hline & & \multicolumn{2}{|c|}{ Inlets } & Outlet & \multicolumn{2}{|c|}{ Inlets } & Outlet \\
\hline & & 3 & 5 & 4 & 1 & 5 & 4 \\
\hline \multicolumn{8}{|l|}{ Metals, Dissolved } \\
\hline Total Dissolved Metals & $\mu \mathrm{g} / \mathrm{L}$ & 33.3 & 28.7 & 35.2 & 29.7 & 28.7 & 35.1 \\
\hline Copper (DCu) & $\mu \mathrm{g} / \mathrm{L}$ & 2.49 & 2.24 & 2.35 & 2.37 & 2.24 & 2.35 \\
\hline Lead (DPb) & $\mu \mathrm{g} / \mathrm{L}$ & $<0.100$ & 0.133 & $<0.100$ & 0.140 & 0.133 & $<0.100$ \\
\hline Nickel (DNi) & $\mu \mathrm{g} / \mathrm{L}$ & $<0.500$ & $<0.500$ & $<0.500$ & $<0.500$ & $<0.500$ & $<0.500$ \\
\hline Zinc (DZn) & $\mu \mathrm{g} / \mathrm{L}$ & 30.2 & 25.8 & 32.2 & 26.7 & 25.8 & 32.2 \\
\hline \multicolumn{8}{|l|}{ Metals, Total } \\
\hline Total Metals & $\mu \mathrm{g} / \mathrm{L}$ & 40.9 & 55.1 & 41.9 & 49.4 & 55.1 & 41.9 \\
\hline Antimony (TSb) & $\mu \mathrm{g} / \mathrm{L}$ & 0.287 & 0.407 & 0.300 & 0.375 & 0.407 & 0.300 \\
\hline Arsenic (TAs) & $\mu \mathrm{g} / \mathrm{L}$ & 0.365 & 0.421 & 0.345 & 0.377 & 0.421 & 0.345 \\
\hline Cadmium (TCd) & $\mu \mathrm{g} / \mathrm{L}$ & $<0.100$ & $<0.100$ & $<0.100$ & $<0.100$ & $<0.100$ & $<0.100$ \\
\hline Copper (TCu) & $\mu \mathrm{g} / \mathrm{L}$ & 3.48 & 5.20 & 3.40 & 4.65 & 5.20 & 3.40 \\
\hline Lead (TPb) & $\mu \mathrm{g} / \mathrm{L}$ & 0.476 & 1.90 & 0.647 & 1.38 & 1.90 & 0.647 \\
\hline Mercury (THg) & $\mathrm{ng} / \mathrm{L}$ & -- & -- & -- & -- & -- & -- \\
\hline Nickel (TNi) & $\mu \mathrm{g} / \mathrm{L}$ & 0.500 & 0.855 & 0.579 & 0.724 & 0.855 & 0.579 \\
\hline Zinc (TZn) & $\mu \mathrm{g} / \mathrm{L}$ & 35.7 & 46.2 & 36.5 & 41.8 & 46.2 & 36.5 \\
\hline \multicolumn{8}{|l|}{ Mercury Constituents - Low-level Analysis } \\
\hline Dissolved Mercury (DHg) & $\mathrm{ng} / \mathrm{L}$ & 1.71 & -- & 2.74 & 2.51 & -- & 2.74 \\
\hline Total Mercury (THg) & $\mathrm{ng} / \mathrm{L}$ & 2.88 & -- & 3.39 & 4.24 & -- & 3.39 \\
\hline Dissolved Methylmercury (DMeHg) & $\mathrm{ng} / \mathrm{L}$ & $<0.050$ & -- & $<0.050$ & $<0.050$ & -- & $<0.050$ \\
\hline Total Methylmercury (TMeHg) & $\mathrm{ng} / \mathrm{L}$ & 0.072 & -- & 0.079 & 0.11 & -- & 0.079 \\
\hline
\end{tabular}


Table 44. Raw metals EMCs at the CSW component and the entire FCWQF treatment train for the spring event

\begin{tabular}{|c|c|c|c|c|c|c|c|}
\hline \multicolumn{8}{|c|}{ 3/15/2012 Sampling Event } \\
\hline \multirow{3}{*}{ Analyte } & \multirow{3}{*}{ Unit } & \multicolumn{3}{|c|}{ CSW } & \multicolumn{3}{|c|}{ Entire Facility } \\
\hline & & \multicolumn{2}{|c|}{ Inlets } & Outlet & \multicolumn{2}{|c|}{ Inlets } & \multirow{2}{*}{$\frac{\text { Outlet }}{4}$} \\
\hline & & 3 & 5 & 4 & 1 & 5 & \\
\hline \multicolumn{8}{|l|}{ Metals, Dissolved } \\
\hline Total Dissolved Metals & $\mu \mathrm{g} / \mathrm{L}$ & 30.2 & 26.1 & 30.6 & 41.4 & 26.1 & 30.6 \\
\hline Antimony (DSb) & $\mu \mathrm{g} / \mathrm{L}$ & 0.219 & 0.184 & 0.210 & 0.329 & 0.184 & 0.210 \\
\hline Arsenic (DAs) & $\mu \mathrm{g} / \mathrm{L}$ & 0.198 & 0.232 & 0.191 & 0.234 & 0.232 & 0.191 \\
\hline Cadmium (DCd) & $\mu \mathrm{g} / \mathrm{L}$ & $<0.100$ & $<0.100$ & $<0.100$ & $<0.100$ & $<0.100$ & $<0.100$ \\
\hline Copper (DCu) & $\mu \mathrm{g} / \mathrm{L}$ & 1.89 & 2.21 & 1.72 & 3.10 & 2.21 & 1.72 \\
\hline Lead (DPb) & $\mu \mathrm{g} / \mathrm{L}$ & $<0.100$ & $<0.100$ & $<0.100$ & 0.112 & $<0.100$ & $<0.100$ \\
\hline Nickel (DNi) & $\mu \mathrm{g} / \mathrm{L}$ & $<0.500$ & $<0.500$ & $<0.500$ & $<0.500$ & $<0.500$ & $<0.500$ \\
\hline Zinc (DZn) & $\mu \mathrm{g} / \mathrm{L}$ & 27.2 & 22.8 & 27.8 & 37.0 & 22.8 & 27.8 \\
\hline \multicolumn{8}{|l|}{ Metals, Total } \\
\hline Total Metals & $\mu \mathrm{g} / \mathrm{L}$ & 41.8 & 62.7 & 43.6 & 78.7 & 62.7 & 43.6 \\
\hline Antimony (TSb) & $\mu \mathrm{g} / \mathrm{L}$ & 0.312 & 0.487 & 0.331 & 0.614 & 0.487 & 0.331 \\
\hline Arsenic (TAs) & $\mu \mathrm{g} / \mathrm{L}$ & 0.291 & 0.437 & 0.292 & 0.421 & 0.437 & 0.292 \\
\hline Cadmium (TCd) & $\mu \mathrm{g} / \mathrm{L}$ & $<0.100$ & $<0.100$ & $<0.100$ & $<0.100$ & $<0.100$ & $<0.100$ \\
\hline Copper (TCu) & $\mu \mathrm{g} / \mathrm{L}$ & 3.13 & 5.79 & 3.17 & 7.27 & 5.79 & 3.17 \\
\hline Lead (TPb) & $\mu \mathrm{g} / \mathrm{L}$ & 0.901 & 3.32 & 1.21 & 2.61 & 3.32 & 1.21 \\
\hline Mercury (THg) & $\mathrm{ng} / \mathrm{L}$ & 3.29 & -- & 2.23 & 7.68 & -- & 2.23 \\
\hline Nickel (TNi) & $\mu \mathrm{g} / \mathrm{L}$ & 0.599 & 1.15 & 0.665 & 1.21 & 1.15 & 0.665 \\
\hline Zinc (TZn) & $\mu \mathrm{g} / \mathrm{L}$ & 36.5 & 51.4 & 37.8 & 66.5 & 51.4 & 37.8 \\
\hline \multicolumn{8}{|l|}{ Mercury Constituents - Low-level Analysis } \\
\hline Dissolved Mercury (DHg) & $\mathrm{ng} / \mathrm{L}$ & 1.8 & -- & 0.78 & 2.6 & -- & 0.78 \\
\hline Total Mercury (THg) & $\mathrm{ng} / \mathrm{L}$ & 3.6 & -- & 3.4 & 5.2 & -- & 3.4 \\
\hline Dissolved Methylmercury (DMeHg) & $\mathrm{ng} / \mathrm{L}$ & 0.12 & -- & 0.061 & 0.11 & -- & 0.061 \\
\hline Total Methylmercury (TMeHg) & $\mathrm{ng} / \mathrm{L}$ & 0.27 & -- & 0.14 & 0.24 & -- & 0.14 \\
\hline
\end{tabular}


Table 45. Raw organics EMCs at the CSW component and the entire FCWQF treatment train for the fall event

\begin{tabular}{|c|c|c|c|c|c|c|c|}
\hline \multicolumn{8}{|c|}{ 11/2/2011 Sampling Event } \\
\hline \multirow{3}{*}{ Analyte } & \multirow{3}{*}{ Unit } & \multicolumn{3}{|c|}{ CSW } & \multicolumn{3}{|c|}{ Entire Facility } \\
\hline & & \multicolumn{2}{|c|}{ Inlets } & \multirow{2}{*}{$\begin{array}{c}\text { Outlet } \\
4\end{array}$} & \multicolumn{2}{|c|}{ Inlets } & \multirow{2}{*}{$\begin{array}{c}\text { Outlet } \\
4\end{array}$} \\
\hline & & 3 & 5 & & 1 & 5 & \\
\hline \multicolumn{8}{|l|}{ Chlorinated Herbicides } \\
\hline 2,4-D (Chlorophenoxy Herbicide) & $\mu \mathrm{g} / \mathrm{L}$ & 0.527 & 0.227 & 0.420 & 0.305 & 0.227 & 0.420 \\
\hline Pentachlorophenol & $\mu \mathrm{g} / \mathrm{L}$ & 0.0900 & 0.119 & 0.0852 & 0.113 & 0.119 & 0.0852 \\
\hline Other Herbicides & $\mu \mathrm{g} / \mathrm{L}$ & ND & ND & ND & ND & ND & ND \\
\hline \multicolumn{8}{|l|}{ Organochlorine Pesticides } \\
\hline BHC, alpha- & $\mathrm{ng} / \mathrm{L}$ & $<1.2$ & $<1.3$ & $<0.70$ & 0.66 & $<1.3$ & $<0.70$ \\
\hline Other Pesticides & $\mathrm{ng} / \mathrm{L}$ & ND & ND & ND & ND & ND & ND \\
\hline \multicolumn{8}{|l|}{ Phthalates } \\
\hline Bis(2ethylhexyl)phthalate & $\mu \mathrm{g} / \mathrm{L}$ & 1.0 & 1.3 & $<1.0$ & 1.8 & 1.3 & $<1.0$ \\
\hline Other Phthalates & $\mu \mathrm{g} / \mathrm{L}$ & ND & ND & ND & ND & ND & ND \\
\hline \multicolumn{8}{|c|}{ Polynuclear Aromatic Hydrocarbons (PAHs) } \\
\hline Total PAHs & $\mu \mathrm{g} / \mathrm{L}$ & 0.029 & 0.25 & 0.16 & 0.41 & 0.25 & 0.16 \\
\hline Benzo(a)anthracene & $\mu \mathrm{g} / \mathrm{L}$ & $<0.010$ & $<0.010$ & $<0.010$ & 0.015 & $<0.010$ & $<0.010$ \\
\hline Benzo(a)pyrene & $\mu \mathrm{g} / \mathrm{L}$ & $<0.010$ & $<0.010$ & $<0.010$ & 0.023 & $<0.010$ & $<0.010$ \\
\hline Benzo(b)fluoranthene & $\mu \mathrm{g} / \mathrm{L}$ & $<0.010$ & 0.017 & $<0.010$ & 0.038 & 0.017 & $<0.010$ \\
\hline Benzo(ghi)perylene & $\mu \mathrm{g} / \mathrm{L}$ & $<0.010$ & 0.033 & $<0.010$ & 0.043 & 0.033 & $<0.010$ \\
\hline Benzo(k)fluoranthene & $\mu \mathrm{g} / \mathrm{L}$ & $<0.010$ & $<0.010$ & $<0.010$ & 0.013 & $<0.010$ & $<0.010$ \\
\hline Chrysene & $\mu \mathrm{g} / \mathrm{L}$ & $<0.010$ & 0.018 & $<0.010$ & 0.031 & 0.018 & $<0.010$ \\
\hline Fluoranthene & $\mu \mathrm{g} / \mathrm{L}$ & 0.012 & 0.039 & 0.012 & 0.072 & 0.039 & 0.012 \\
\hline Indeno(1,2,3-cd)pyrene & $\mu \mathrm{g} / \mathrm{L}$ & $<0.010$ & 0.010 & $<0.010$ & 0.021 & 0.010 & $<0.010$ \\
\hline Naphthalene & $\mu \mathrm{g} / \mathrm{L}$ & $<0.040$ & 0.049 & $<0.040$ & 0.041 & 0.049 & $<0.040$ \\
\hline Phenanthrene & $\mu g / L$ & $<0.020$ & 0.041 & $<0.020$ & 0.052 & 0.041 & $<0.020$ \\
\hline Pyrene & $\mu \mathrm{g} / \mathrm{L}$ & 0.017 & 0.045 & 0.017 & 0.063 & 0.045 & 0.017 \\
\hline Other PAHs & $\mu \mathrm{g} / \mathrm{L}$ & ND & ND & ND & ND & ND & ND \\
\hline \multicolumn{8}{|l|}{ Volatile Organic Compounds (VOCs) } \\
\hline Other VOCs & $\mathrm{ng} / \mathrm{L}$ & ND & ND & ND & ND & ND & ND \\
\hline
\end{tabular}


Table 46. Raw organics EMCs at the CSW component and the entire FCWQF treatment train for the spring event

\begin{tabular}{|c|c|c|c|c|c|c|c|}
\hline \multicolumn{8}{|c|}{ 3/15/2012 Sampling Event } \\
\hline \multirow{3}{*}{ Analyte } & \multirow{3}{*}{ Unit } & \multicolumn{3}{|c|}{ CSW } & \multicolumn{3}{|c|}{ Entire Facility } \\
\hline & & \multicolumn{2}{|c|}{ Inlets } & Outlet & \multicolumn{2}{|c|}{ Inlets } & Outlet \\
\hline & & 3 & 5 & 4 & 1 & 5 & 4 \\
\hline \multicolumn{8}{|l|}{ Chlorinated Herbicides } \\
\hline 2,4-D (Chlorophenoxy Herbicide) & $\mu \mathrm{g} / \mathrm{L}$ & $<0.100$ & $<0.100$ & $<0.100$ & 0.150 & $<0.100$ & $<0.100$ \\
\hline Pentachlorophenol & $\mu \mathrm{g} / \mathrm{L}$ & 0.0950 & $<0.0400$ & 0.130 & 0.210 & $<0.0400$ & 0.130 \\
\hline Other Herbicides & $\mu \mathrm{g} / \mathrm{L}$ & ND & ND & ND & ND & ND & ND \\
\hline \multicolumn{8}{|l|}{ Organochlorine Pesticides } \\
\hline BHC, gamma- & $\mathrm{ng} / \mathrm{L}$ & $<1.1$ & -- & $<0.70$ & 1.6 & -- & $<0.70$ \\
\hline Endrin aldehyde & $\mathrm{ng} / \mathrm{L}$ & 1.6 & -- & 2.2 & $<2.3$ & -- & 2.2 \\
\hline Other Pesticides & $\mathrm{ng} / \mathrm{L}$ & ND & ND & ND & ND & ND & ND \\
\hline \multicolumn{8}{|l|}{ Phthalates } \\
\hline Bis(2ethylhexyl)phthalate & $\mu \mathrm{g} / \mathrm{L}$ & $<1.0$ & 2.8 & 1.0 & 2.2 & 2.8 & 1.0 \\
\hline Other Phthalates & $\mu \mathrm{g} / \mathrm{L}$ & ND & ND & ND & ND & ND & ND \\
\hline \multicolumn{8}{|c|}{ Polynuclear Aromatic Hydrocarbons (PAHs) } \\
\hline Total PAHs & $\mu \mathrm{g} / \mathrm{L}$ & 0.22 & 1.1 & 0.28 & 0.51 & 1.1 & 0.28 \\
\hline Benzo(a)anthracene & $\mu \mathrm{g} / \mathrm{L}$ & $<0.010$ & 0.039 & $<0.010$ & 0.018 & 0.039 & $<0.010$ \\
\hline Benzo(a)pyrene & $\mu \mathrm{g} / \mathrm{L}$ & $<0.010$ & 0.057 & 0.012 & 0.019 & 0.057 & 0.012 \\
\hline Benzo(b)fluoranthene & $\mu \mathrm{g} / \mathrm{L}$ & $<0.010$ & 0.11 & 0.018 & 0.031 & 0.11 & 0.018 \\
\hline Benzo(ghi)perylene & $\mu \mathrm{g} / \mathrm{L}$ & 0.017 & 0.12 & 0.026 & 0.057 & 0.12 & 0.026 \\
\hline Benzo(k)fluoranthene & $\mu \mathrm{g} / \mathrm{L}$ & $<0.010$ & 0.030 & $<0.010$ & $<0.010$ & 0.030 & $<0.010$ \\
\hline Chrysene & $\mu \mathrm{g} / \mathrm{L}$ & $<0.010$ & 0.085 & 0.015 & 0.031 & 0.085 & 0.015 \\
\hline Dibenzo(a,h)anthracene & $\mu \mathrm{g} / \mathrm{L}$ & $<0.010$ & 0.017 & $<0.010$ & $<0.010$ & 0.017 & $<0.010$ \\
\hline Fluoranthene & $\mu \mathrm{g} / \mathrm{L}$ & 0.024 & 0.19 & 0.037 & 0.086 & 0.19 & 0.037 \\
\hline Fluorene & $\mu \mathrm{g} / \mathrm{L}$ & $<0.020$ & 0.021 & $<0.020$ & 0.021 & 0.021 & $<0.020$ \\
\hline Indeno(1,2,3-cd)pyrene & $\mu \mathrm{g} / \mathrm{L}$ & $<0.010$ & 0.059 & 0.012 & 0.019 & 0.059 & 0.012 \\
\hline Naphthalene & $\mu \mathrm{g} / \mathrm{L}$ & $<0.040$ & 0.049 & $<0.040$ & 0.04 & 0.049 & $<0.040$ \\
\hline Phenanthrene & $\mu \mathrm{g} / \mathrm{L}$ & 0.024 & 0.098 & 0.027 & 0.057 & 0.098 & 0.027 \\
\hline Pyrene & $\mu \mathrm{g} / \mathrm{L}$ & 0.030 & 0.19 & 0.045 & 0.11 & 0.19 & 0.045 \\
\hline Other PAHs & $\mu \mathrm{g} / \mathrm{L}$ & ND & ND & ND & ND & ND & ND \\
\hline \multicolumn{8}{|l|}{ Volatile Organic Compounds (VOCs) } \\
\hline Chloroform & $\mathrm{ng} / \mathrm{L}$ & 4.08 & -- & 2.52 & $<1.00$ & -- & 2.52 \\
\hline Other VOCs & $\mathrm{ng} / \mathrm{L}$ & ND & ND & ND & ND & ND & ND \\
\hline
\end{tabular}


Table 47. Raw bacteria concentrations at the CSW component and the entire FCWQF treatment train for the fall event

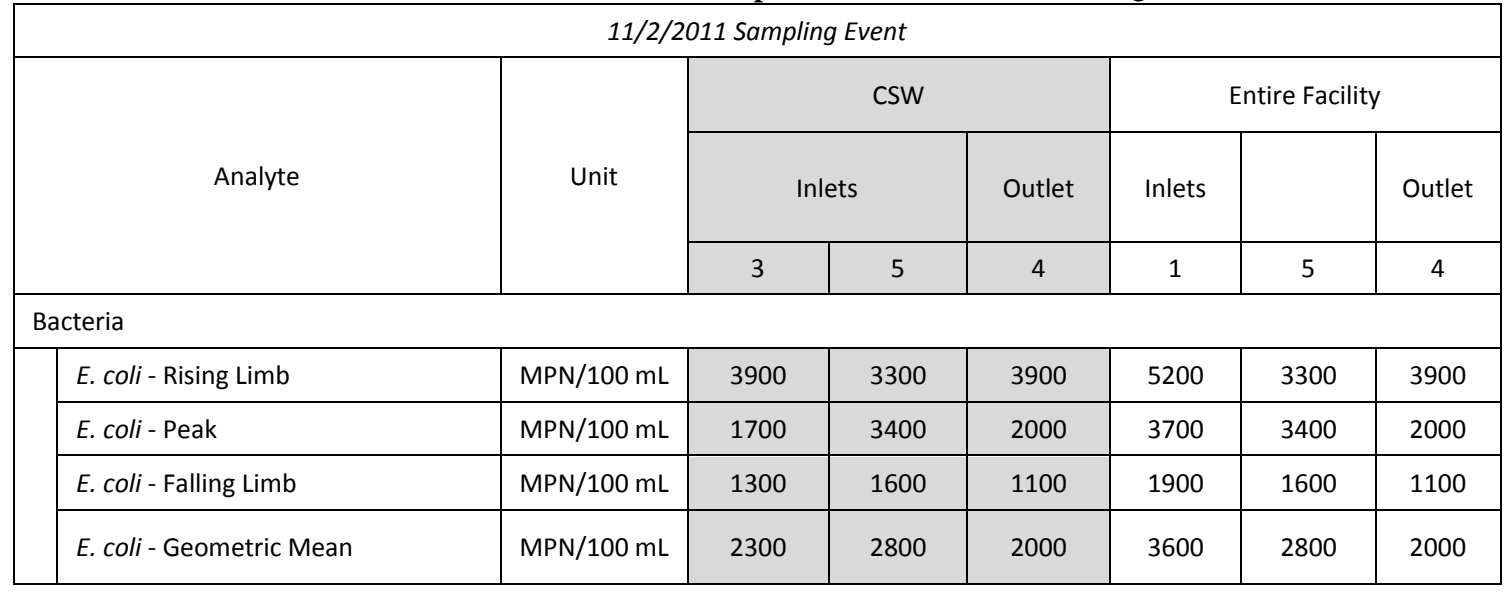

Table 48. Raw bacteria concentrations at the CSW component and the entire FCWQF treatment train for the spring event

\begin{tabular}{|c|c|c|c|c|c|c|c|}
\hline \multicolumn{8}{|c|}{ 3/5/2012 Sampling Event } \\
\hline \multirow{3}{*}{ Analyte } & \multirow{3}{*}{ Unit } & \multicolumn{3}{|c|}{ CSW } & \multicolumn{3}{|c|}{ Entire Facility } \\
\hline & & \multicolumn{2}{|c|}{ Inlets } & Outlet & \multicolumn{2}{|c|}{ Inlets } & Outlet \\
\hline & & 3 & 5 & 4 & 1 & 5 & 4 \\
\hline \multicolumn{8}{|l|}{ Bacteria } \\
\hline E. coli - Rising Limb & $\mathrm{MPN} / 100 \mathrm{~mL}$ & 770 & 960 & 550 & 800 & 960 & 550 \\
\hline E. coli - Peak & MPN/100 mL & 600 & 560 & 480 & 750 & 560 & 480 \\
\hline E. coli - Falling Limb & MPN/100 mL & 330 & -- & 170 & 500 & -- & 170 \\
\hline E. coli - Geometric Mean & $\mathrm{MPN} / 100 \mathrm{~mL}$ & 570 & 760 & 360 & 680 & 760 & 360 \\
\hline
\end{tabular}

